Portland State University

PDXScholar

\title{
Tephrostratigraphy of the middle Eocene Chumstick Formation, Cascade Range, Douglas County, Washington
}

Matthew John McClincy

Portland State University

Follow this and additional works at: https://pdxscholar.library.pdx.edu/open_access_etds

Part of the Geology Commons, Stratigraphy Commons, and the Volcanology Commons Let us know how access to this document benefits you.

Recommended Citation

McClincy, Matthew John, "Tephrostratigraphy of the middle Eocene Chumstick Formation, Cascade Range, Douglas County, Washington" (1986). Dissertations and Theses. Paper 3633.

https://doi.org/10.15760/etd.5501

This Thesis is brought to you for free and open access. It has been accepted for inclusion in Dissertations and Theses by an authorized administrator of PDXScholar. Please contact us if we can make this document more accessible: pdxscholar@pdx.edu. 
ABSTRACT OF THE THESIS OF Matthew John MCClincy for the Master of Science in Geology presented July 25, 1986. Title: Tephrostratigraphy of the middle Eocene Chumstick Formation, Cascade Range, Douglas County, Washington.

APPROVED BY MEMBERS OF THE THESIS COMMITTEE:
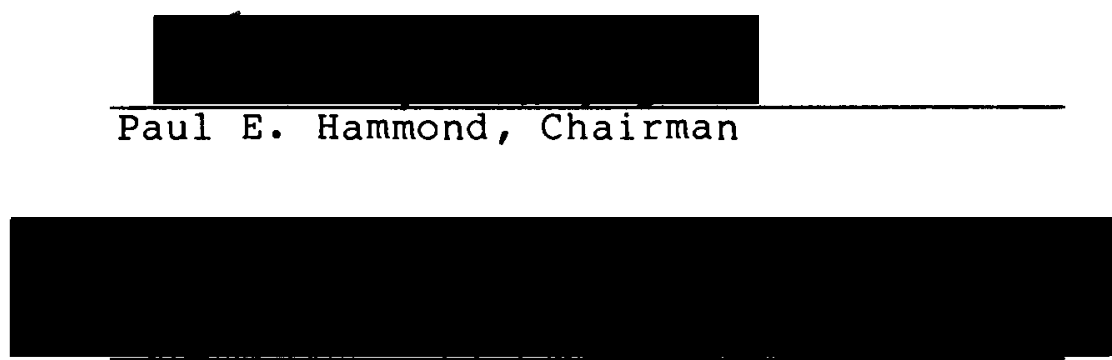

Marvin H. Beéson

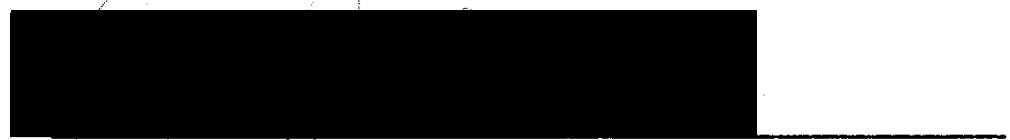

Ansel G.Johnson

This study outlines the ash (tuff) bed stratigraphy (tephrostratigraphy) in the middle Eocene Chumstick Formation of central Washington. The tuff beds provide local marker beds enabling interpretation of the stratigraphy and structure of the formation. The chemical signature of these units provides the basis on which the units can be traced over broad areas in the basin of deposition. Correlations of tuff beds were obtained over distances of $41 \mathrm{~km}$.

The tephrostratigraphy of the Chumstick Formation consists of nineteen tuff marker beds. Seventeen of these 
units are chemically characterized in this study. Ten elements were used to fingerprint these tuff beds. of these elements, step-wise discriminant analysis shows Sc to be the most discriminatory followed in decreasing order of ability to discriminate by Eu, Fe, Hf, Yb, La, Ta, Sm, Th, and U. Those units which have a distinctive chemistry can be easily identified, and they can be recognized inspite of having under gone mild alteration or containing minor detrital admixture.

Cluster analysis suggests that the Chumstick tuffs are from at least two chemically different volcanic sources. One group is relatively enriched in rare earth elements compared with the other, and relative amounts of $\mathrm{K}$ and Eu strengthens this division. 
TEPHROSTRATIGRAPHY OF THE MIDDLE EOCENE CHUMSTICK FORMATION, CASCADE RANGE, DOUGLAS COUNTY, WASHINGTON

by

MATTHEW JOHN MCCLINCY

A thesis submitted in partial fulfillment of the requirements for the degree of

MASTER OF SCIENCE

in

GEOLOGY

Portland State University

1986 
TO THE OFFICE OF GRADUATE STUDIES AND RESEARCH:

The members of the Committee approve the thesis of Matthew John McClincy presented July 25, 1986.
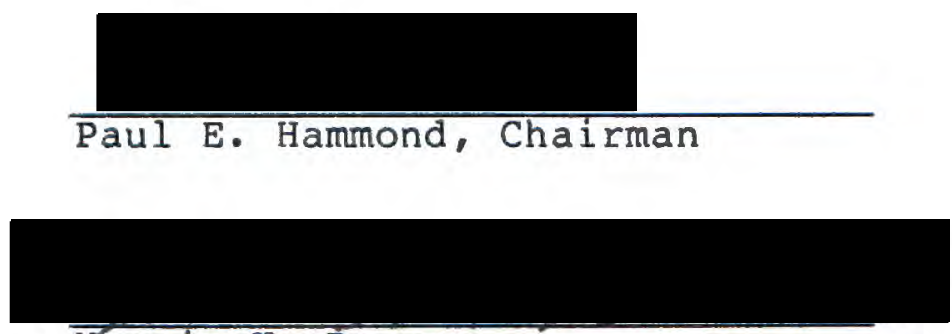

Marvin H. Beeson

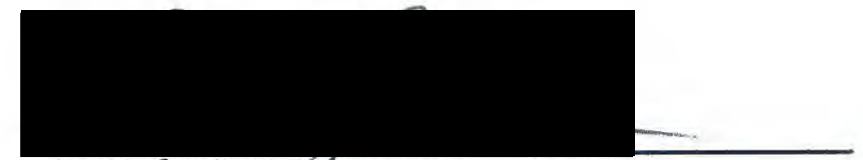

Ansel G. Jøhnson

APPROVED:

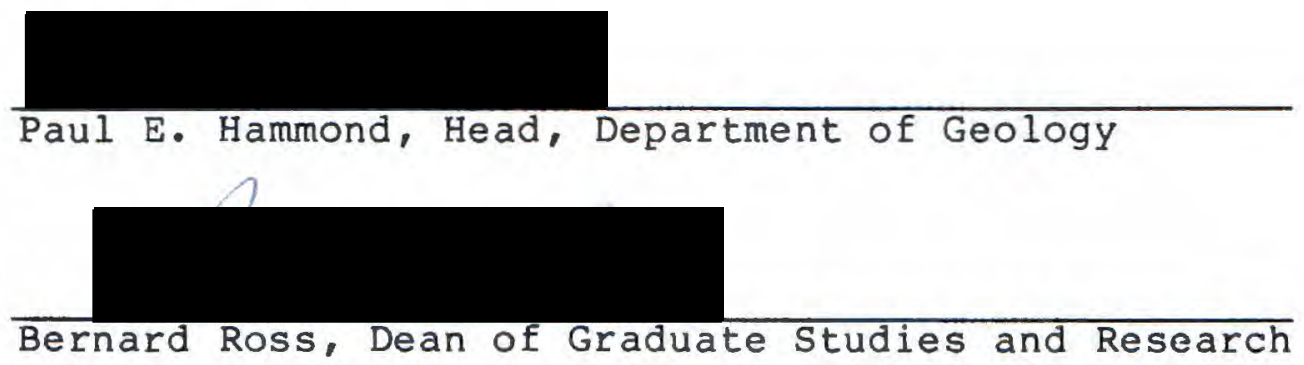




\section{ACKNOWLEDGMENTS}

I would like to express my thanks to the following parties: Dr. Paul E. Hammond for suggesting the project and for his advisement and encouragement; Ansel Johnson and Marvin Beeson for their advisement and support; Doug Gless, for his time and assistance in the field and laboratory, my brother Curt McClincy for his help in the field; the Academic Computer Services Department for their infinite patience; Jim Evans, for his fruitful discussions; Marathon Oil Company and Shell Western E\& P, Inc., for their financial support; Neil Woller for his time and use of his personal computer; and the state of Washington Division of Geology and Earth Resources for their technical support. All photographs which are not acknowledged in the subtitles were taken by the author. 
TABLE OF CONTENTS

PAGE

ACKNOWLEDGEMENTS • . . . . . . . . . . . . . . i i LIST OF TABLES • . . . . . . . . . . . . . . . . vi LIST OF PLATES . . . . . . . . . . . . . . . . . . vii LIST OF FIGURES • . . . . . . . . . . . . . . . . viii INTRODUCTION • . • • . . . . . . . • . . . . . . 1

Purpose and scope of investigation . . . . . . 1 Definition of a Tuff bed . . . . . . . . . . 2 Previous work . . . . . . . . . . . . . . . . 4 Methods . . . . . . . . . . . . . . . 5 GEOLOGIC SETTING • • • • • • • • • • • • • . 7

Geologic history . . . . . . . . . . . 7 Previous work . . . . . . . . . . . . . . 9 Local stratigraphy . . . . . . . . . . 10 TEPHROSTRATIGRAPHY OF THE CHUMSTICR FORMATION • • 15 Petrography of the Chumstick tuff beds . . . . 22 Diagenesis of the Chumstick tuff beds . . . . . 24 Geochemistry, methodologies of sampling and sample preparation . . . . . . . . . 25 DATA ANALYSIS . . . . . . . . . . . . . . . . 27 Step-wise Discriminant Analysis . . . . . . . 27 Discriminant Analysis . . . . . . . . . . 29 Cluster Analysis . . . . . . . . . . . 32 Graphical analysis . . . . . . . . . . . 34 
TABLE OF CONTENTS

PAGE

SOURCE AREAS FOR THE TUFFS . . . . . . . . . . 45 DISCUSSION . . . . . . . . . . . . . . 50 SUMMARY . . . . . . . . . . . . . 69 REFERENCES CITED . . . . . . . . . . . . . 73 APPENDIX A . . . . . . . . . . . . . 78

Step-wise discriminant analysis . . . . . 78 APPENDIX B . . . . . . . . . . . . . 80

Discriminant analysis... . . . . . 80 APPENDIX C . . . . . . . . . . . . . 83

cluster analysis . . . . . . . . . 83 APPENDIX D.................. . 85

$\mathrm{X}$-RAY DIFFRACTION PROCEDURES . . . . . . . 85 APPENDIX E . . . . . . . . . . . . . 86

Detailed stratigraphy of the individual tuff beds 86 Tuff of Fairveiw Canyon . . . . . . . 86 Yaxon Canyon tuffs... . . . . . . . 86 Tuffs of Mission Creek.......... . 90 Tuff of Eagle Creek . . . . . . . . . . 93 Clark Canyon tuffs... . . . . . . . 95 Tuffs of Sunitsch Canyon . . . . . . . 103 Tuffs of uncertain stratigraphic position . . 104 Tuff of East Mission Creek......... 104 Horse Lake Mountain tuffs . . . . . . 106 
TABLE OF CONTENTS

PAGE

Tuffs of Derby Canyon . . . . . . . . 106

Unnamed tuff beds . . . . . . . . . . 107

APPENDIX F . . . . . . . . . . . . . . . . . 119

Tables of sample location and sample chemistry 


\section{LIST OF TABLES}

Table

PAGE

I Nomenclature of Chumstick Tuffs . . . . . 19

II Petrography of the tuff beds . . . . . 23

II Step-wise Discriminant Analysis . . . . . 28

IV Canonical Discriminant Functions. . . . . 81

V Location of chemical samples. . . . . . 119

VI Chemistry of the Chumstick Tuffs. . . . . 121

VII Chemistry of the Chumstick Tuffs. • • . 122

VIII Chemistry of the Chumstick Tuffs. . . . . 123

IX Chemistry of stratigraphic Samples from tuffs Tcty 2 and Tcty........ . 124

$X$ Whole Rock Chemical Analysis of Five

Chumstick Tuffs............ 125

\section{LIST OF PLATES}

Plate

Location

1. Regional geologic map. . . . . . Back pocket

2. Summary table characterizing tuff beds Back pocket 


\section{LIST OF FIGURES}

FIGURE

PAGE

1. Generalized geology of the Chiwaukum graben in central Washington .. . . . . . . . 3

2. Stratigraphy columns for terranes within and on either side of the Chiwaukum graben 8

3. View of Chumstick Formation and Entiate Mountains . . . . . . . . . . . . 11

4. Chumstick Formation Tephrostratigraphy . . . 20

5. Tephrostratigraphy of the Chumstick Formation 21

6. Discriminant analysis scatterplot . . . . . 31

7. Cluster analysis dendrogram . . . . . . 33

8. Hf-Th-La/3 ternary plot . . . . . . . 35

9. Eu versus Hf plot of the Chumstick tuff beds - 36

10. Elemental Ratio Histograms for Tcth2, $\operatorname{Tcth} 3$, and $\operatorname{Tcty} 3$. . . . . . . . 38

11. Elemental Ratio Histograms for Tctc4, Tcte and Tctem ............. 39

12. Elemental Ratio Histograms for Tctc5 and Tct? 40

13. Chondrite-normalized plot of the rare-earth element concentrations in three analysis of Tcty 3 and one analysis of Tcth 2 and Tcth 3.42

14. Chondrite-normalized plot of the rare-earth element concentrations in four analysis of Tctc4 and two analysis of Tctem .. . . . 43

15. Chondrite-normalized plot of the rare-earth element concentrations in Tctc5 and Tct?. 
LIST OF FIGURES

Figure

PAGE

16. Possible Eocene Source Volcanics for the Chumstick Formation . . . . . . . 49

17. Tephrostratigraphy of the Chumstick Formation $\mathbf{5 2}$

18. Chondrite-normalized plot of the rare-earth element concentrations from tuff beds present in group $A$ of the cluster analysis dendrogram . . . . . . . . . . . 59

19. Chondrite-normalized plot of the rare-earth element concentrations from tuff beds present in group $B$ of the cluster analysis dendrogram.............. . 60

20. Eu versus $K$ plot for the Chumstick tuff beds present in group $A$ and group $B$ of the cluster analysis dendrogram. . . . . .

21. Eu versus Hf plot of Chumstick tuff samples and samples of sandstone from the Chumstick Formation. . . . . . . .

22. Diamictite portion of the tuff of Clark Canyon seven. . . . . . . . . . 97

23. Photomicrograph of the tuff of Clark

Canyon four showing the welding of glass shards around a lithic fragment . . .

24. Lense of pumice clasts present in the tuff of Clark Canyon two.......... 102

25. Photograph of the tuff of East Mission Creek dipping vertically and differentially weathering from the enclosing arkose . 105

26. Location map for figures 27-35 . . . . . 108

27. North $1 / 2$ Monitor Quadranglen . . . . . 110

28. SW 1/4 Cashmere Quadrangle. . . . . . . 111

29. NW 1/4 Monitor Quadrangle . . . . . . . 112

30. NW 1/4 Monitor Quadrangle... . . . . . 113 


\section{LIST OF FIGURES}

Figure

PAGE

31. N 1/2 Leavenworth Quadrangle . . . . . 114

32. E $1 / 2$ Leavenworth Quadrangle . . . . . 115

33. SE 1/4 Leavenworth Quadrangle. . . . . 116

34. N 1/2 Mission Creek Quadrangle . . . . . 117

35. S $1 / 2$ Monitor Quadrangle. . . . . . . 118 
INTRODUCTION

PURPOSE AND SCOPE OF INVESTIGATION

Volcanic ash beds preserved in basins of continental and marine sediments are potential stratigraphic marker horizons. This study examines the feasibility of using field criteria, petrography, trace element and rare earth element chemistry, supplied by Instrument Neutron Activation Analysis (INAA) as a means of characterizing and correlating devitrified tuff beds within a basin. The purpose is to develop a workable ash bed stratigraphy for an individual basin. Continental basin analysis would particularly benefit from this type of study because microfossils are not present to furnish stratigraphic control. The ability to establish a refined tephrostratigraphy within an otherwise homogeneous sequence of sediment would provide stratigraphic control necessary for structural interpretations and lateral correlations of equivalent and different facies. Regional tephra correlations offer a stratigraphic control that is currently unavailable by absolute age dating, or identification of faunal or floral assemblages.

This study focuses on tuff beds preserved in continental sedimentary rocks of the Chumstick Formation of middle Eocene age located in central Washington (Figure 
1). In order to characterize these units, field characteristics, petrography and chemical data were collected for each individual tuff bed. Based on this data, attempts were made to define a signature for each bed. This signature enables individual tuff beds to be recognized and distinquished from one another, thereby establishing a useful tephrostratigraphy for the Chumstick Formation.

DEFINITION OF A TUFF BED

Tuff beds are consolidated preserved deposits of volcanic ash size ejecta (Fisher and Schmincke, 1984). This ash is composed of glass, crystals, pumice and lithic fragments. These deposits occur either as ash-falls or ash-flows. Ash falling from the tephra cloud, after ejection from a volcanic vent, mantles the topography around the vent and down wind. Ash-flows can originate in different ways. They can develop by a direct blast or dome collapse, boiling over of highly gas-charged magma from a vent, or the collapse of vertical eruption column (Fisher and Schmincke, 1984). The ash-flow moves outward from the volcano following topographic lows. Subsequent terrestrial processes act on the tephra blankets eroding, transporting, thickening and burying the tephra. To the stratigrapher, a tuff bed which is preserved in the stratigraphic record represents a widespread, thinly bedded 

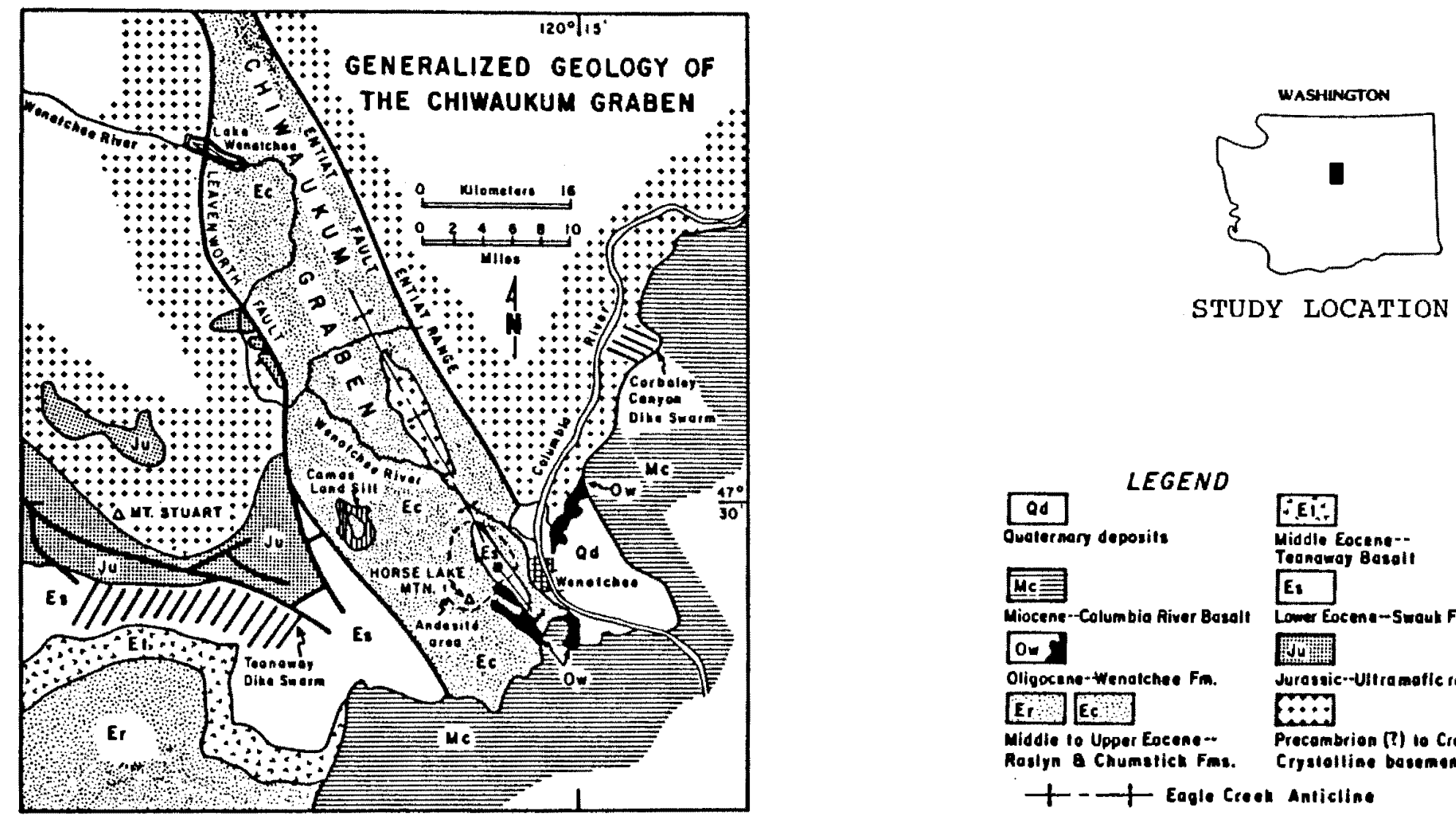

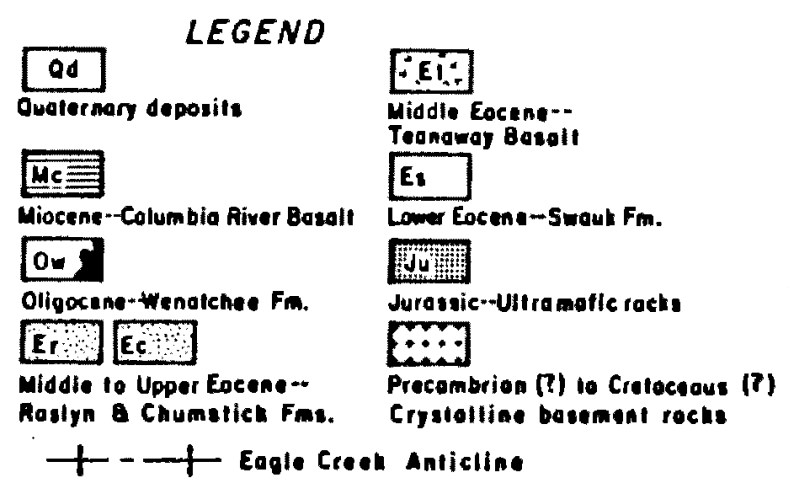

Figure 1. Generalized geology of the Chiwaukum graben in central Washington (after Gresens, 1983). 
time horizon which was created in a matter of a few hours to a few days.

PREVIOUS WORK

The use of tuff beds for stratigraphic control has long been recognized by geologists. Early studies of bentonites utilizing field criteria and petrography yielded encouraging results. Rosenkrans (1936), on the basis of megascopic lithologic criteria, successfully correlated several Ordovician "metabentonites" over a distance of $322 \mathrm{~km}$ in south-western Virginia. Utilizing mineralogic composition and electric log subsurface data, slaughter and Earlyey (1965) developed an upper Cretaceous bentonite stratigraphy in north-central Wyoming. They were able to correlate bentonite beds across lithologic facies over distances of $260 \mathrm{~km}$.

Chemical fingerprinting of tephras has been successfully used by Powers and Malde, (1961); Borchardt and others, (1971); Kittleman and others, (1971); Izett and others, (1972); Borchardt and others, (1973); Westgate and Fulton, (1975); SarnaWojcicki, (1976); Sarna-Wojcicki and others, (1979); and Sarna-Wojcicki, (1984) to distinquish, trace, and correlate younger Cenozoic units. The chemical analysis of volcanic glass (Borchardt, 1971) has become a standard technique in the characterization 
of tephras. Characterization of tephras based on the chemistry of the glass fraction is not faced with the potential problems of winnowing and preferential composition of heavy mineral grains with distance from the vent.

METHODS

Field criteria, petrography and trace and rare earth element chemistry were collected to define individual tuff beds in order to develop the Chumstick tephrostratigraphy. All possible lines of evidence should be considered when attempting correlations with tephras or their altered products. Although helpful in identifying tuff beds, field characteristics of individual beds, such as color and thickness, are not always consistent and may not provide distinctive criteria by which multiple tuff beds can be distinguished. Primary pyroclastic minerals are not readily distinguishable from admixed detrital minerals. Deposition of the Chumstick tuff beds in a fluvial environment of coarse-grained arkosic sand only exasperates this problem. Refinements in geochemical techniques offer a means of distinguishing and correlating lithologically similar volcanic ash beds in structurally complex terranes; consequently, the chemical properties of the Chumstick tuff beds will be emphasized in this study . 
Because tephras of Eocene age are normally devitrified, entire samples without any separation of components (bulk samples) were employed to establish chemical signatures for the individual tuff beds. Huff (1983) has shown that bulk analysis of altered pyroclastic material is a viable method for correlation work on a regional scale. The mobilization of trace elements in volcanic ash during alteration is not well understood at this time. But, as Huff (1983) points out "the uncertainty about alteration effects does not preclude the use of composition as a stratigraphic tool, provided the existing compositional variation can be carefully documented."

It may be possible through extensive laboratory procedures, i.e., magnetic separation and heavy liquid separation to extract a fraction of the devitrified Chumstick tuffs which represents the glass portion of the tephra. The chemistry of this separate would in all likelihood provide a much smaller chemical variance between samples of the same bed than would the chemistry of bulk samples. However, the alteration and diagenesis of tephras in other Eocene basins which will be compared with the tephrostratigraphy in this study may not be the same. It is hoped that the different diagenetic conditions present in other basins, which may have preserved the tephra, does not alter the chemistry enough to preclude its use in making or attempting correlations. 


\section{GEOLOGIC SETTING}

The Chumstick Formation is confined to the Chiwaukum graben except for a few small exposures east of the graben (Gresens, 1983). Figure 1 shows the generalized geology of the Chiwakum graben, and Figure 2 shows the regional stratigraphy. The graben is on the east flank of the Cascade Range. It is bounded on the west by the Leavenworth fault and on the east by the Entiat fault. Precambrian(?) to Cretaceous(?) crystalline rocks border the graben on the east and northwest. Lava flows from the Miocene Columbia River basalt overlie the Tertiary rocks of the southern portion of the graben and adjacent units. Early to middle Eocene rocks are present southwest of the graben and oligocene sedimentary rocks are preserved in the southern part of the graben and east of Wenatchee.

\section{GEOLOGIC HISTORY}

The genesis of the Chiwaukum graben as a structure occurred about $46(?)$ million years before present (m.y.b. p.) according to Gresens $(1982 a)$. He suggests two possible structural models for its inception. Model one involves the clockwise rotation of the terrain west of the Leavenworth fault and simultaneous strike-slip movement along the Entiat fault creating a wedge shaped opening * 
STRATIGRAPHY

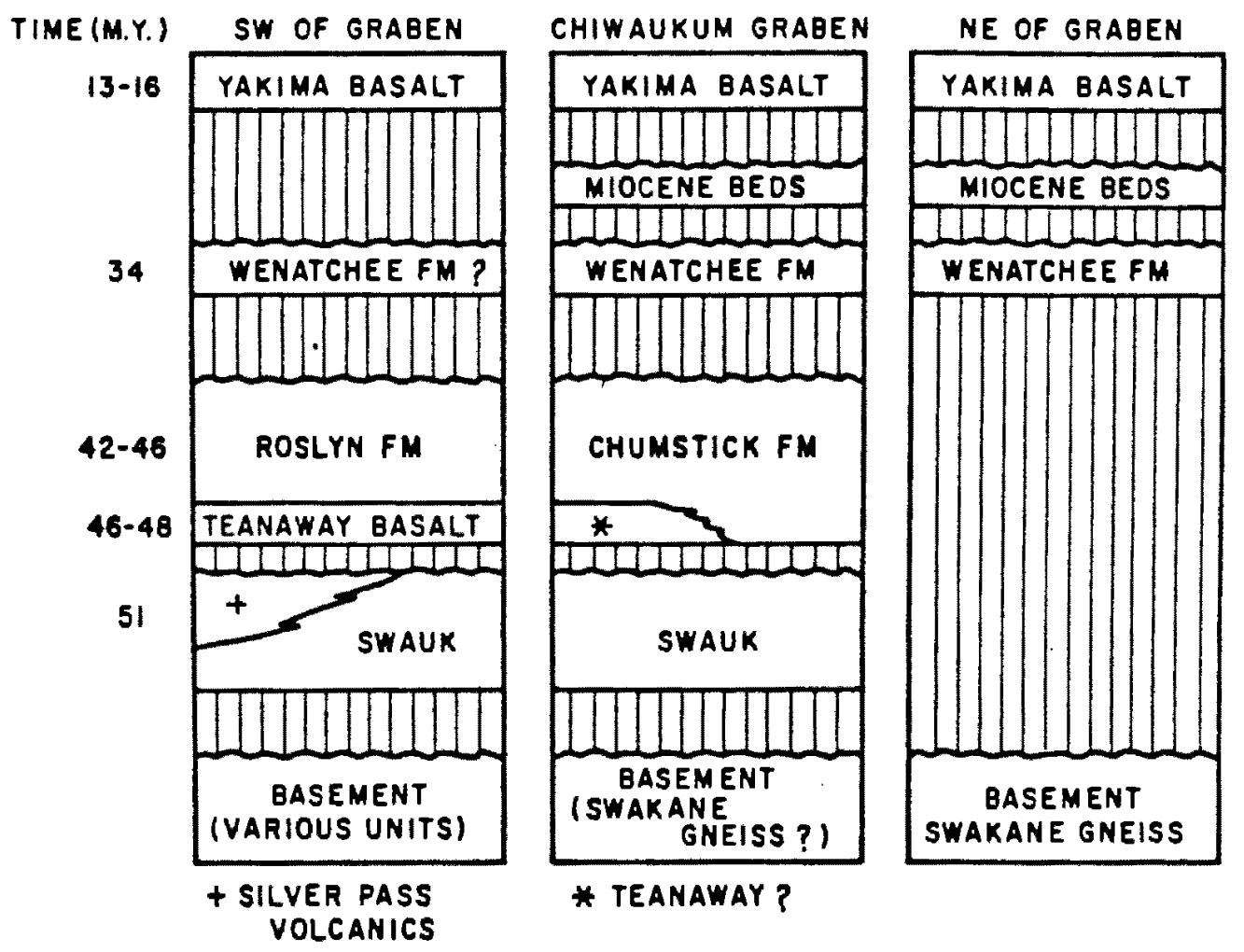

Figure 2. Stratigraphic columns for terranes within, and on aither side of, the Chiwaukum graben (after Gresens, 1983). 
The second model a "rhombochasm" (Carey, 1958) or a pull apart basin (Crowell, 1974) requires no rotation. It involves strike-slip motion along a fault which has a "kink" in it. As the basin opened, coarse grained feldspathic sediments derived from the northeast (Buza, 1979) rapidly accumulated. Infrequent volcanic ash-falls and ash-flows were deposited with the sedimentary rocks.

Development and sedimentation of the Chumstick basin ended about $40 \mathrm{~m} \cdot \mathrm{Y} \cdot \mathrm{b} \cdot \mathrm{p}$. This was followed by 5 to $6 \mathrm{mil-}$ lion years of quiesence and erosion (Gresens, 1982). During the early oligocene, $34 \mathrm{~m} \cdot \mathrm{y} \cdot \mathrm{b} \cdot \mathrm{p} \cdot$, renewed tectonic activity generated sedimentation which created the wenatchee Formation. Deformation of the graben by northeastsouthwest compressive stress occurred between 34 and 29 m.y.b.p. At approximately $30 \mathrm{~m} \cdot \mathrm{y} \cdot \mathrm{b} \cdot \mathrm{p} \cdot$, the Horse Lake Mountain intrusive complex was emplaced. The Columbia River basalts, probably flowed over the sedimentary deposits of the graben during the middle Miocene (16.5 to 14.5 m.y.b.p.l. They were later eroded during the uparching of the area in the formation of the Cascade Range (Gresens, 1982).

\section{PREVIOUS WORK}

The sedimentary rocks of central washington were first described by Russell (1900); he interpreted that 
two distinct units were present besides the Rosyln sandstone which occurs southwest of the Chiwaukum graben. He named these two units the Camas sandstone and the Wenatche sandstone. Smith (1904) formally named the sedimentary sequence the Swauk Formation and felt the sandstones within the graben and along its southwest margin were deposited in a single Tertiary lake or estuary. Waters (1930), Chappell (1936), Page (1939) and Willis (1950) continued to interpret and extend the boundaries of the Swauk Formation. Detailed mapping of the sedimentary rocks has been completed by Willis, (1903); Alexander, (1956); Lupe, (1971); Laravie, (1976;) Whetten, (1980, 1980a); Whetten and Laravie, (1976) and Whetten and Waitt, (1978). On the basis of fission track ages obtained from interbedded tuffs, Gresens and others (1981) formally proposed the creation of the Chumstick Formation and Wenatchee Formation which were previously considered part of the older Swauk Formation. Jim Evans is currently studying the sedimentation of the Chumstick formation as a doctoral dissertation at the University of Washington.

\section{LOCAL STRATIGRAPHY}

The Chumstick Formation (Figure 3) occurs almost entirely in the Chiwaukum graben with minor occurrences to the east (Gresens, 1983). The following general des- 


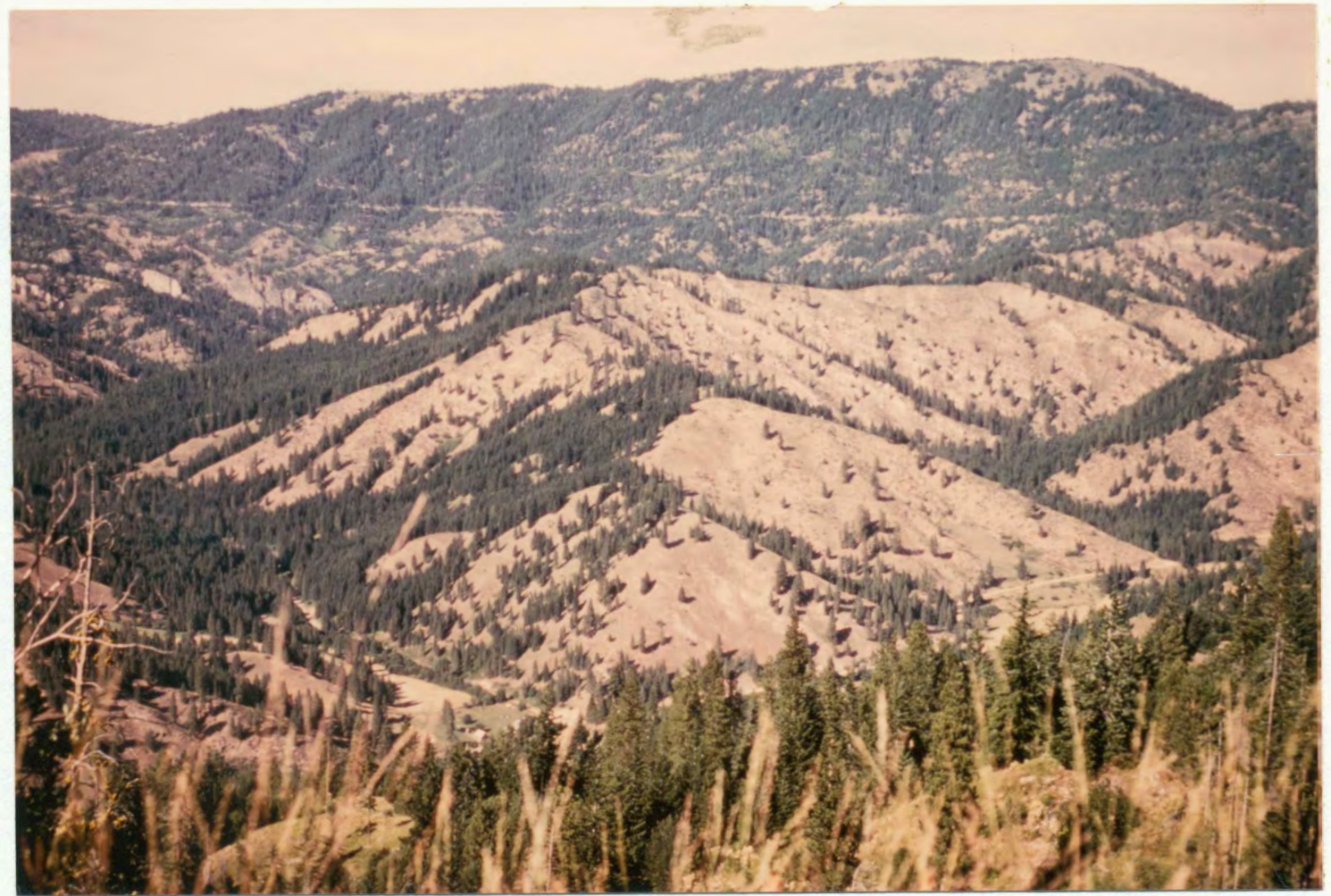

View looking north, from the center of section 23 T25N., R.18E., toward the Entiat Mountains. The Entiat fault separates the Chumstick Formation, foreground, from the Swakane Biotite Gneiss. The road cut which runs across the upper one quarter of the photograph follows approximately the trace of the Entiat fault (Photo by P.E. Hammond, 1984).

Figure 3. View of Chumstick Formation and Entiat Mountains. 
cription of the Chumstick Formation is from Gresens (1983,

p.7) and is based on Whetten's description, in Gresens and others (1981), of the formation.

The Chumstick Formation is a thick section of interbedded sandstone, shale, and conglomerate that range from fluvial to lacustrine. The most common lithologies are sandstone, pebbly sandstone, and conglomerate, which occur together in massive beds. Shale is less abundant except in the Nahahum Canyon Member, which is designated as a separate facies. Clasts in the conglomeratic and pebbly beds include foliated metamorphic rocks, felsic volcanic rocks, and vein quartz in various proportions. The sandstones are feldspathic, biotite rich, and reflect the same generally gneissic source terrane as the conglomerates. The sandstone is locally zeolitized with laumontite and, less commonly, clinoptilolite. Sedimentary structures of fluvial origin include imbrication in conglomerates, graded, cross-bedded, and channeled sandstone, rare ripple marks and flute casts, and organic remains such as leaves, branches, and logs. Minor coal seams and lenses occur locally.

Shale and shaly sandstone dominate the lithology of the uppermost part named the Nahahum Canyon Member of the Chumstick Formation. This member is interpreted by Gresens (1981) to be a lacustrine facies reflecting the final filling of the graben.

More recent work by Evans (1986) recognizes three phases of basin development. Phase one sedimentation occured as a rapidly aggrading alluvial braid plain within a half graben which Evans informally names the "Western sub-basin". Sediment transport direction was from $E$ to NW-SW. All of the tuff beds in the Chumstick Formation were deposited with phase one sediments. The continuous preservation of the tuff beds over many kilometers sug- 
gests a paleotopography of low relief which would support this sedimentaion model. Phase two sedimentation filled an "Eastern sub-basin" with lacustrine sediments. Mixedload fluvial deposits unconformably overlie phase one sediments in the southern portion of the basin. Anastomosed and mixed-load fluvial deposits make up the third phase of Chumstick sedimentation. These deposits disconformably overlie phase one and two deposits in the northern part of the basin. Phase three sediments and the lacustrine zone of phase two are equivilant to the sediments referred to by Gresens (1981) as the Nahahum Member. Sediments of the "Western sub-basin" dip steeply to the northwest in a homoclinal sequence. Chappell (1936) initially recognized that this homoclinal sequence was stratigraphically over 9,100 meters thick. He speculated that the thickness may be the result of isoclinal folding. Gresens (1983, p.55) points out that no overturned bedding has been observed, and that the tephrostratigraphy in the basin indicates that the Chumstick is indeed a thick sequence of arkosic sandstone. Local overturned bedding is found associated with a fault zone bounding the Swakane Biotite Gneiss inlier (Evans, personel communication, 1986). However, this study finds no repetition of tuff beds; thus discounting the possibiity of significant thickening of the sequence by faulting. Measured sections and map projections between tuff beds indi- 
cate a conservative stratigraphic thickness of $8,700 \mathrm{~m}$ between the tuff of Fairview Canyon, which is the oldest tuff bed, and the tuff of Sunitsch Canyon one which is the youngest tuff bed.

The Chumstick Formation nonconformably overlies the Swakane Biotite Gneiss, and is in turn unconformably overlain by the oligocene Wenatchee Formation. 
TEPHROSTRATIGRAPHY OF THE CHUMSTICK FORMATION

The tuff beds preserved in the Chumstick Formation are the major marker horizons present. Faults are mapped based on their stratigraphic offsets. Tuff beds outline folds along the western margin of the graben, and they indicate stratigraphic levels which are otherwise difficult to follow in the repetitious sequence of sandstone. The Chumstick tuffs include both ash-fall and ashflow deposits which range in thickness from $30 \mathrm{~cm}$ to 19.5 m. Based on five whole rock analyses, the tuffs are rhyolitic ranging from 76.27 to 79.44 percent $\mathrm{SiO}_{2}$ (Table $x)$. The tuff beds have been diagenetically converted to chert. In outcrop and hand specimen, the tuffs are olive-grey on fresh surfaces and weather white. The color is the result of zeolitization of the tuff to clinoptilolite (Gresens, 1981). They break with a subconchoidal fracture, and pale pink stilbite is commonly present on fracture faces. The tuff beds are more resistant to erosion than the enclosing arkosic sandstones and commonly uphold small ridge crests or rims along lower ridge slopes. The immediately overlying sandstone bed is similarily resistant to erosion probably resulting from upward migration of silica from the tuff. These characterstics make these tuff beds excellent field marker horizons. Vegetation does not cover the tuffs, and float from them is distinguishable from the sandstone. 
A chert bed can be recognized as a tuff in the field by its sharp basal contact, the presence of pumice clasts, crystals, lithic and carbon fragments. Chumstick tuffs which are interpreted to be ash fall deposits are fine grained at their base and increase in detrital sand content toward their top eventually grading into a tuffaceous sandstone. Shallow trough cross-bedding above the basal fine grained zone and the presence of detrital sand indicates fluvial reworking of the ash. Scattered rounded pumice lapilli commonly are present and may be fluvially concentrated in thin lenses.

Those units which are interpreted to be of an ashflow genesis commonly exhibit sharp basal and top contacts. Angular pumice clasts and lithic and carbon fragments are common constituents. Other criteria exhibited are a lithic clast rich basal zone, deflation or flow structures around lithic fragments, a massive lower portion overlain by lenses of reversely graded material and a fine grained vitric horizon capping the flow (Sheridan, 1979). The presence of tuff beds in the Chumstick Formation was first noted by waters (1930). However, Page (1939) initially recognized the importance of these units to the local stratigraphy.

Water-laid tuff occurs at a few horizons. Some of the tuff strata are laterally so persistent that they make the best "key bed" in the entire formation, being tracable intermittently for 13 $1 / 2$ miles from the mouth of olalli Canyon to the mouth of the Little Chumstick. 
This tuff has since been named the Tuff of Eagle Creek, (Gresens, 1977) and is one of the main marker beds within the Chumstick Formation. As detailed geologic mapping progressed in the Chiwaukum graben, the tephrostratigraphy of the Chumstick Formation developed. This tephrostratigraphy can be followed in whetten $(1980,1980 a)$, whetten and Laravie (1976), whetten and Waitt (1978), Tabor and others (1982) and most recently Gresens (1983).

Before this study, ten tuff beds and two tuffaceous sandstone horizons with established stratigraphic position were recognized in the Chumstick Formation. This study adds six more tuff beds to the known tephrostratigraphy of the formation. Five tuff beds of uncertain stratigraphic position and sixteen tuff beds of known stratigraphic position are the focus of this study.

The nomenclature for the Chumstick tuffs used by Gresens (1983) is adopted for use in this study. The tuffs are labeled "Tct" for "Tertiary Chumstick tuff". Letter codes are added to identify those tuffs which outcrop in geographic localities. For example, there are two tuff beds which outcrop in Sunitsch Canyon. These are labeled Tctsl and Tcts2. Numbers are added to the label when more than one unit is present in a section. The tuff beds are numbered in descending stratigraphic order. This convention holds true for each stratigraphic section except for the tuffs of Mission Creek Tctm2 and 
Tctml. These have been reversed so that Tctm2 is younger than Tctml.

Table I shows the name of each tuff bed, the nomenclature used for them in this paper and that used by previous workers. Figures 4 and 5 display the stratigraphy of the Chumstick tuffs, the approximate stratigraphic distances between them, and the known age dates. Plate 1 shows the geology of the Chiwaukum graben region and the exposures of the Chumstick Formation tuff beds. Plate 2 summarizes the characteristics of the Chumstick tuff beds. 


\section{NOMENCLATURE OF THE CHUMSTICK TUFF BEDS}

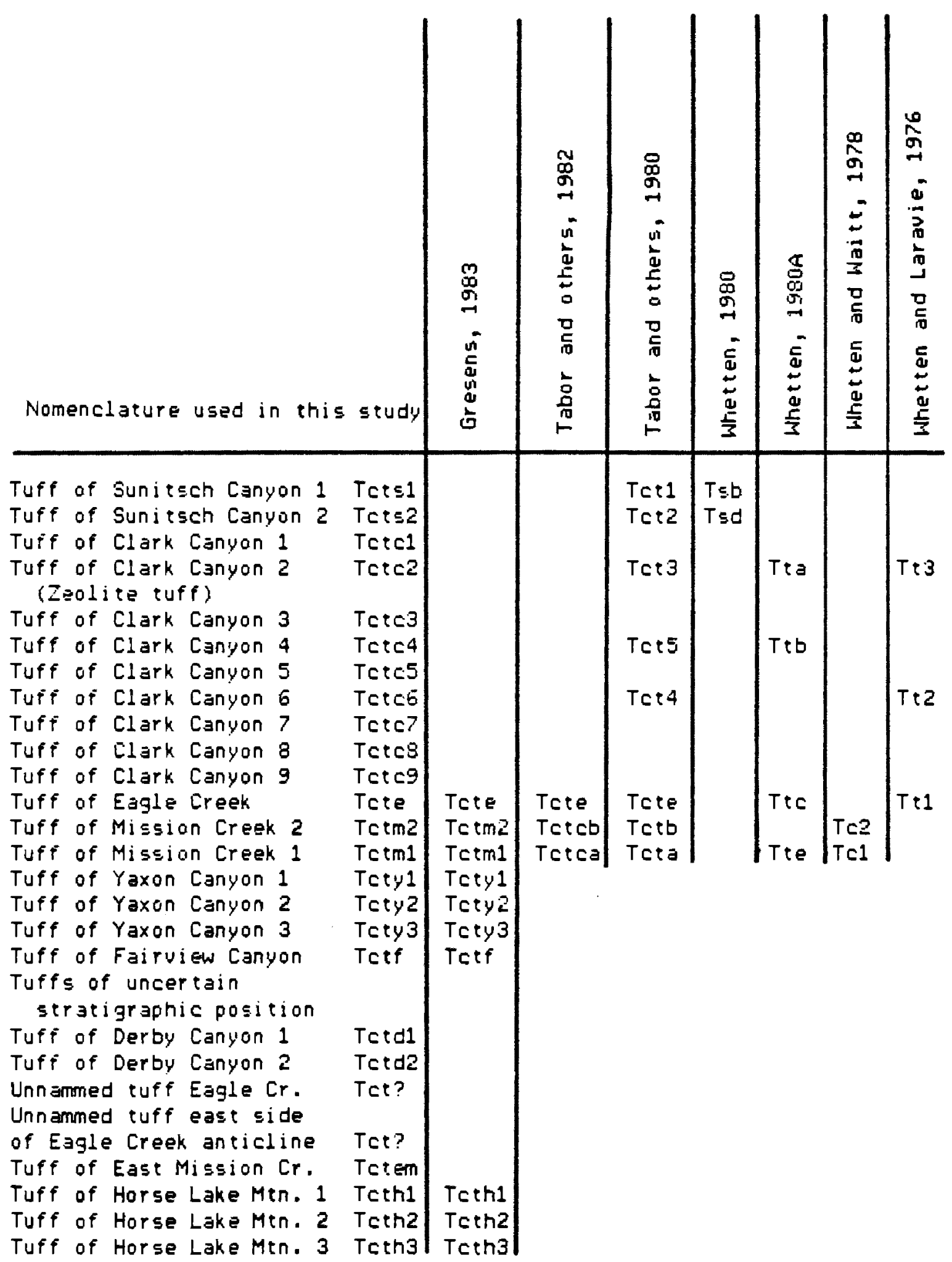


CHUMSTICK FORMATION TEPHROSTRATIGRAPHY

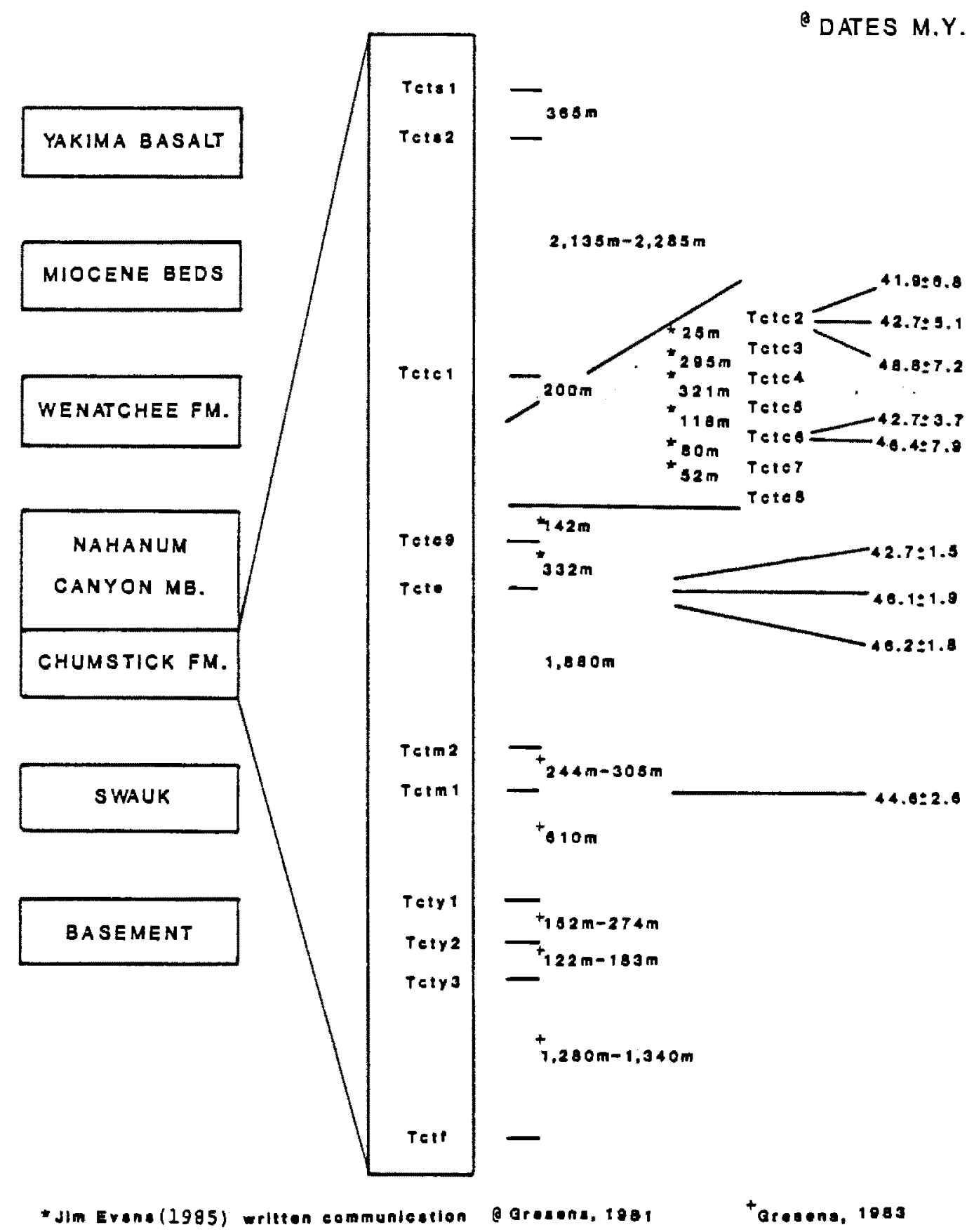

Figure 4. Chumstick-Formation tephrostratigraphy 
TEPHROSTRATIGRAPHY

OF THE CHUMSTICK FORMATION

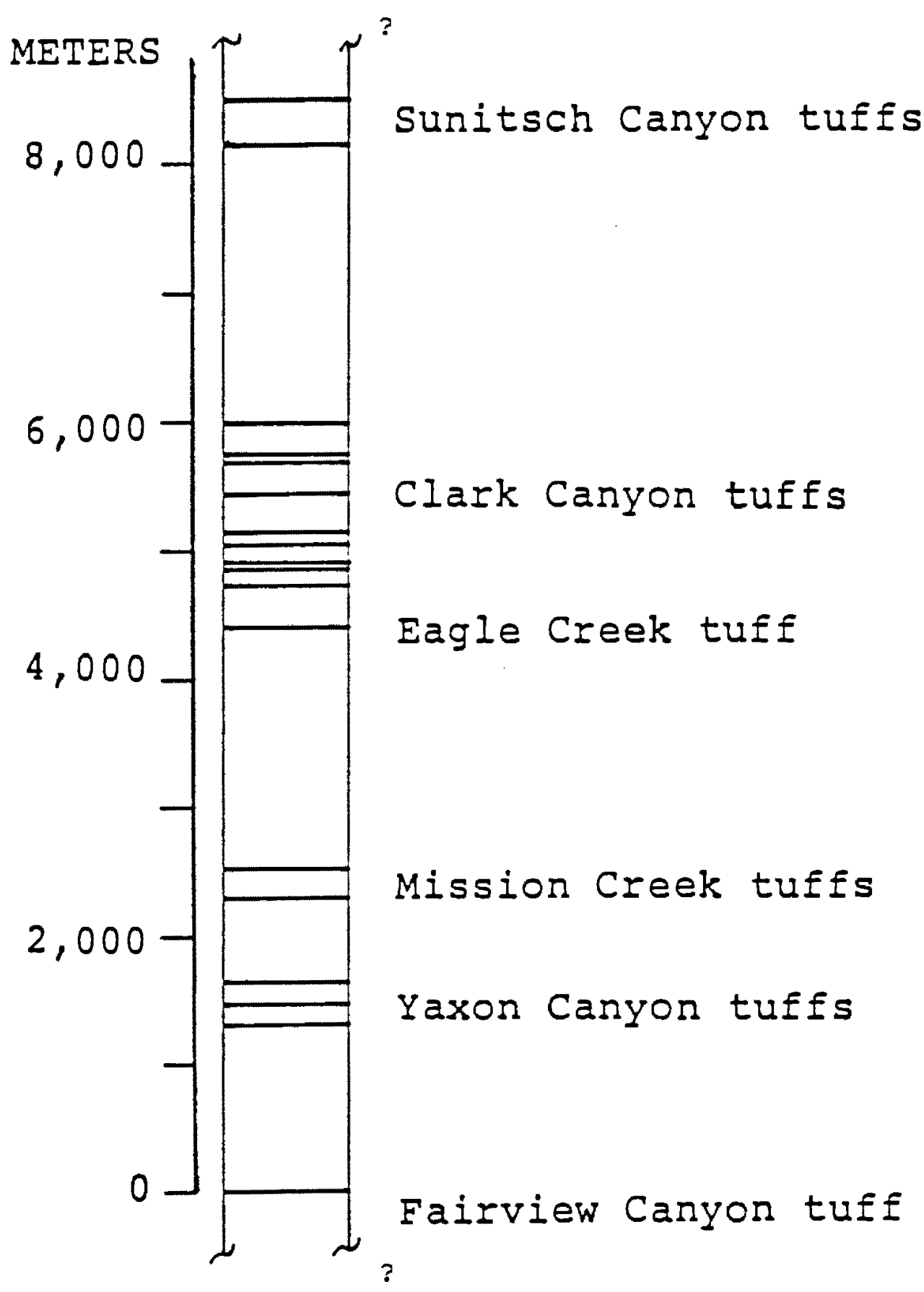

SOURCES: Evans 1985, Gresens 1983

Figure 5. Tephrostratigraphy of the Chumstick Formation 


\section{PETROGRAPHY OF THE CHUMSTICK TUFF BEDS}

One to seven thin sections were studied for each tuff bed. This study clearly shows the pyroclastic genesis of the Chumstick tuff beds. Clues for the identification of primary pryoclastic minerals used were: a) presence of minerals in pumice clasts, b) euhedral minerals, and c) embayed crystals. Welding of glass shards seen in thin section was considered evidence for ash-flow origin of the bed.

Identification of suites of accessory minerals present in the chumstick tuff beds is hampered by the ability to discern primary pyroclastic minerals from detrital minerals. Deposition in a fluvial environment where the ash beds are interstratified with arkosic sandstones resulted in mixing of pyroclastic and non-pyroclastic detritus. None of the Chumstick tuff beds are totally free of detritus. Observed detritus included muscovite, biotite, feldspar, quartz and lithic fragments. In most units this detritus was less than 1 of of the total material present. However, the percentage of pyroclastic crystals present is only approximately 2 to $3 \%$. Thus, it was not possible to confidently identify suites of accessory minerals for all of the beds. The units whose accessory minerals could not be confidently identified are Tctc3, Tctc6, Tctc7, Tctc8, Tctc9, Tcthl and Tctf. Tctcl 
and Tctc5 were too altered to identify the crystals present. The presence of detrital admixture did not preclude the ability to chemically characterize the tuff beds (see graphical analysis section). Table II lists the minerals identified in the Chumstick tuff beds.

TABLE II

PETROGRAPHIC CHARACTERISTICS

OF THE CHUMSTICK TUFF BEDS

TUFP BED MINERALS

Tctc2 Sanidine

Tctc4 Sanidine, zircon, Hornblende, Plagioclase

Tcte R-spar, Sanidine, Zircon

Tctm2 Biotite, Sanidine, Zircon, Hornblende

Tctml Sanidine, Apatite, Hornblende

Tctyl Sanidine

Tcty 2 Sanidine, zircon, Magnetite ( 3 )

Tcty 3 Sanidine, Apatite

Tcth2 Apatite

Tcth3 Apatite

Tctem Clino-pyroxene, Hornblende, Sanidine, Zircon 


\section{DIAGENESIS OF THE CHUMSTICK TUFF BEDS}

In this study $x$-ray diffraction of the Chumstick tuffs indicates that the tephra has been diagenetically altered to a quartz clinoptilolite or heulandite, smectite assemblage. Procedures followed are described in Appendix D. This assemblage is consistant with that reported by Iijima and Tada (1981). They recognized three silica diagenetic zones for acidic volcaniclastic sediments: amorphous silica (volcanic glass) ---> low cristobalite $-\rightarrow$ quartz. Since the cation population present in the volcanic glass does not fit into the cristobalite or quartz lattices, zeolites are also formed during diagenesis of the glass. Iijima and Tada did not discuss the quartz zone. However, the minerals associated with low cristobalite are montmorillonite and glass shards filled with high silica zeolites such as clinoptilolite and mordenite. They concluded that the progressive ordering of the silica is affected by geothermal temperature, not by overburden pressure. Later work by Kano and Taquchi (1982) and Kano (1983) agreed that the ordering process is controlled mainly by temperature and to some extent by chemical conditions.

Preliminary results from a vitrinite reflection study on the Chumstick Formation yielded Ro values ranging from .596 to .763 which indicate paleo-burial temperatures 
of 119.2 to $151.9^{\circ} \mathrm{C}$ (Bill Phillips, 1985, written communication).

Recently Crerar and others (1985) stated that the progressive ordering of $\mathrm{SiO}_{2}$ is a consequence of the variation of silica polymorph solubility with surface area and surface-face energy. Thus, the progressive ordering of amorphous glass to quartz, the most stable silica form, is a thermodynmic reaction. The reaction would proceed independent of temperature although temperature does serve to speed up the reaction.

\section{GEOCHEMISTRY, METHODOLOGIES}

OF SAMPLING AND SAMPLE PREPARATION

Nineteen trace, rare earth and major elements were determined by instrumental neutron activation analysis for Chumstick tuff bed samples. Samples were taken from the bottom $10 \mathrm{~cm}$ of each tuff bed because this part of the bed shows the least reworking and admixture of detritus. Additional samples were taken 0.5 to $17 \mathrm{~km}$ apart from the same tuff beds that had been traced in the field (see Plate 1, see Table V and Figures 29-37 for sample locations and Tables VI-VIII for data). Samples were also taken at narrow statigraphic levels through tuff Tcty 3 and in two locations of tuff Tcty 2 to determine chemical variability within the tuff and to examine effects of detrital admixture (see Table IX). Samples were 
not taken from the tuffaceous sandstone horizones Tctsl and Tcts 2 because of the extensive reworking of the units. The samples were crushed in a jaw rock crusher with hardened steel plates. Sixteen grams of each sample were next powdered in a steel mortar and pestle, and sieved through a 60 mesh screen. One gram was quartered and placed in a polyethelene vial. These samples were irradiated for one hour with a flux of $2 \times 10^{12} \mathrm{n} / \mathrm{cm}^{2}$ second in a TRIGA reactor at Reed College, Portland, Oregon. International reference standard BCR-1 (resampled from original locality) was used. Gamma ray counts were determined on a TN-4000 Tracor Northern, which uses a lithium drifted germanium crystal detector at Portland State University. 


\section{STATISTICAL ANALYSIS}

Three statistical methods were used to evaluate the chemical contents of the Chumstick Formation tuff beds. Step-wise discriminate analysis (Nie and others, $1975)$ was used to determine which elements provided the best discrimination. Discriminant analysis, a second program, (Nie and others, 1975) was used to correlate some exposures of tuff beds of uncertain stratigraphic position with members of the established stratigraphy in the basin. Cluster analysis (Davis, 1973) was used to group similar samples of tuff beds together and to check the correlations made by discriminant analysis.

\section{STEP-WISE DISCRIMINANT ANALYSIS}

Table III lists the results of the step-wise discriminant analysis (Appendix A). Seventeen of the nineteen elements are ranked in their order of ability to discriminate between the Chumstick tuffs. Of these, ten elements were choosen for use in the following discriminant and cluster analysis. Listed in decreasing order of ability to discriminate between the tuff beds they are; Sc, $\mathrm{Eu}, \mathrm{Fe}, \mathrm{Hf}, \mathrm{Yb}, \mathrm{La}, \mathrm{Ta}, \mathrm{Sm}, \mathrm{Th}$, and U. 
Table III

SUMMARY TABLE

\begin{tabular}{|c|c|c|c|c|}
\hline \multirow[b]{2}{*}{ STEP } & \multicolumn{2}{|c|}{ ACTION } & \multirow{2}{*}{$\begin{array}{c}\text { VARS } \\
\text { IN }\end{array}$} & \multirow{2}{*}{$\begin{array}{l}\text { WILKS ' } \\
\text { LAMBDA }\end{array}$} \\
\hline & ENTERED & REMOVED & & \\
\hline 1 & Sc & & 1 & 0.036901 \\
\hline 2 & $\mathrm{Eu}$ & & 2 & 0.002188 \\
\hline 3 & $\mathrm{Fe}$ & & 3 & 0.000295 \\
\hline 4 & $\mathrm{HE}$ & & 4 & 0.000043 \\
\hline 5 & $Y b$ & & 5 & 0.000008 \\
\hline 6 & $\mathrm{La}$ & & 6 & 0.000002 \\
\hline 7 & $\mathrm{Ta}$ & & 7 & 0.000000 \\
\hline 8 & Co & & 8 & 0.000000 \\
\hline 9 & $\mathrm{Cs}$ & & 9 & 0.000000 \\
\hline 10 & $\mathrm{Sm}$ & & 10 & 0.000000 \\
\hline 11 & $\mathrm{Cr}$ & & 11 & 0.000000 \\
\hline 12 & $\mathrm{Na}$ & & 12 & 0.000000 \\
\hline 13 & $\mathrm{Ba}$ & & 13 & 0.000000 \\
\hline 14 & $\mathrm{~K}$ & & 14 & 0.000000 \\
\hline 15 & Th & & 15 & 0.000000 \\
\hline 16 & $\mathrm{U}$ & & 16 & 0.000000 \\
\hline 17 & Lu & & 17 & 0.000000 \\
\hline
\end{tabular}

The alkali elements, $\mathrm{Na}, \mathrm{K}$ and $\mathrm{Cs}$, were not used in the remaining analysis because of their known potential for mobility. Lu, Ce, and $\mathrm{Tb}$ were not used because of their inability based on the step-wise discriminant analysis to distinguish between the Chumstick tuffs. Ba was not used because this study shows it to be mobile. Sample \# 3 from the tuff of Fairview Canyon has been altered to a bleached white color. This is probably the result of hydrothermal fluids from nearby intrusions. The concentration of Ba has dropped to $280 \mathrm{ppm}$ from 2,260 ppm and $3,100 \mathrm{ppm}$ in the two unaltered samples (see Table VI). Ba has also dropped from 3,000 ppm in sample \#48 of the tuff of Horse Lake Mountain number one to $800 \mathrm{ppm}$ in the 
altered sample\# 47 (see Table VIII). Cobalt and Cromium vary substantially between samples from individual tuff beds. Analysis of samples taken stratigraphically through tuffs Tcty 2 and Tcty 3 show $\mathrm{Cr}$ and Co to vary considerably with detrital content. Thus, $\mathrm{Cr}$ and $\mathrm{Co}$ were also omitted from the remaining analysis.

\section{DISCRIMINANT ANALYSIS}

Eight analyses from tuff beds of uncertain correlation were submitted to discriminant analysis (Appendix B) to be correlated with the recognized Chumstick tuff bed sequence. Samples from the tuffs of Horse Lake Mountain two and three (Tcth2 and Tcth3) both correlate with the tuff of Yaxon Canyon number three (Tcty3). The unaltered sample from the tuff Horse Lake Mountain one (Tcthl) correlates with the sixth tuff in Clark Canyon (Tctc6). Both of the samples from the tuff exposed in the east fork of Mission Creek (Tctem) were correlated with the tuff of Clark Canyon four (Tctc4). The unnamed tuff exposed along Eagle Creek Road (Tct?) correlates with the tuff of Clark Canyon number five (Tctc5), and the tuff exposed on the east side of the Eagle Creek anticline (Tct?) is correlated with Tctc5.

Horse Lake Mountain is a structurally complex area (Gresens, 1983). Thus, the projection of Tcthl to one 
of the Yaxon Canyon tuffs, the most likely stratigraphic equivalent, is difficult. Given the known tephrostratigraphy in the graben the correlation between Tcthl and Tctc6 is not possible without a radical reinterpretation of the structure in the basin and thus is discounted. Tctc6 is approximately 3,400 stratigraphic meters above the Yaxon Canyon tuffs. It is possible that Tcthl had not been previously recognized in the tephrostratigraphy of the Chumstick Formation. If Tcthl is a new tuff bed, it would be projected stratigraphically between Tcty 3 and Tctf. This is possible since the exposure between the two tuff beds is very poor. The other correlations made by discriminant analysis are favorable inlight of the stratigraphy and structure.

Figure 6 shows a scatter plot of the tuff samples based on the first two canonical discriminatory functions (see Appendix B). These two functions possess 83.48 of the discriminatory power present in the chemistry of the tuff beds. The plot seperates most of the Chumstick tuff beds. In the analysis which generated Figure 6 , Tcthl is predefined as a distinct tuff and not an unknown. Both samples of Tcthl plot seperately from the other groups. Tuff beds Tctyl and Tctml plot off scale to the left. Tcth 2 and Tcth 3 clearly plot with Tcty3, and the two Tctem samples plot with Tctc4. Individual samples used to define the tuff beds 
DISCRIMINANT ANALYSIS SCATTERPLOT

- indicates a group centrotd

CANONICAL DISCRIMINANT FUNCTION 1

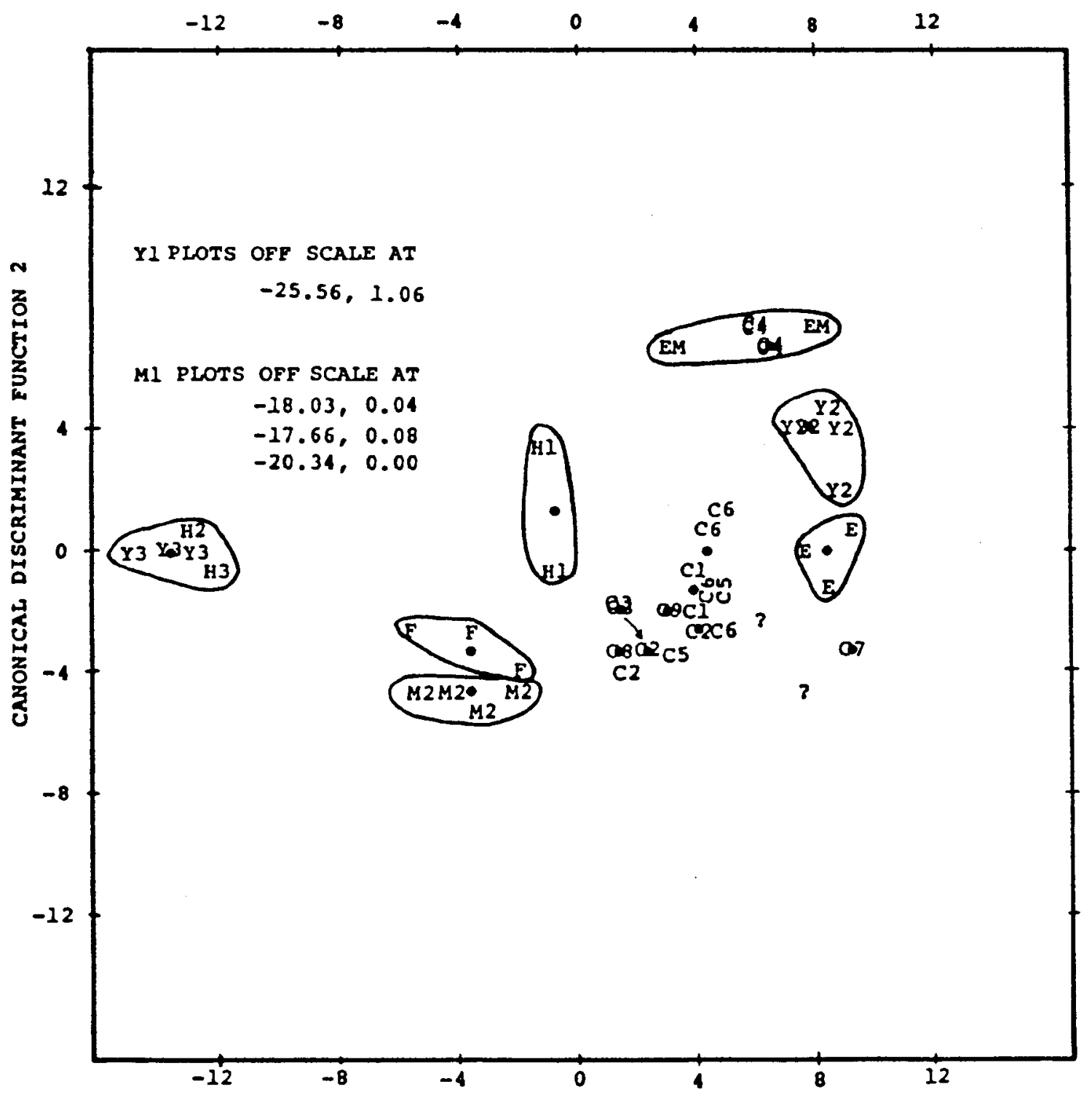

Figure 6. Discriminant analysis scatterplot 
were classified by the discriminant analysis. With two exceptions, all samples were correctly classified. The percent of grouped cases correctly classified for the Chumstick tuff beds is 95.28 . Sample \# 44 from Tctcl was incorrectly correlated with Tctc5, and sample \# 30 from Tctc6 was incorrectly correlated with Tctc9.

\section{CLUSTER ANALYSIS}

Figure 7 shows the dendrogram produced by cluster analysis (Appendix C). In the dendrogram, two tuff samples with similarity coefficients close to 1.0 , or most similar to each other, are tied together. The $x$-axis indicates similarity values. The similarity between two samples is obtained by projecting the point where they are tied to the $x$-axis. The similarity values of the two are then averaged and the two samples are tied with the sample which is most similar to this average. This process continues until all samples or groups have been tied together.

Two major groups are present in the dendrogram.

Group A consists of tuffs: Tctc4, Tctem, Tctm1, Tcty2, Tcty 3 , Tcth1, Tcth2, Tcth3, and possibly Tctc6. Tuffs Tcty 3 , Tcth2 and Tcth3 are probably the same unit. Tuff Tctc6 is present in both groups indicating the variability in its chemistry. Group $B$ is composed of tuffs: Tctm2, 


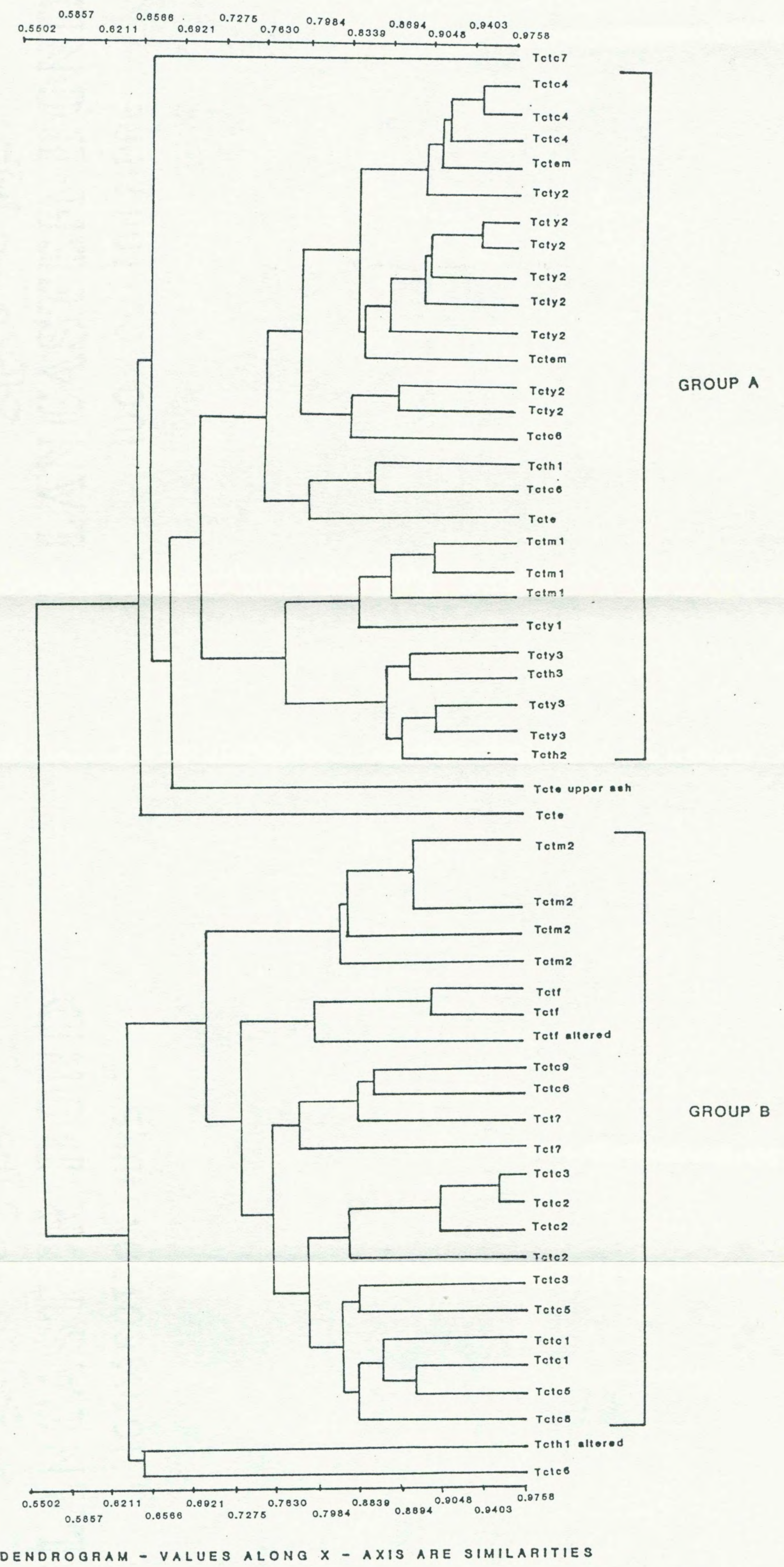

Figure 7. Cluster analysis dendrogram 
Tctf, Tctcl, Tctc2, Tctc3, Tctc5, Tctc6(?), Tctc8, and Tctc9. These two groups may represent tephra deposits from chemically different volcanic fields (Sarna-Wojcicki, $1979)$.

Because the Chumstick tuffs are physically traceable, it was known prior to the cluster analysis which samples should tie together. Since the samples were not biased, it is very encouraging to see the majority of samples tied to samples known to be from the same tephra bed.

Cluster analysis predicted the same correlations as discriminate analysis except for the two unnamed tuff exposures. The exceptions may be the result of the problems with the reproducibility in chemistry of Tctc6 with which the two are tied, and the fact that the unnamed tuff on the east side of the Eagle Creek anticline is quite detrital rich.

\section{GRAPHICAL ANALYSIS}

The ternary plot of $\mathrm{Hf}, \mathrm{Th}$ and $\mathrm{La} / 3$ (Figure 8 ) and the plot of Eu versus Hf (Figure 9) provide examples of less complex ways in which the Chumstick tuff beds can be individually separated based on their chemistry. The tuffs from group $A$ and group $B$ in the cluster analysis dendrogram (Figure 7) can be separated by the dashed line 


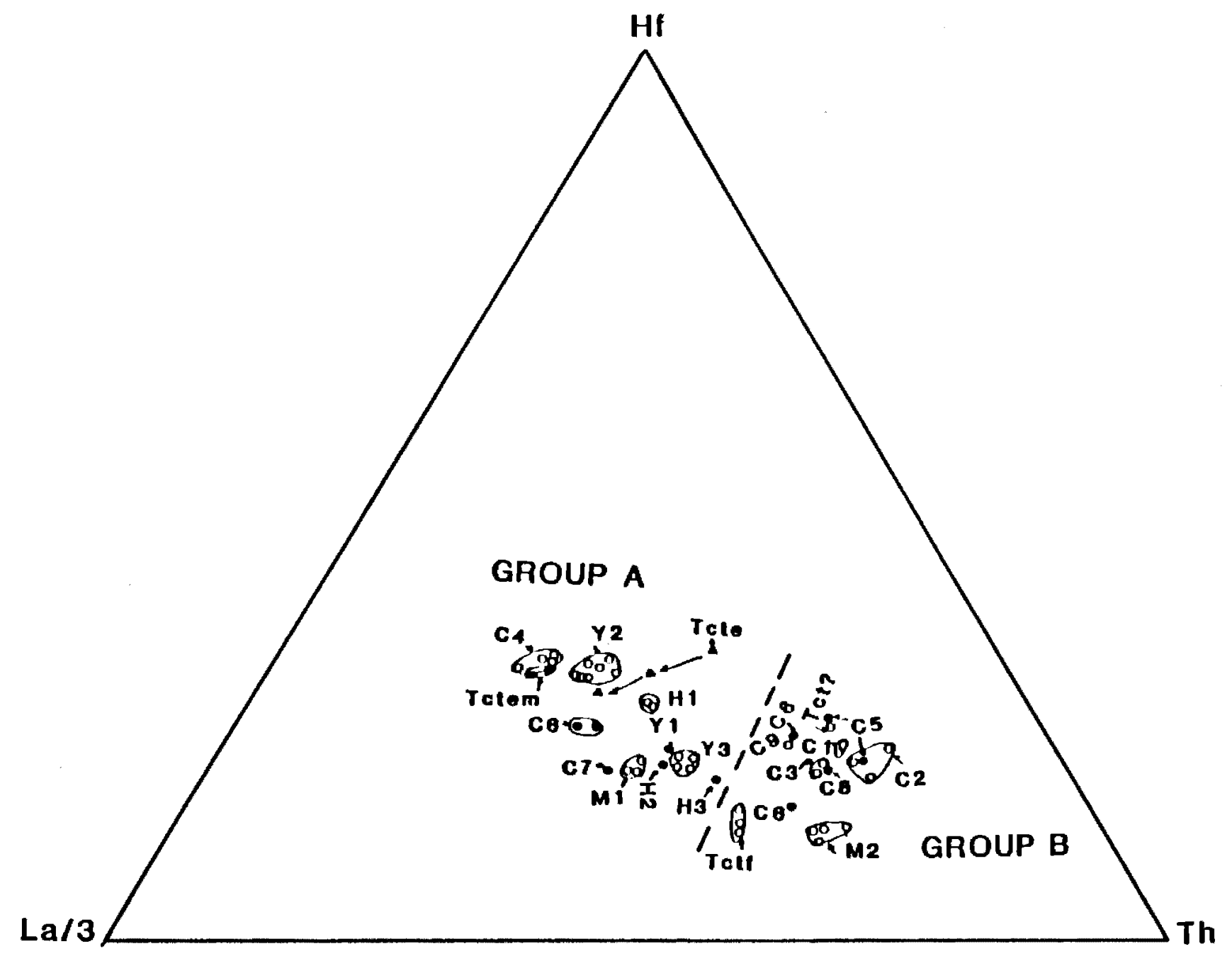

Figure 8. HE, Th, La/3 ternary plot 


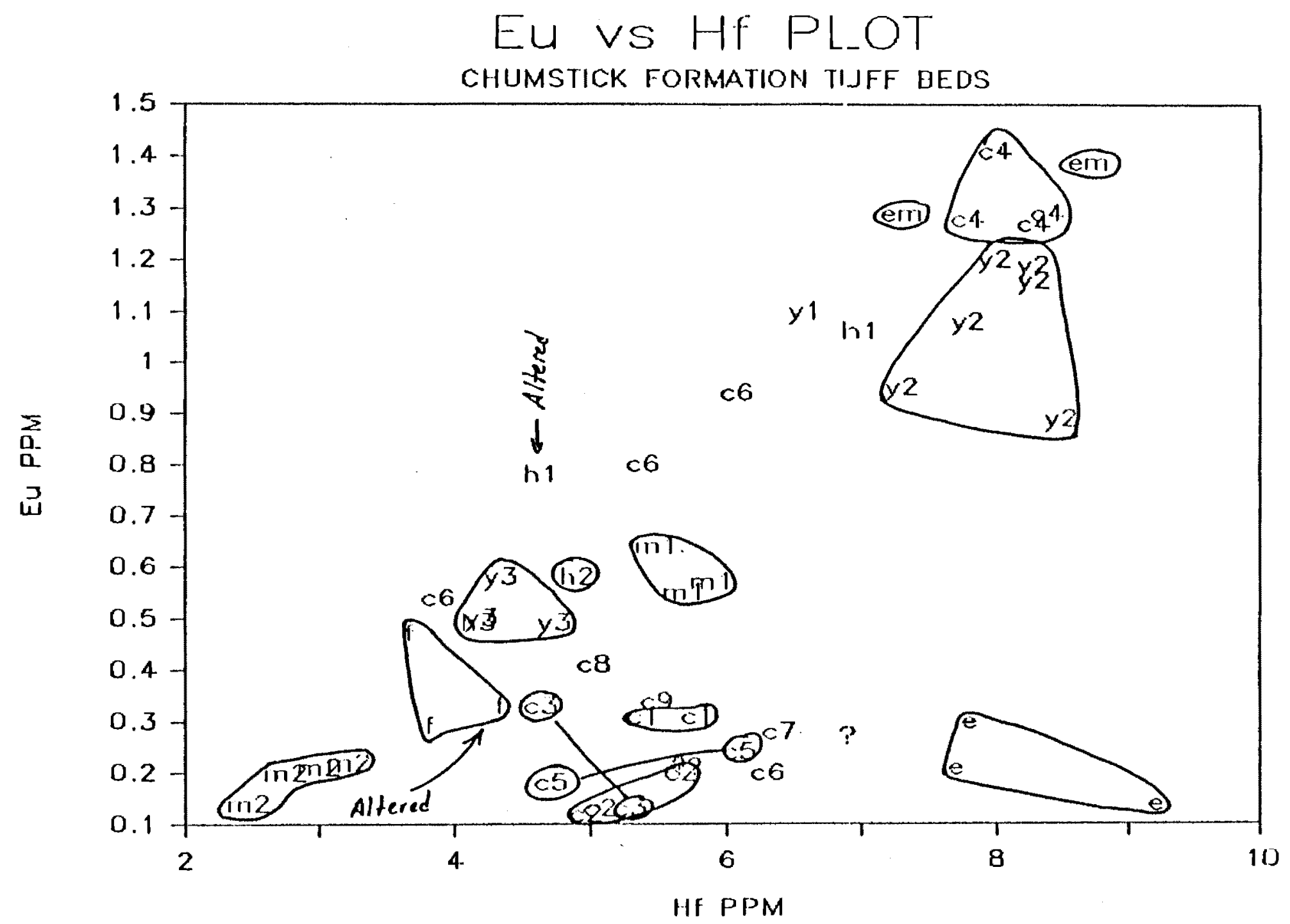

Figure 9. Eu versus Hf plot of the Chumstick tuff beds. 
in figure 8. The diagrams show the similarities and possible correlations between tuff beds Tctc4 and Tctem, between tuff beds Tcty 3, Tcth 2 and Tcth3, and between tuff beds Tctc 5 and Tct?.

Visual representations of the chemistry of the Chumstick tuff beds are obtained by normalizing the concentrations of elements present in the tuff by the concentration of elements present in a standard and plotting the ratios in a histogram. Individual samples can be compared by plotting the differences between histograms. Histograms and their differences were plotted for those chumstick tuff beds whose stratigraphic positions were uncertain and for those tuff beds with which they may correlate (Eigures $10,11,12$ ).

Histograms of the tuff of Yaxon Canyon three are very similar to the histograms of the tuff of Horse Lake Mountain two and three. Histograms from the tuff of East Mission Creek, the tuff of Eagle Creek and the tuff of Clark Canyon four exhibit the similarity between tuff beds Tctc4 and Tctem, and they futher show the dissimilarity of the trace element chemistries of Tcte and Tctem. Except for the positive ratio of $F e$ in the unnamed tuff exposed along Eagle Creek Road, the ratio pattern is similar to that of the Tuff of Clark Canyon five as previously projected by the discriminant analysis.

Ratios are calculated by using the concentrations 
Tuff of Yaxon Canyon * $3 \mathrm{Spl}$ \$5
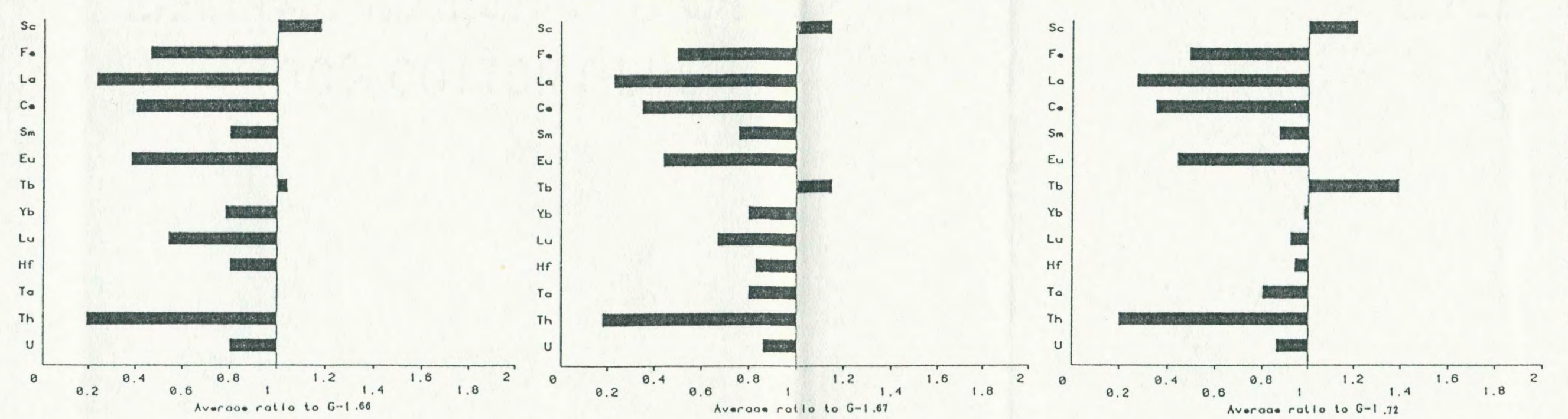

Tuff of Yaxon Canyon \# $3 \mathrm{Spl}$ \#5 Tuff of Yaxon Canyon \# $3 \mathrm{Spl}$ \#6

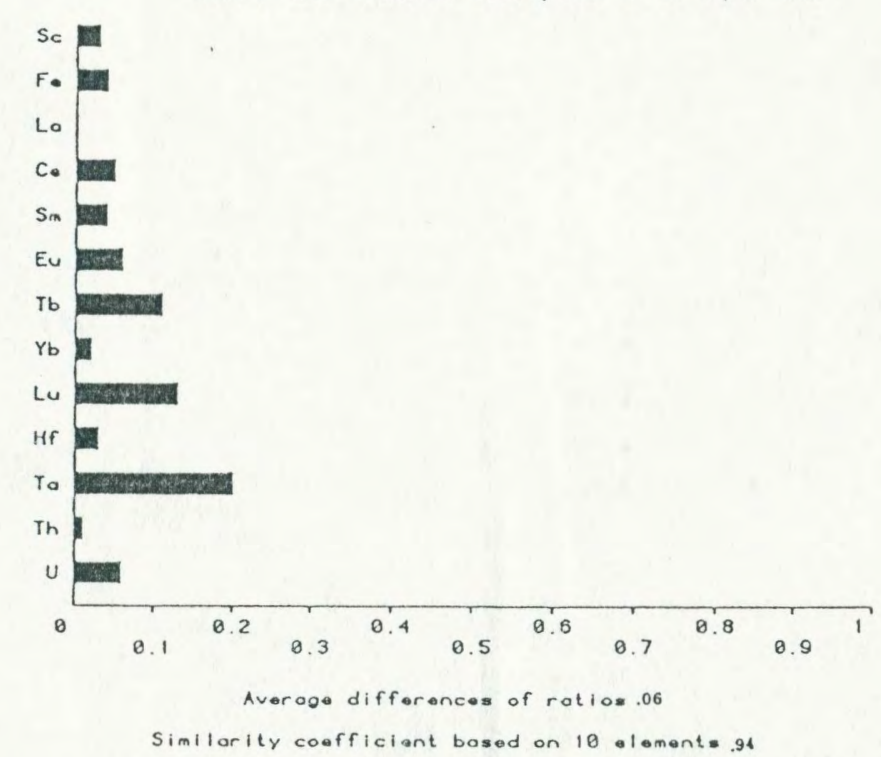

Tuff of Horse Lake Mountain \#2 Spl \#49 Tuff of Yaxon Canyon \# $3 \mathrm{Spl} \# 6$

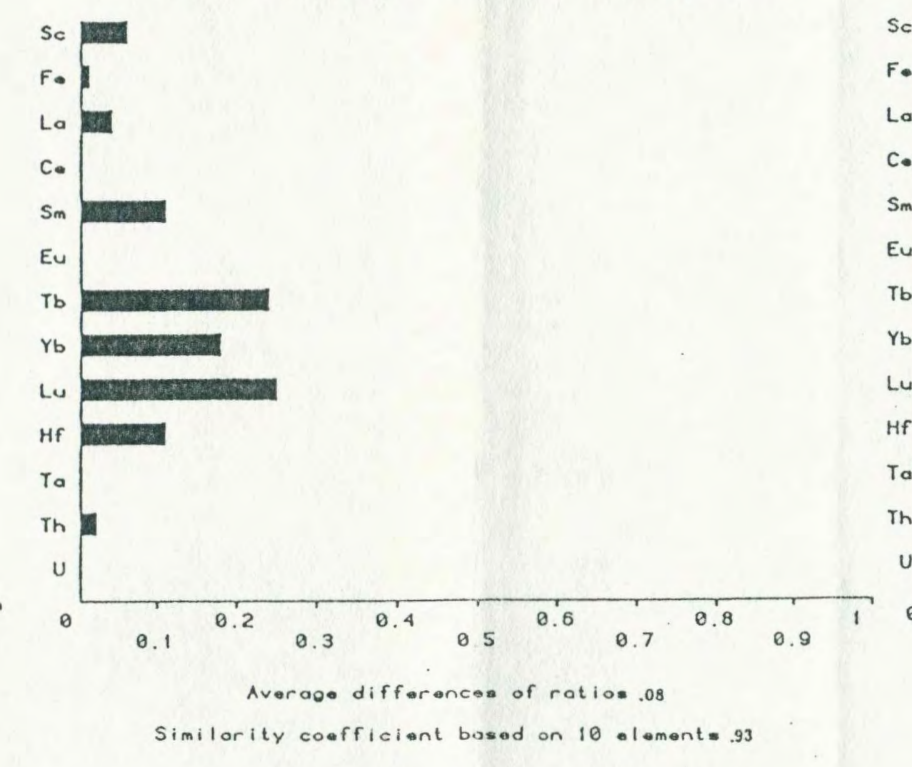

Tuff of Horse Lake Mountain \# $3 \mathrm{Spl} \# 50$ Tuff of Yaxon Canyon * $3 \mathrm{Spl} \# 6$

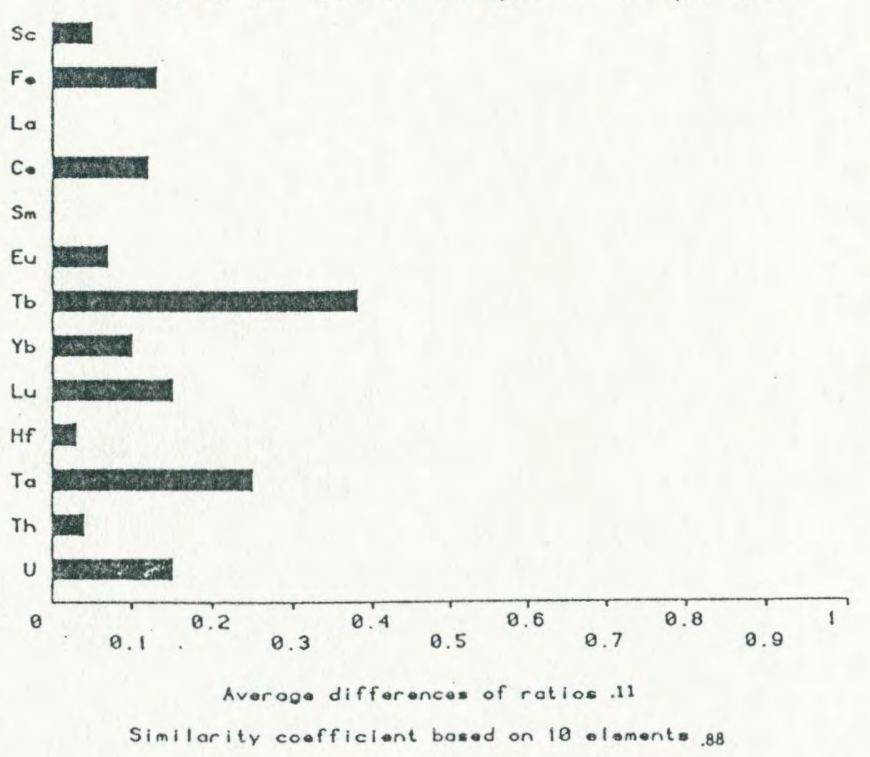

Tuff of Horse Lake Mountain \# $3 \mathrm{Spl} \# 50$

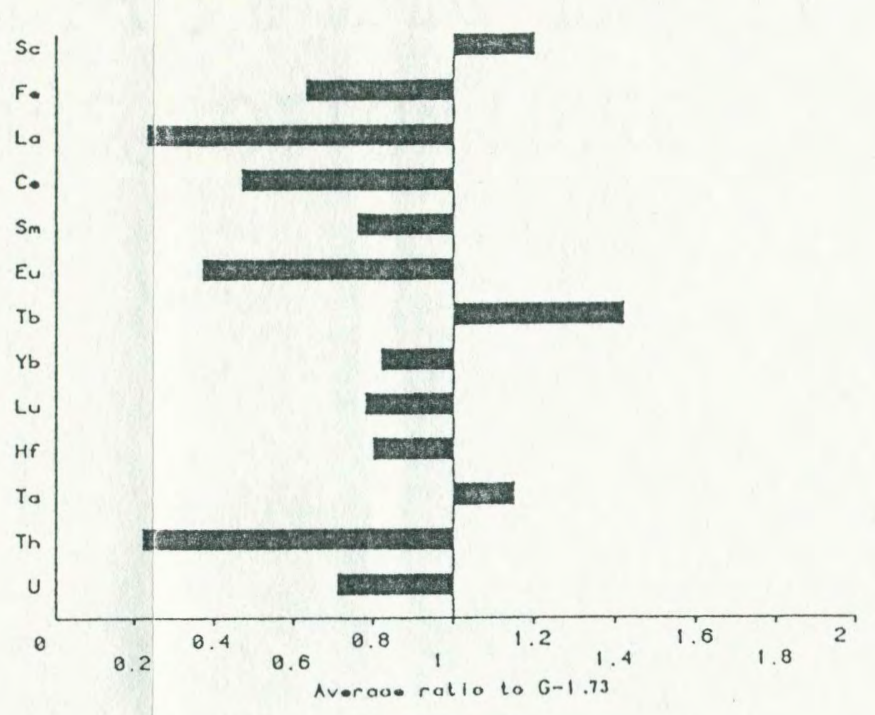

Tuff of Horse Lake Mountain \# 2 Spl \#49 Tuff of Horse Lake Mountain \# 3 Spl \#50

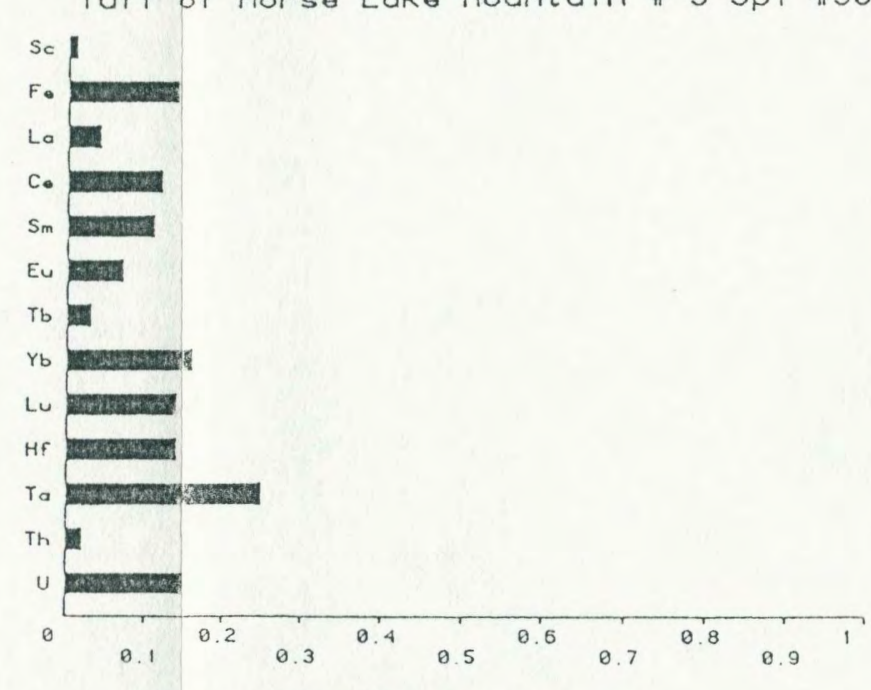

Average difforancos of ratios 10
Sim lority coofficient bosod on 10 elements

Figure 10. Elemental histograms for the tuff of Yaxon Canyon three,

the tuff of Horse Lake Mountain two and the tuff of Horse Lake Mountain

three. 

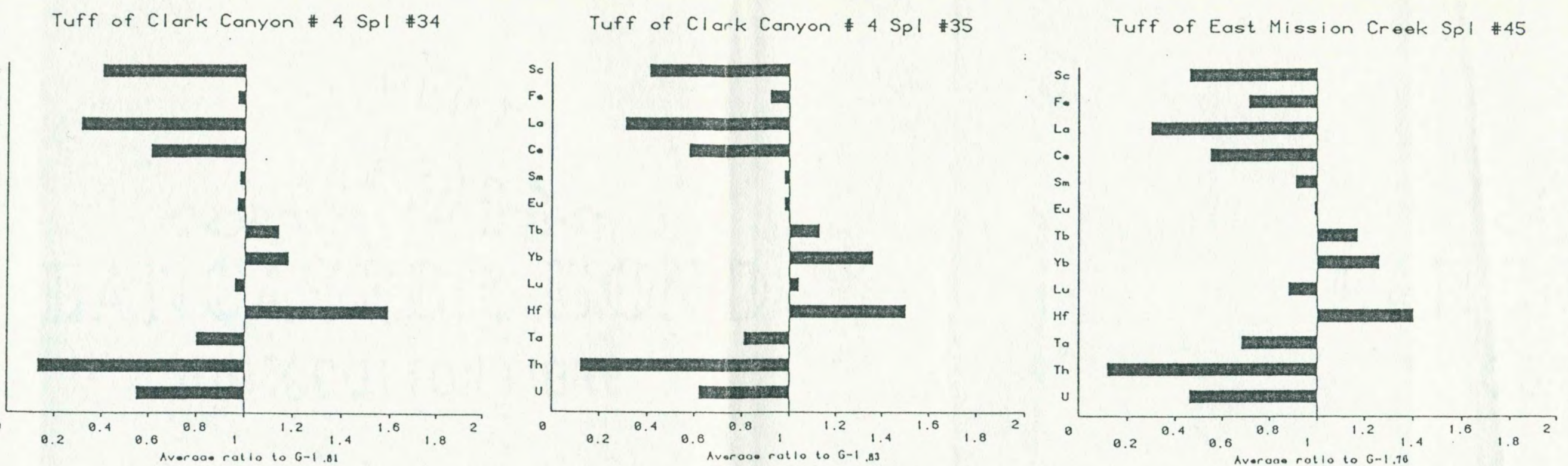

Tuff of Eagle Creek Spl \#22

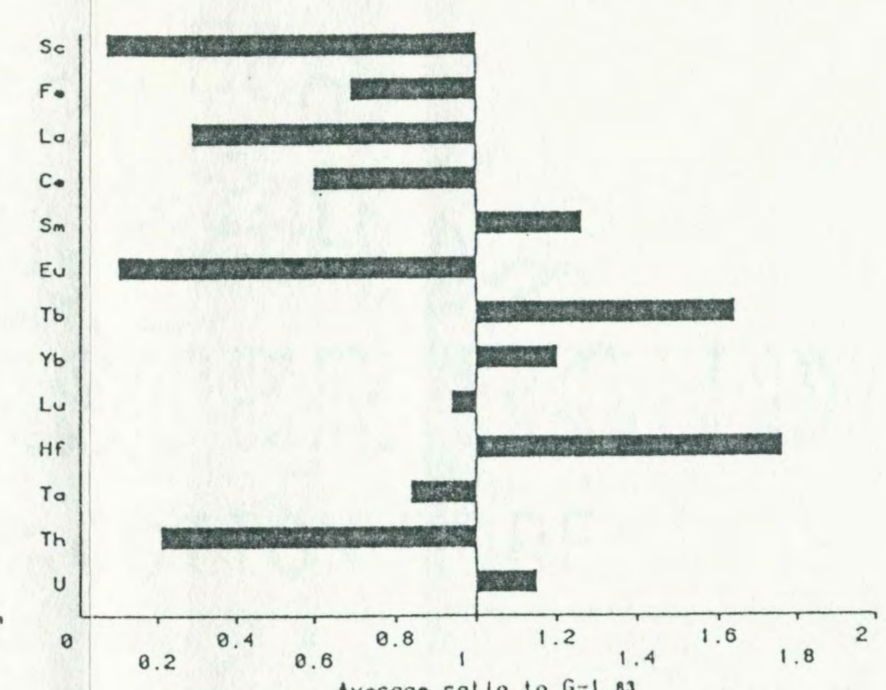

Tuff of Clark Canyon \# $4 \mathrm{Spl}$ \#34
Tuff of Clampared to Canyon \#4 Spl \#35

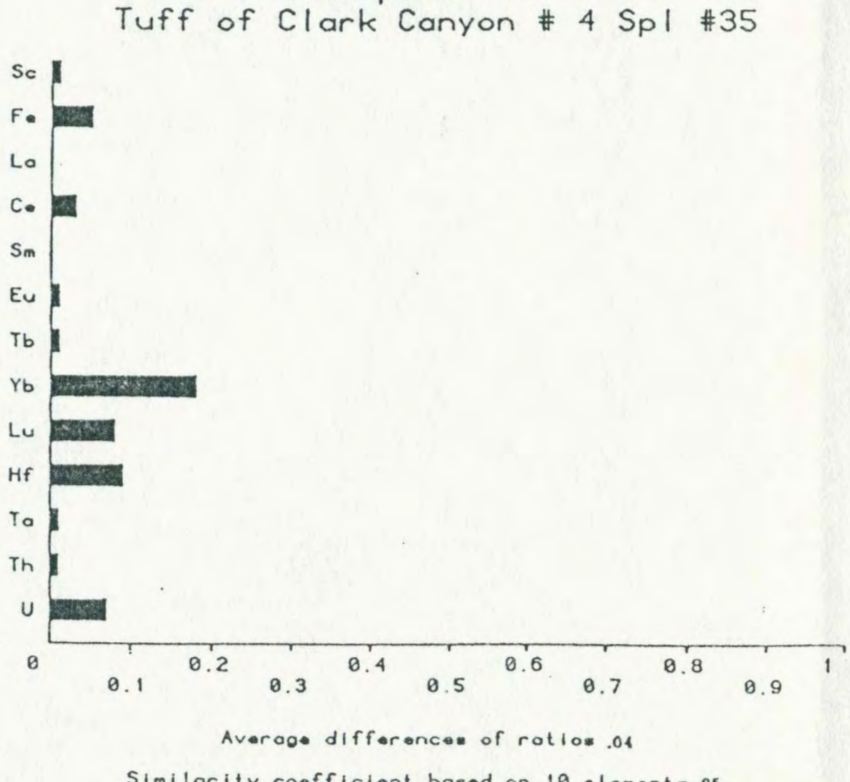

Tuff of Clark Canyon \#4 Spl \#34

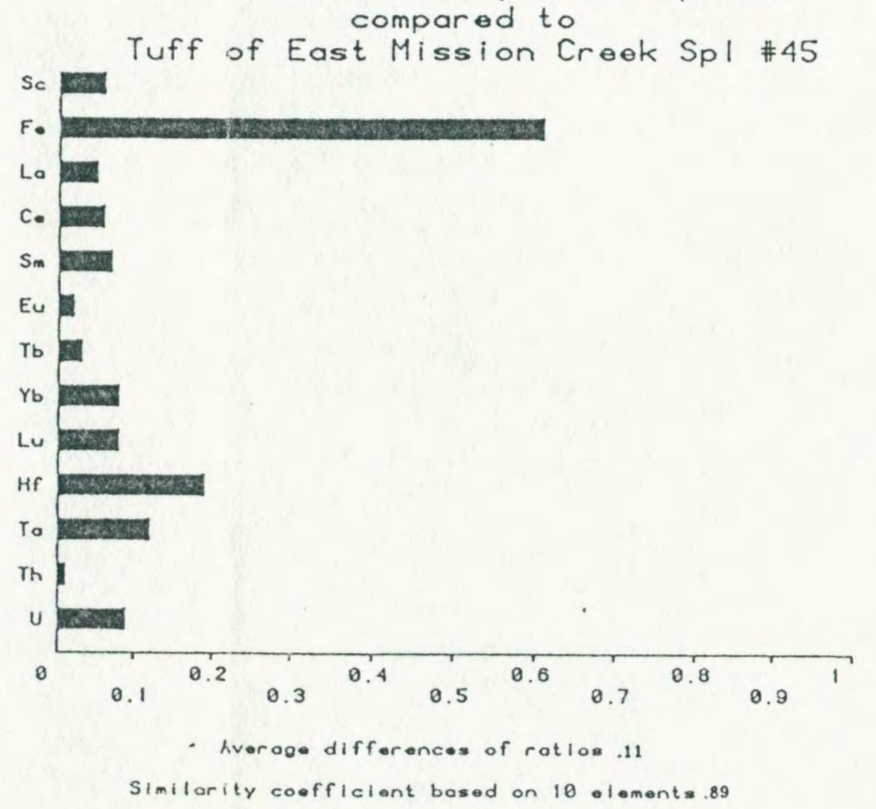

Tuff of Eagle Creek Spl \#22 Tuff of East Mission Creok Spl \#45

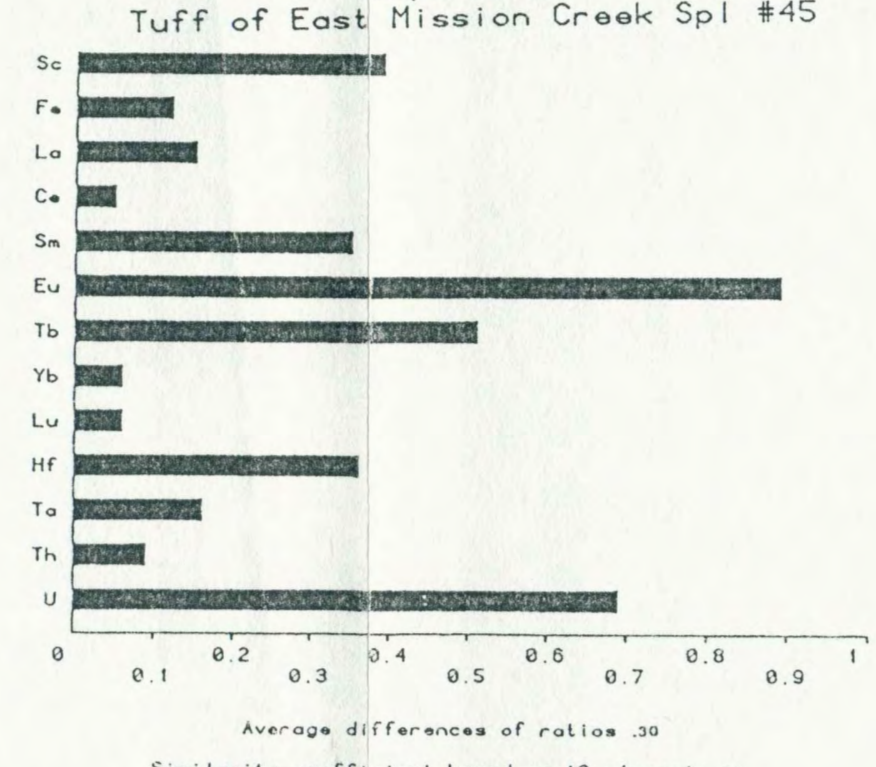

Figure 1l. Elemental histograms for the tuff of Clark Canyon four, the tuff of East Mission Creek and the tuff of Eagle Creek. 
Tuff of Clark Canyon *5 Spl \#32
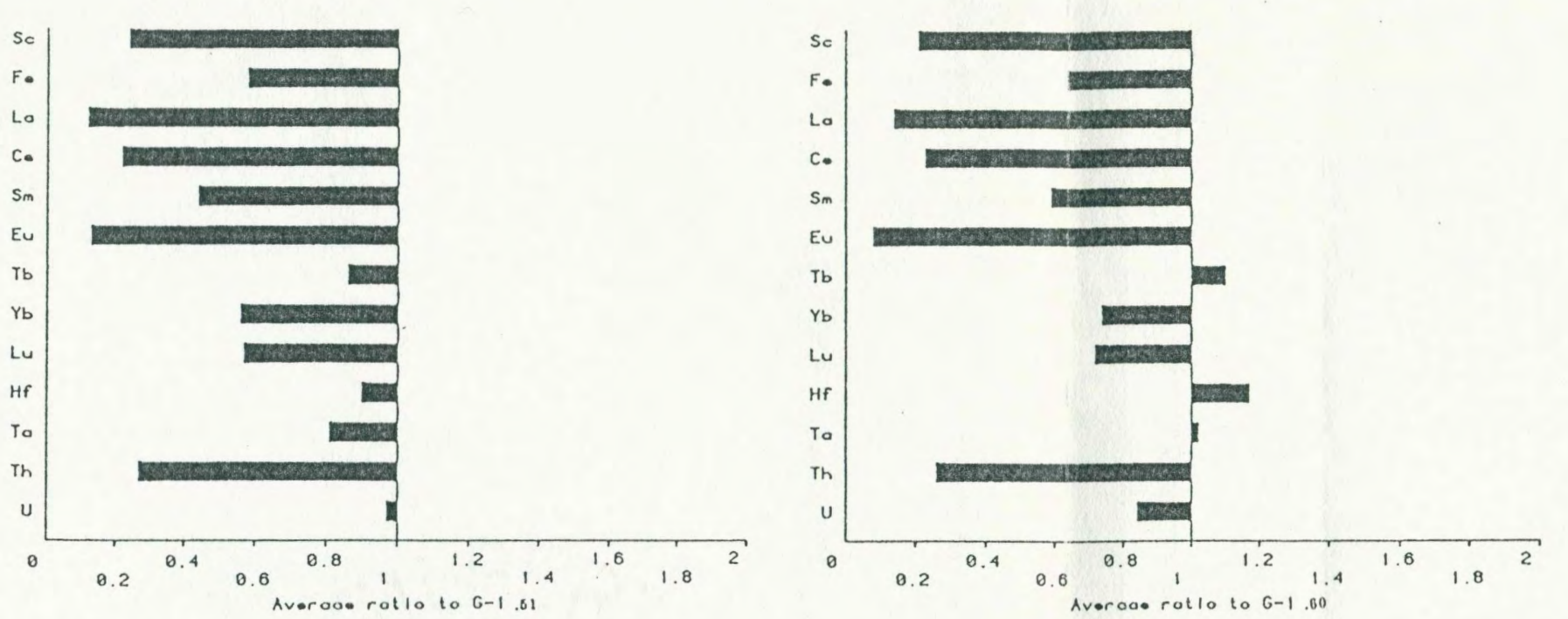

Tuff of Clark Canyon \# 5 Spl \#32 Tuff of Clark Canyon \# $5 \mathrm{Spl}$ \#33

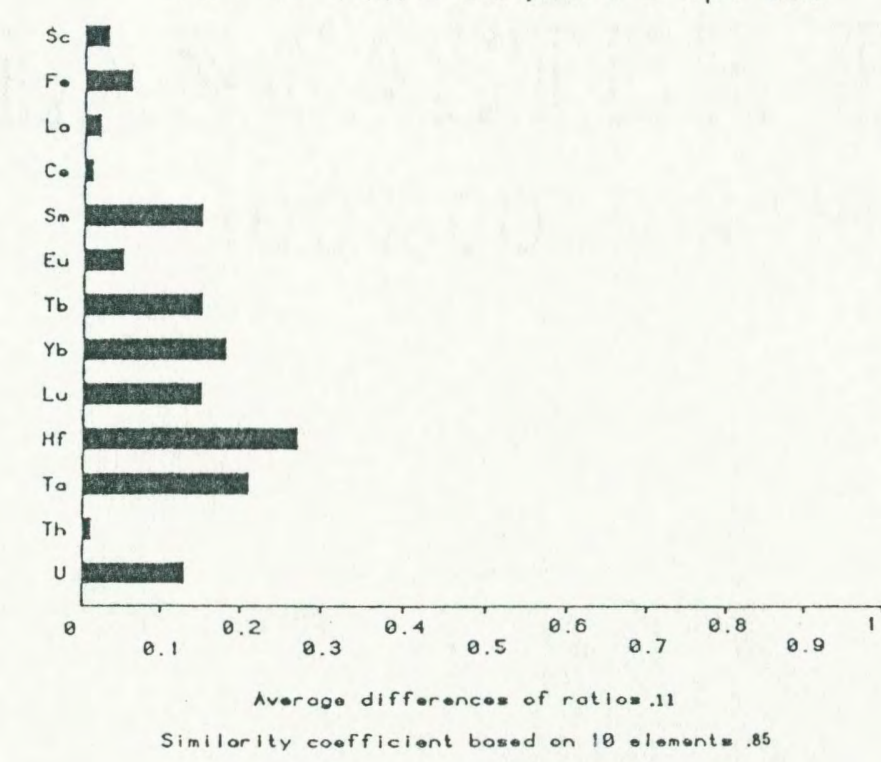

Tuff of Clark Canyon \#5 Spl \#32 compared to
Unnamed Tuff Spl \#5!

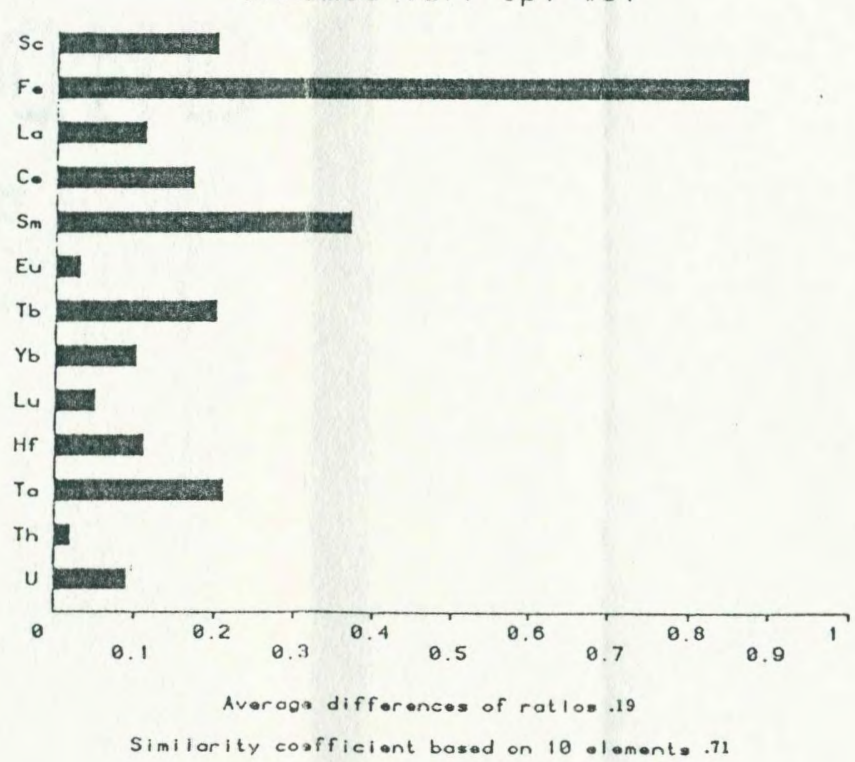

Unnamed Tuff exposed along Eagle Creek Road Spl \#5!

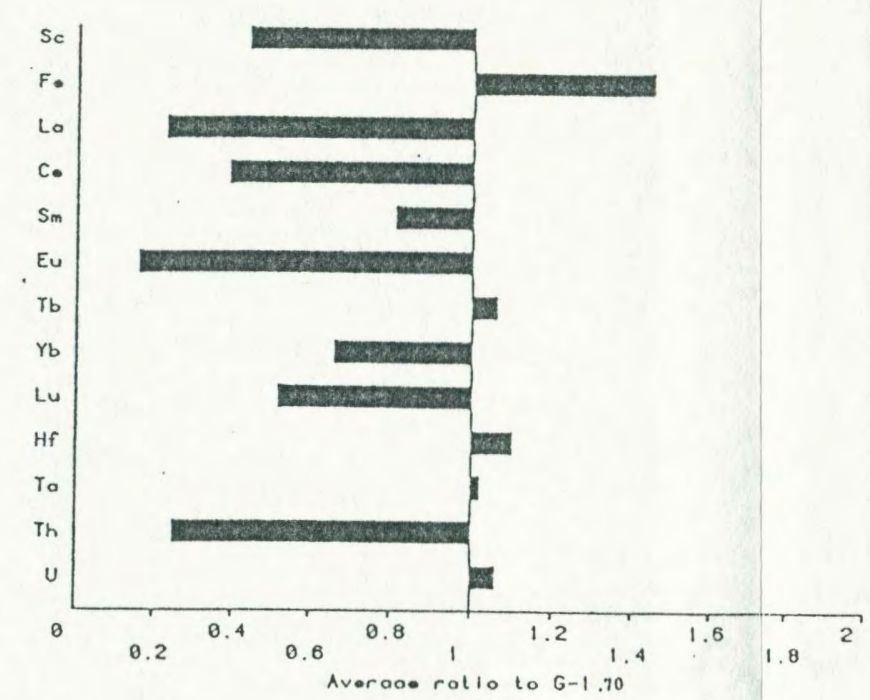

Tuff of Clark Canyon \# $5 \mathrm{Spl} \# 33$ compared to
Unnamed Tuff Spl \#5!

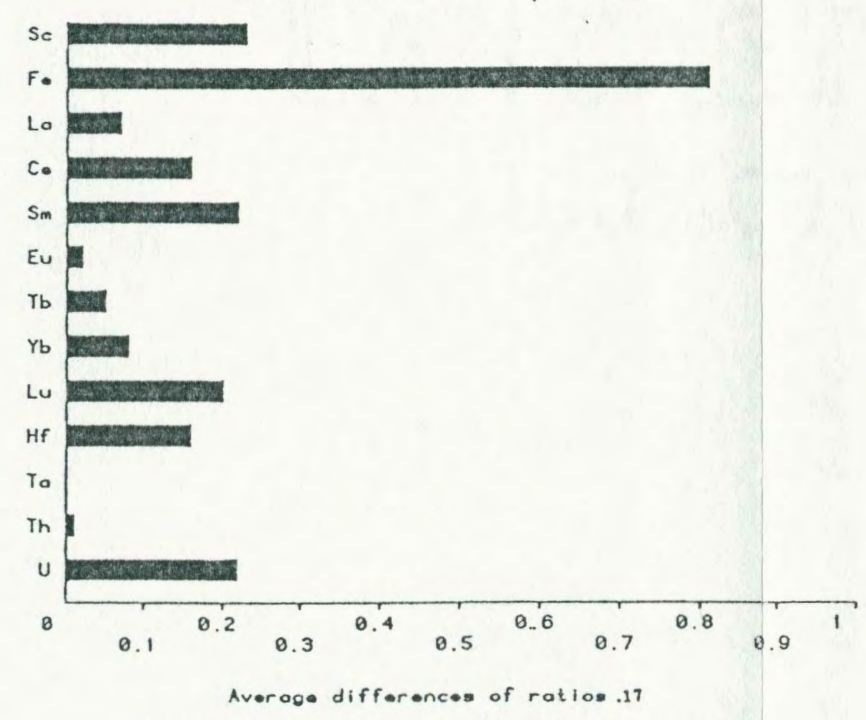

Similority coofficiont bosod on 10.1 omonts .77

Figure 12. Elemental histograms for the tuff of Clark Canyon five and the unnamed tuff exposed along Eagle Creek Road. 
of elements present in the U.S. Geological survey rock standard G-l. Elemental values are from Flanagan (1976) except for the values of Sc, Cs, Tb, Yb, Lu, and U. For which, the values of $7.0 \mathrm{ppm}, 4.0 \mathrm{ppm}, 1.0 \mathrm{ppm}, 5.0 \mathrm{ppm}$, $1.0 \mathrm{ppm}$ and $4.5 \mathrm{ppm}$ respectively were used. These values were arbitrarily chosen to maintain ratios between zero and two. This graphic method is adopted from sarna (1979) and used because one "can plot elements that vary in concentration by several orders of magnitude on a single scale."

Plots of chondrite-normalized rare-earth element concentrations for the tuff beds which have been suggested to be equivalent are shown in Figures 13,14 and 15 . The tuff of Yaxon.Canyon three (Tcty3) and the tuffs of Horse Lake Mountain two and three (Tcth2, Tcth3) which crop out 2 - $6 \mathrm{~km}$ to the SE have very similar REE patterns (Figure 13). Figure 14 shows very similar REE patterns for the tuff of Clark Canyon four (Tctc4) and the tuff exposed in the east fork of Mission Creek (Tctem). The slopes of REE plots from the tuff of Clark Canyon five (Tctc5) and the unnamed tuff exposed along the Eagle Creek Road (Tct?) (Figure 15) are quite similar. However, the concentration of REE is higher in Tct?. 


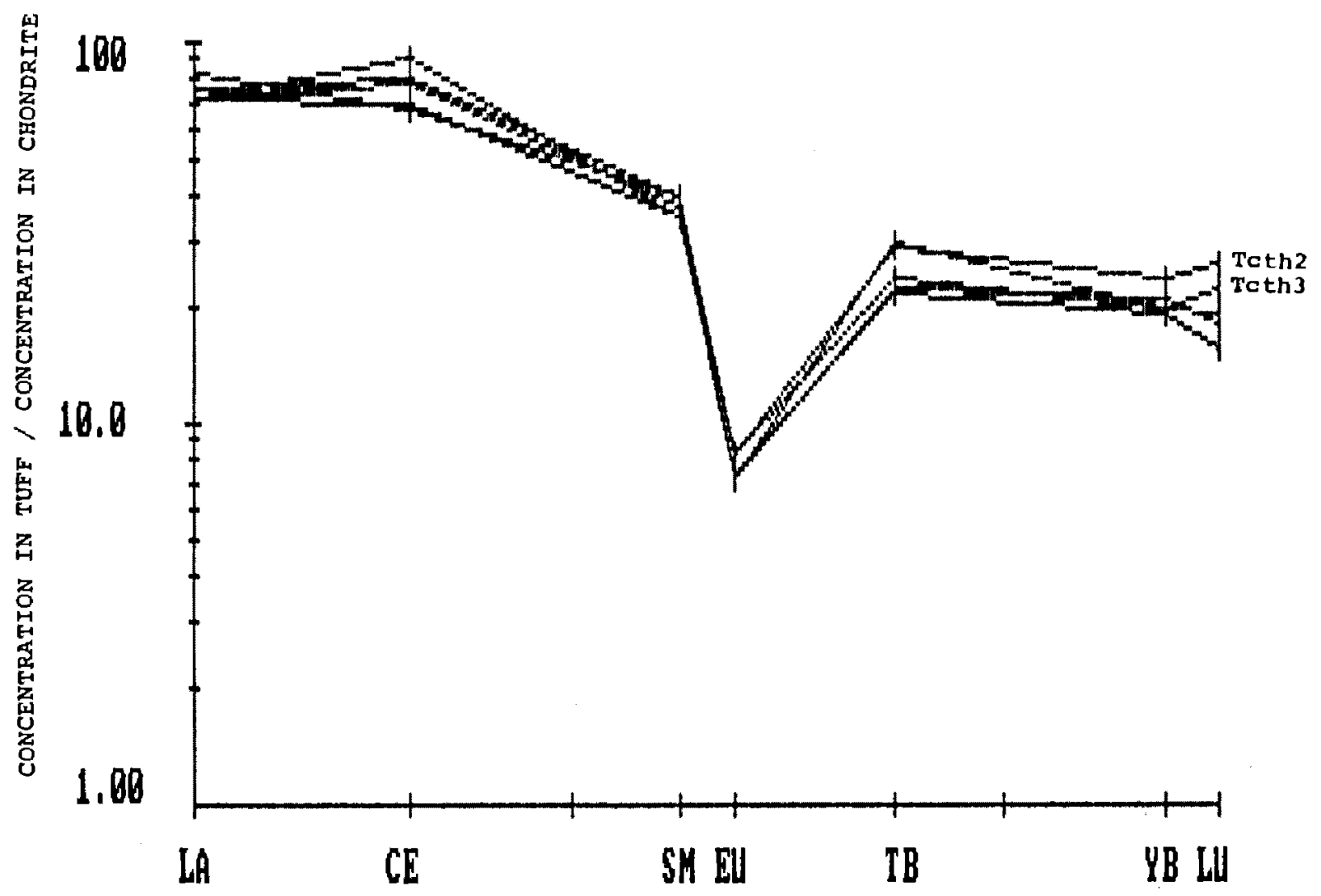

Figure 13. Chondrite-normalized plot of the rare-earth element concentrations in three analyses of Tcty 3 and one analysis of Tcth2 and Tcth 3. 


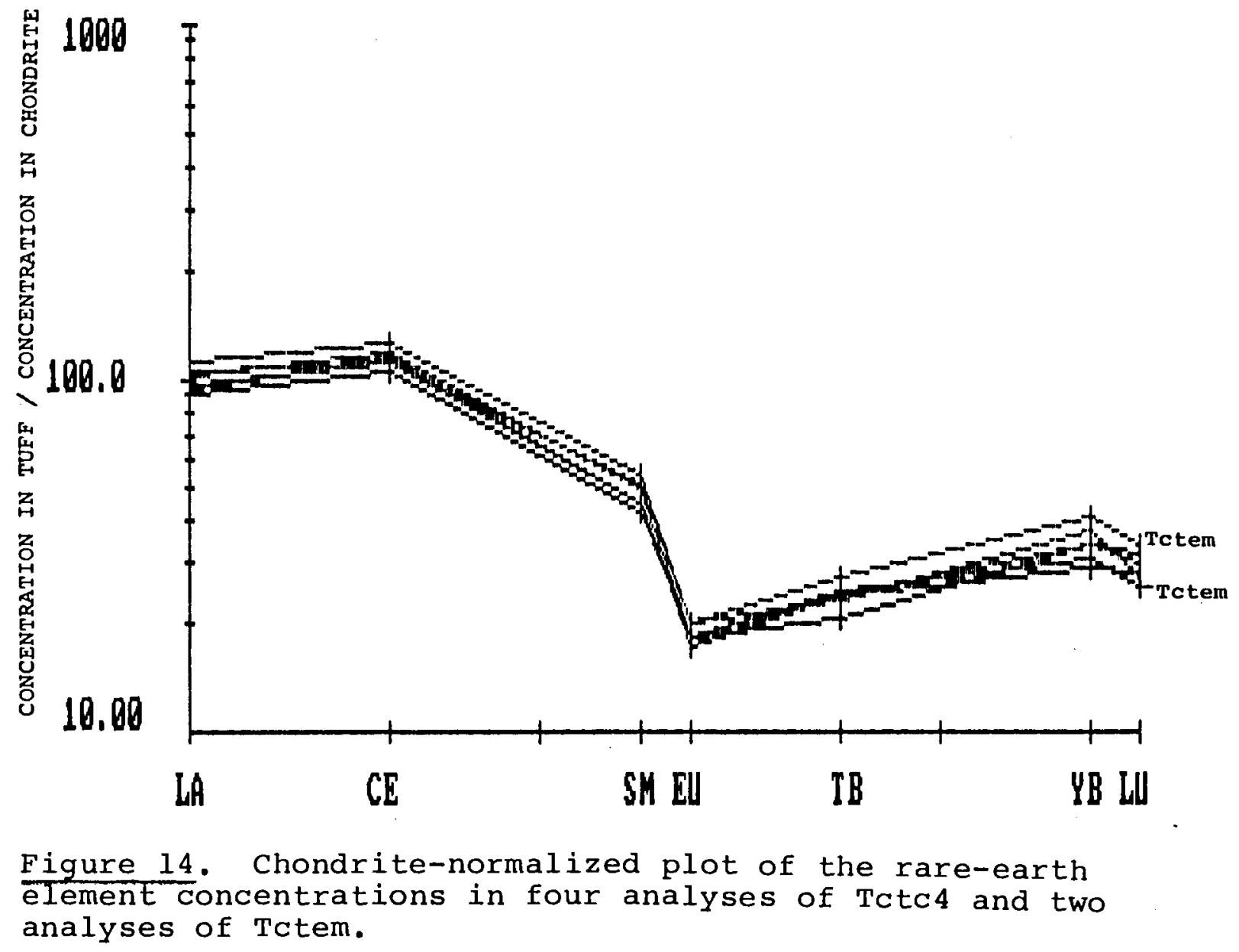




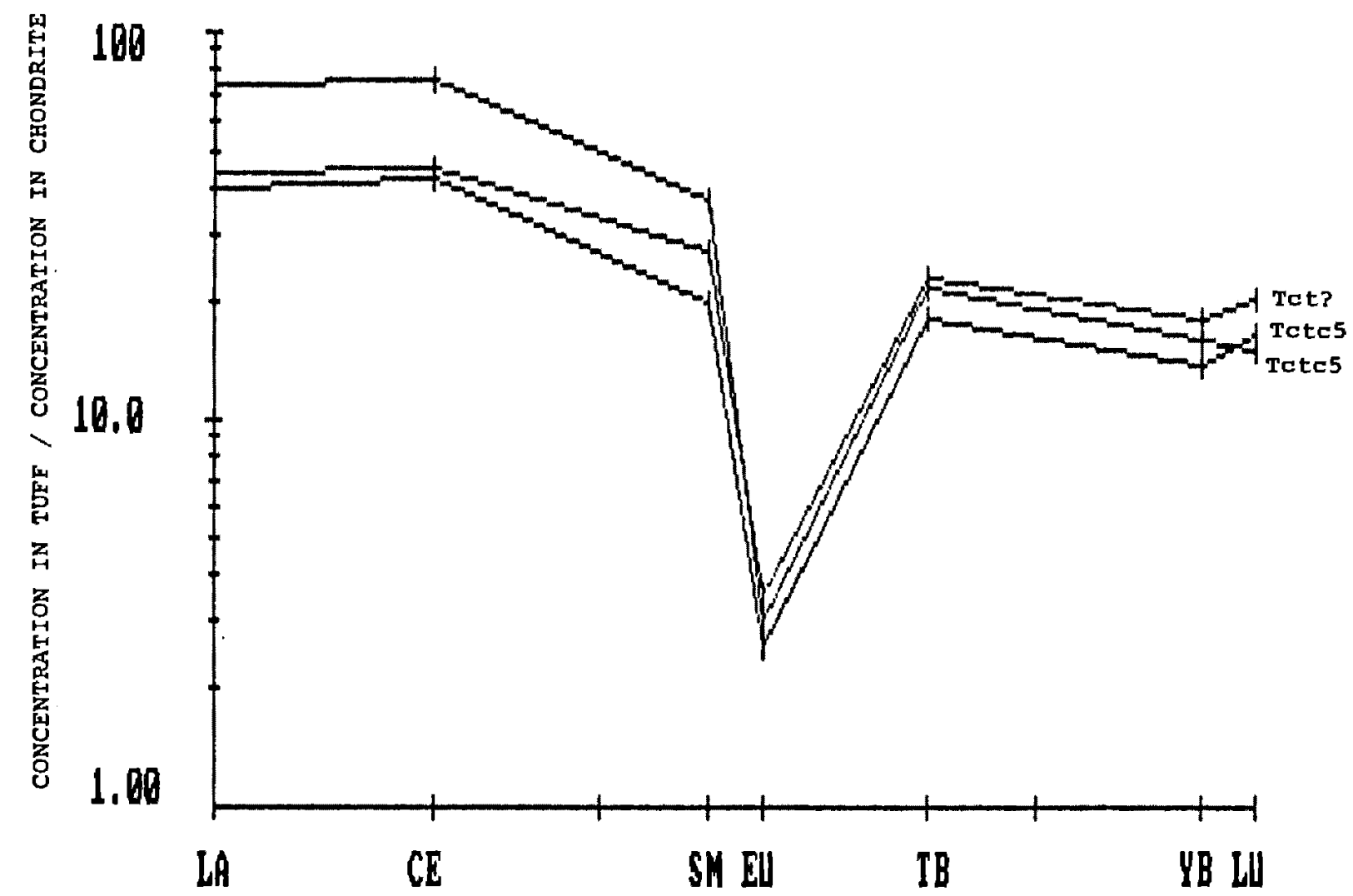

Figure 15. Chondrite-normalized plot of the rare-earth element concentrations in Tctc5 and Tct?. 
Ash-fall tephras commonly form wedge shape deposits which systematically thin along the dispersion axis (Fisher and Schmincke, 1984 p. 132). A common technique for projecting a vent location or direction to the vent for a given tephra bed is to produce an isopachous map of the deposit. This is done by recording deposit thickness and variation in clast size. The vent projection is then made on the a posteriori premise that the ash blanket thickens and coarsens toward the vent. The maximum thickness contour marks the source location or just down wind from it as it may be displaced from the wind (Fisher and Schmincke, $1984 \mathrm{p} .133)$. Unfortunately, the exposure provided by the homoclinal beds of the Chumstick Formation does not allow for the production of an isopachous map. Many of the tuff beds thin along strike to the south, leading one to assume a northern source. However, the sedimentary environment may have caused irregular thicknesses of the beds. Thickness irregularities may also result from differential compaction, contemporaneous errosion and local topographic irregularities (Fisher and Schmincke, $1984 \mathrm{p} .132$ ). Additionally, thinning to the south could reflect the systematic decrease in tephra thickness which takes place normal to the dispersion axis. Without a thickness control of the line of strike, it is not possible to confidently project a vent direc- 
tion. Based on recorded thickness values, the tuff exposures in the Chumstick Formation could have been produced from volcanic centers in any direction.

The Duncan Hill, Cooper Mountain and Railroad Creek plutons lie to the northeast of the Chiwaukum graben (Figure 16). The age dates for these plutons are in the same range as the Chumstick tuffs beds. This led Tabor and others (1982) to speculate that volcanos related to these plutons may have been sources for the Chumstick tuff beds.

The date by Tabor and others (1982) on a dacite dome west of Wenatchee at $43.2 \pm 0.4 \mathrm{~m} \cdot \mathrm{y} \cdot \mathrm{b} \cdot \mathrm{p}$. suggests the possibility of a more local source. This dome complex was implaced contemporaneous with Chumstick deposition and at a very shallow level possibly reaching the surface (Jacob Margolis, personal communication, 1985). These possible Eocene volcanic source areas are shown in Figure 16. Other possible Eocene volcanic sources may be covered beneath younger volcanic and sedimentary rocks.

Portions of tuff beds Tctc 2 and Tctc7 may have been deposited by lahars. At this time the dominant paleosedimentation directions were from the east to southwest and northwest (Evans, 1986). Lahars associated with volcanic eruptions to the east or northeast would have flowed on to the sedimentation plain. 
The tuff of Eagle Creek (Tcte) has abundant lithic clasts present. The nature of the clasts indicates that they are accidental rather than primary. The presence of fuchsite bearing gneiss clasts in the tuff and outcrops of a fuchsitic gneiss to the northwest (Paul Hammond, personal communication, 1984) leads to the speculation that the flow direction of the tuff of Eagle Creek may have been from the northwest. Further, the ash-flow thins and is reworked to the south.

The ash-flow tuff of clark Canyon four (Tctc4) shows a decrease in maximum pumice size from south to north (Plate 1). Some ash-flows exhibit a decrease in pumice size with distance from the vent (Sheridan, 1979). At its southern exposure in the center of sec. 10, T.23N., R.18E. (see Figure 35) the average of the ten largest pumice clasts is $2.6 \mathrm{~cm}$. Eight $\mathrm{km}$ to the north, in the SE $1 / 4$ of sec. 4, T. $24 \mathrm{~N},$, R. 18E., (see Figure 34 ) the average is $1.2 \mathrm{~cm}$, and $1.87 \mathrm{~cm}$ in sections 8 and 9 in Clark Canyon to the north. If Tctc4 and the tuff exposed in East Mission Creek are the same tuff as previously suggested, a southern source for Tctc4 is implied by the presence of pumice clasts up to $14 \mathrm{~cm}$ at exposure of Tctem on the east side of the syncline and a thickening of Tctc4 from $3 \mathrm{~m}$ at its Clark Canyon exposure to $6 \mathrm{~m}$ at exposure in the East Fork of Mission Creek.

The source volcanics for the Chumstick tuff beds 
are not known. However, decreases in bed thickness and sizes of pumice clasts with distance, and the association of mudflows with other tuff beds suggests that sources lie in both northern and southern directions. 
POSSIBLE EOCENE SOURCE VOLCANICS FOR TIIE CIIUMSTICK FORMATION

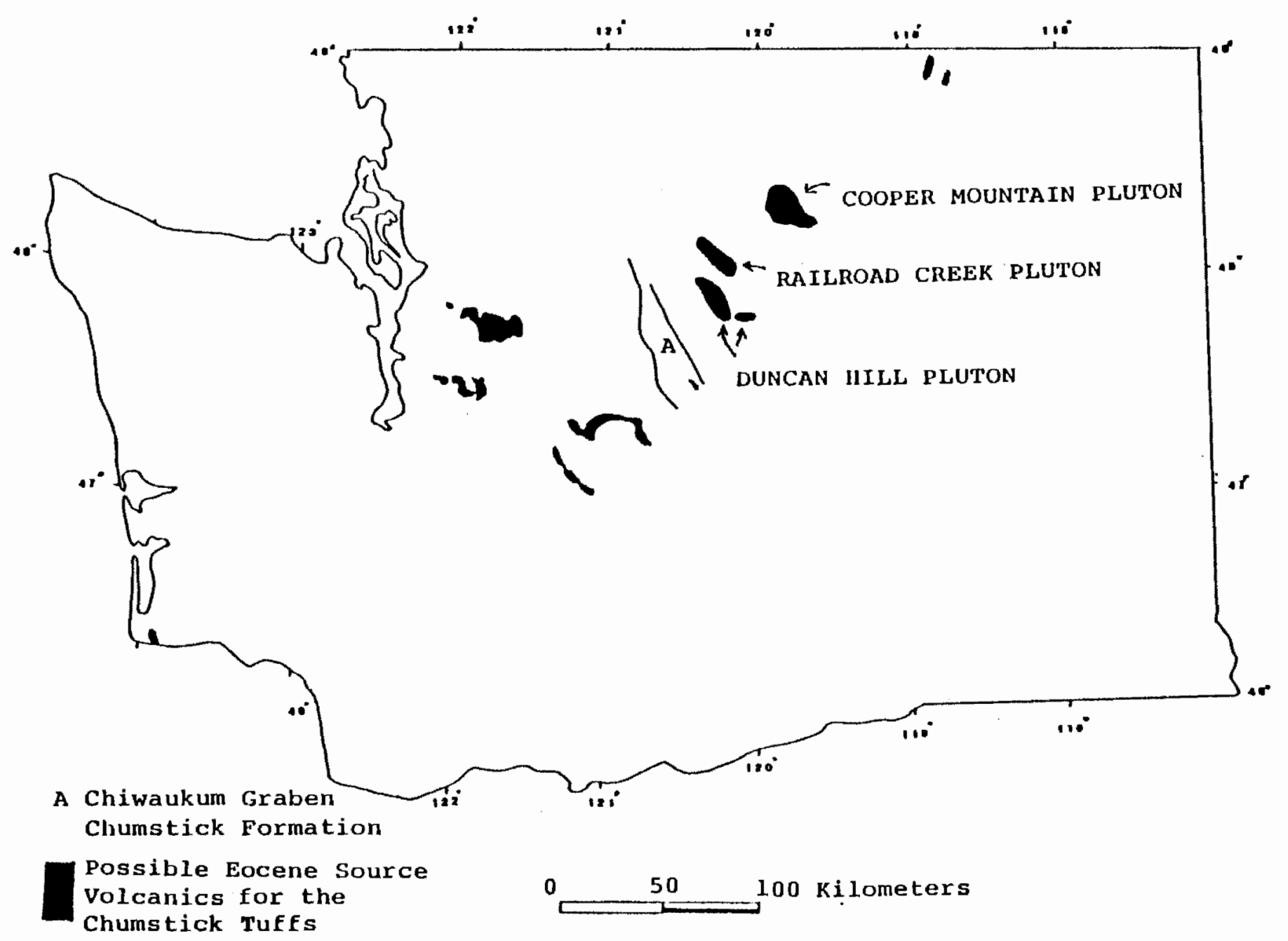

Figure 16. Possible Eocene source volcanics for the Chumstick tuff beds. 


\section{DISCUSSION}

The development of the Chumstick Formation tephrostratigraphy was aided by the fact that the tuff beds were diagenetically altered to resistant beds of chert, composed of quartz, clinoptilolite, or heulandite and smectite. The fact that these units are so continuous and mapable made them excellent field marker horizons. Recognizing the stratigraphic potential of these units, previous workers mapped them. What developed is a sequence of tuff beds which provide a workable field stratigraphy within a previously homogeneous thick sequence of continental sediment and further provided an excellent opportunity for this study.

The chemistry of the majority of the Chumstick tuff beds is reproducible along bedding, and graphical analysis shows that most of the units can be separated based on this chemistry. No repetition of tuff beds is seen in the formation. This confirms the earlier conclusion of Gresens (1983, p. 55) that the Chumstick Formation is indeed a very thick sedimentary sequence.

Scattered exposures of tuffs of uncertain stratigraphic position within the Chumstick Formation were compared to the characterized Chumstick tephrostratigraphy Three of these are the Horse Lake Mountain tuffs, Tcthl, Tcth 2 , and Tcth3. They were mapped by Gresens (1983) and are exposed around the structurally complex Horse 
Lake Mountain intrusive complex. Cluster analysis, discriminant analysis and graphical methods argue that Tcth 2 and Tcth 3 are the same unit and that they correlate with the third tuff exposed in Yaxon Canyon (Tcty3) five kilometers to the northwest. The lithologies of the three beds are similar, and they are exposed along strike. Petrography of the three exposures show they all contain apatite. A correlation between these three tuff beds seems reasonable in light of the favorable stratigraphic positions of the units and the chemical, petrographic and lithologic similarities.

The tuff of Horse Lake Mountain one (Tcthl) is chemically distinct from all the other Chumstick tuff beds. It is probably a previously unrecognized tuff bed in the Chumstick Formation projecting between the tuff of Fairview Canyon (Tctf) and the tuff of Yaxon Canyon three (Tcty 3$)$. The correlation by discriminant analysis of Tcthl with the tuff of Clark Canyon six (Tctc6), as previously stated, would require a radical structural reinterpretation of the Chiwaukum graben as the two units are separated by approximately 3,400 stratigraphic meters (Figure 17). The Hf, Th, La/3 ternary plot, the discriminate analysis scatter plot and the $\mathrm{K}$ versus Eu plot (Figures 8,6 and 20) distinctly separate the two units. The addition of a new tuff bed to the Chumstick Formation tephrostratigraphy brings to 19 the total of recognized 
TEPHROSTRATIGRAPHY.

OF THE CHUMSTICK FORMATION

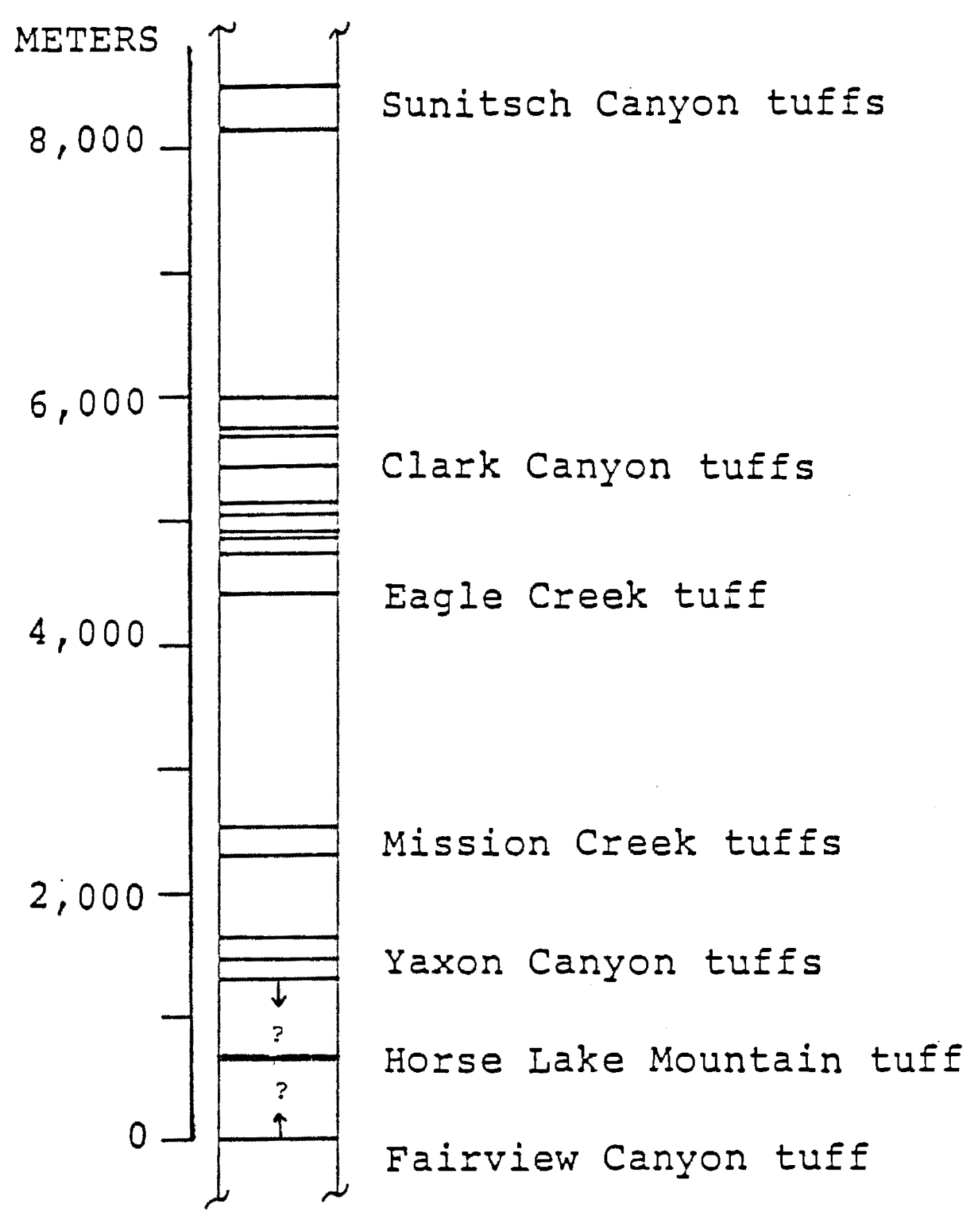

SOURCES: Evans 1985, Gresens 1983

Figure 17. Tephrostratigraphy of the Chumstick Formation. 
tuffaceous horizons in the formation.

Discriminant analysis suggests a correlation between the tuff of Clark Canyon five (Tctc5) and an unnamed tuff exposed along Eagle Creek Road. The lithogies and thicknesses of the two tuffs are similar, and they are both in the same approximate stratigraphic position. Ignoring the major Fe concentration difference between Tctc5 and Tct? the histograms (Figure 12) show similar patterns. In the ternary diagram, (Figure 8 ) the two units plot together. REE patterns of the two tuff beds (Figure 15) have the same slopes except Tct? has a higher concentration of the rare earth elements. This difference is potentially accounted for by dilution effects which can occur in bulk samples (Beeson, 1985, personal communication). The two samples from Tctc5 were not tied together in the cluster analysis dendrogram and plot apart in the ternary diagram (Figures 7 and 8 ). This indicates considerable variation in the chemistry between the two samples as does their average ratios to G-1 (Figure 12). Given this range of chemical variation, the similar lithologies, and stratigraphic positions, it is possible that Tct? and Tctc5 are the same tuff bed.

All three methods of analysis of the chemical data suggest a correlation between the tuff bed exposed in the upper East Fork of Mission Creek (Tctem), mapped by Tabor and others (1982), and the tuff of Clark Canyon 
four (Tctc4) $19 \mathrm{~km}$ to the northwest. This is in contrast to the correlation by Tabor and others (1982), of Tctem with the tuff of Eagle Creek (Tcte) on the basis of lithology.

All three of these tuff beds Tctem, Tctc4 and Tcte are ash-flow tuffs, but only Tcte and Tctem are easily identifiable as such in the field. Considerable lateral and vertical variations in lithology, chemistry and phenocrysts may exist within a single ash-flow sheet. This is in response to chemically zoned magma chambers and mechanical sorting which can take place in different flow and depositional regimes and topographic influences (Hildreth, 1985). Because of these factors, discrimination and correlation of ash-flow tuffs is more complicated than working with air-fall tuffs.

The methodolgy employed by this study was not designed to deal with the potential variations which exist in ash-flow tuffs. Fractionation and contamination problems but not compositional zonation can be dealt with by preferential analysis of pumice blocks or fiamme (Hildreth, 1985). It was not practical to sample pumice from these three units. As a result, much less desirable bulk samples were used to characterize these units.

Even with these potential problems, the chemistry of Tctc4, from four samples taken over a $21 \mathrm{~km}$ distance, was one of the most reproducible of the chumstick tuff 
beds. The chemistry of Tctc4 and Tctem, as shown by the REE and histogram patterns (Figures 11 and 14), are quite similar. The subtle variations which exist are explainable with the model of a zoned magma chamber or the problems of the sampling methodology. The lithologies of the two units are similar. They are both dense and glassy. Both units contain green hornblende, sanidine and zircon. Tctem is thicker; it has larger and more abundant pumice clasts. Its thickness and larger pumice size may indicate Tctem was deposited closer to the vent. If this correlation is correct, this is fair evidence for a source vent south of the Chiwaukum graben. The tuff of Eagle Creek is more crystal and lithic rich than the other two tuffs. As such, the use of bulk samples to chemically characterize this unit is not the most desirable. As expected, there is considerable variability in the three chemical analyses from this tuff bed. The spacing of the plots of these three samples in the ternary plot (Figure 8) and the low similarity of the three samples shown in the cluster analysis dendrogram (Figure 7) illustrates this point. However, the Eu versus Hf plot and the scatter plot (Figures 9 and 6) do group the three samples of Tcte together and seperate from the plots of the other tuff samples. Because of the probable zoning of the magma chamber which produced Tcte, the upper portion of the unit, which is very glassy and interpreted 
to be the air-fall constituent of the eruption, would possibly only reflect a portion of the range in chemistry of the tuff. Perhaps it is possible to account for the differences in lithology and chemistry between Tctem and Tcte by a zoned magma chamber. However, given the additional chemistry which Tabor and others (1982) did not have, the correlation of Tctem and Tctc4 is much more plausable.

Two major groups are present in the cluster analysis dendrogram (Figure 7) labeled Group A and Group B. These two groups may represent tephra deposits from chemically different volcanic fields. Field evidence in Sarna's (1979) study, of late Cenozoic tuffs in California, indicated that the tuff beds in his study were from two geographically separate volcanic fields. The chemistry of the tephras from a single volcanic province were similar to each other but different from the tephras of the other volcanic province.

Sarna-Wojcicki (1979) provided guidelines for using similarities to project membership of a tuff to a volcanic field or to correlate one tuff to another. Sarna-Wojcicki points out that the range of coefficients given by him only applies to the units studied and elements used. Thus, his numbers are only guidelines for use with the Chumstick tuffs. However, the similarity values generated for the Chumstick tuffs known to be from the same tuff 
bed are much lower than the values in Sarna-Wojcicki (1979). This is likely the result of bulk analysis of the Chumstick tuff samples resulting in larger variations. Consequently, the level of reproducibility of tuff chemistry is lower than Sarna's.

The two groups in the dendrogram (Figure 7) are tied at a similarity value of 0.5660 . Tuff Tctc7 is either unique in its chemistry or the fine detrital admixture seen in thin section may be sufficient to affect the chemistry. It is tied to group $A$ at a similarity of 0.6639 .

The ash-flow genesis of the tuff of Eagle Creek makes its chemistry suspect. However, the sample from the ash cloud constituent of the deposit should have a more reliable chemistry. It is quite different in chemistry from group A. It ties to group A at a similarity of 0.6823 , and may or may not be related to the volcanic province which generated group $A$. The subgroup in group A of Tcty1, Tctm1, Tcty3, Tcth 2 and Tcth3 may also represent tephras from another chemically distinct volcanic source. The tuff of Mission Creek two (Tctm2), in group $B$, also has a distinct chemistry among the units in this sequence.

Lacking substantial field evidence for the genesis of the Chumstick tuffs from more than one volcanic field, the presence of at least two and as many as five to six 
chemically distinct sources can be postulated by the low similarites of groups and individual tuff beds in the dendrogram.

Rare earth patterns of tuffs from the two major groups, (Figures 18 and 19) support the presence of at least two chemically different volcanic sources. Group A is enriched in both light rare earth elements (LREE) La, Ce, and Sm, and heavy rare earth elements (HREE) Tb, $\mathrm{Yb}$, and Lu relative to group $B$. The plot of Eu versus K (Figure 20) separates the tephra samples into the same two groups. Group $B$ is more enriched in $K$ and depleted in Eu relative to group $A$. The slope of the LREE is the same for both groups. The major distinctions between the two patterns is the abundance of REE, the Eu anomaly, and the positive slope of the HREE in group $A$ and a negative slope for the HREE in group $B$.

Even with these variations in REE signatures, it is conceivable that these contrasts are due to differentiations within a single magma system rather than a result of two or more chemically different magmas. The use of trace elements to model petrogenesis of highly silicic rocks is complex. Silicic melts can be produced by melting a variety of source rocks. Futher, there is a lack of knowledge about how distribution coefficients for trace elements change in minerals and melts with changing temperatures, pressures and compositions. Other possible factors 


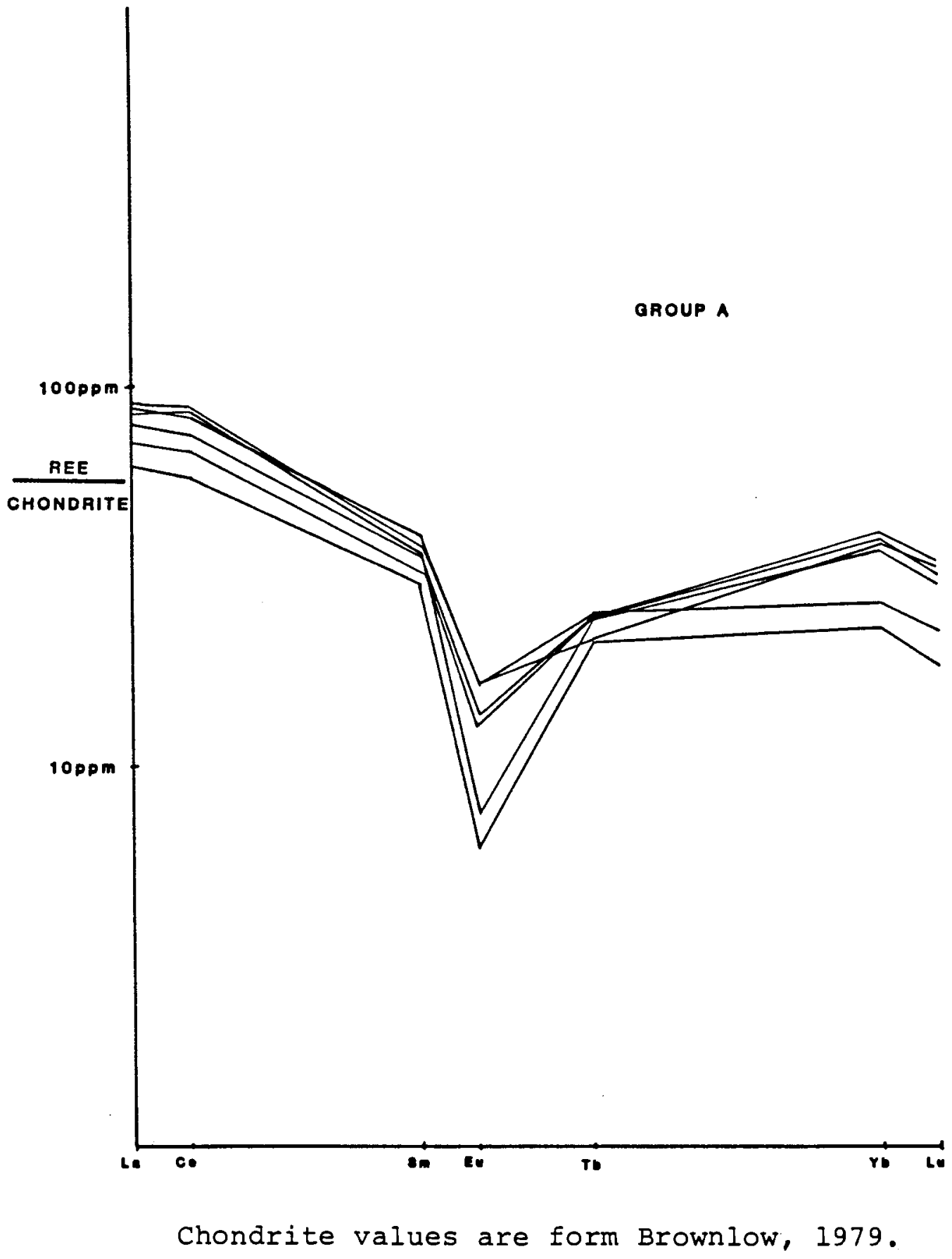

Figure 18. Chondrite-normalized plot of the rare-earth element concentrations from the tuff beds present in Group $A$ of the cluster analysis dendrogram. 


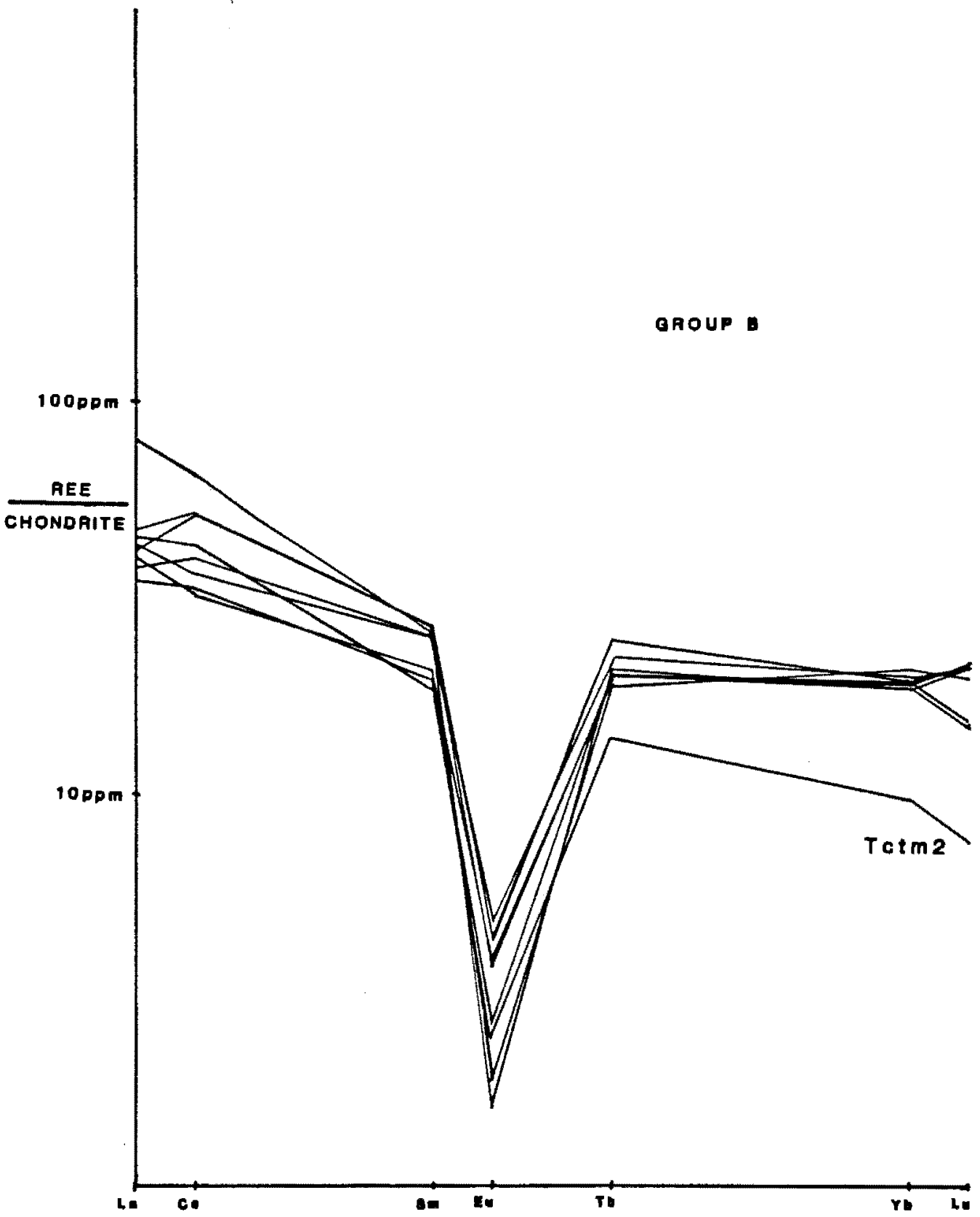

Chondrite values are from Brownlow, 1979.

Figure 19. Chondrite-normalized plot of the rare-earth element concentrations from the tuff beds present in Group $B$ of the cluster analysis dendrogram. 


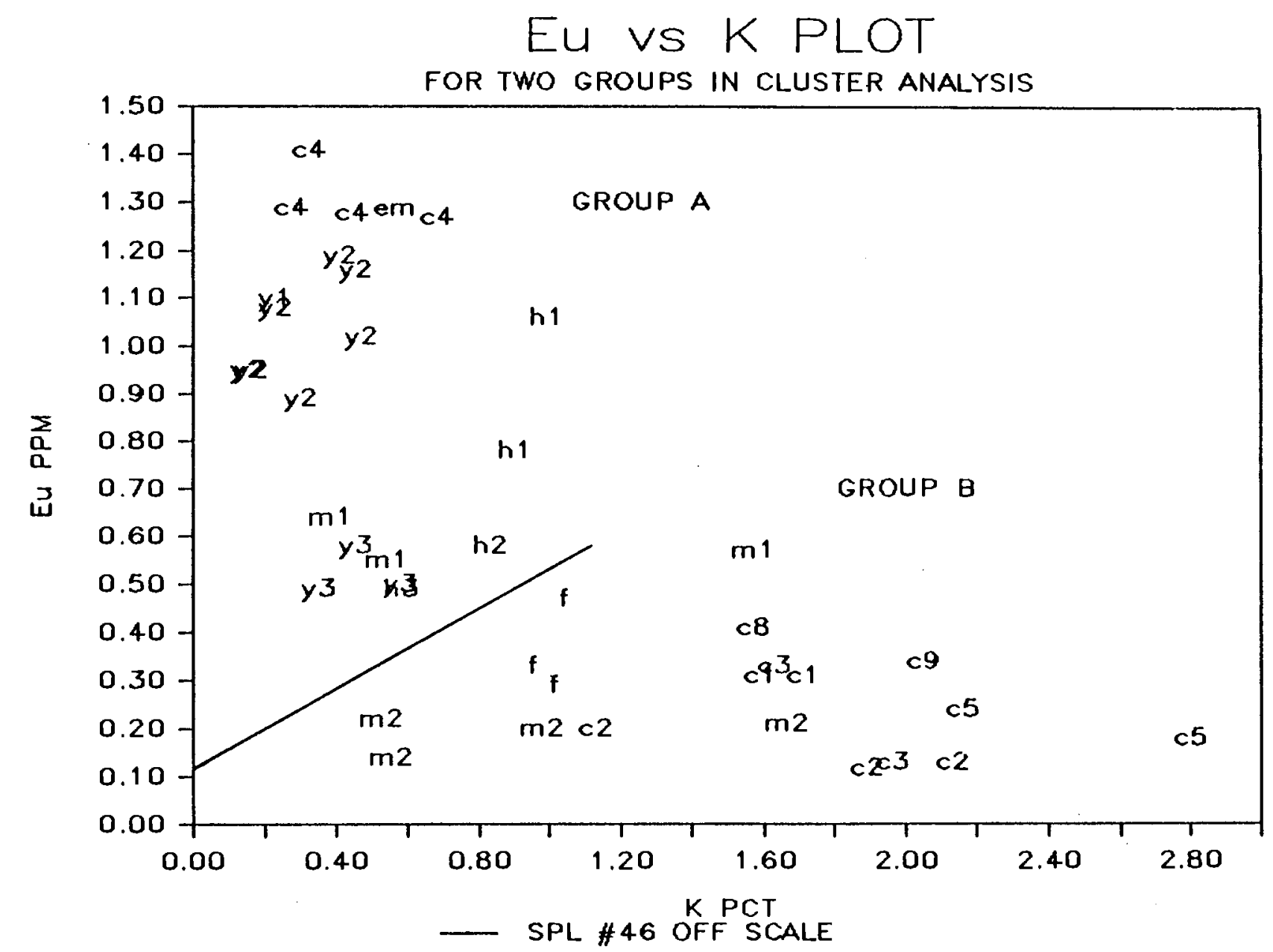

Figure 20. Eu versus $K$ plot for the Chumstick tuff beds present in Group $A$ and Group $B$ of the cluster analysis dendrogram. 
include: magma mixing, liquid immiscibility, assimilation of wall rock, evolution of volitiles (Hildreth, 1979; Henderson, 1984).

The data necessary to convincingly eliminate possible petrogenic models which would genetically relate the tephras of group A to group B is beyond the scope of this study.

Because there is no field evidence to separate the Chumstick tuff beds from the two groups as Sarna-Wojcicki (1979) had, I must speculate as to the similarity ranges. The similarities of samples from individual beds range down to 0.820 . The similarities between tuff beds in the same group range down to 0.7094 . Similarities less than 0.700 suggests that the tuffs are not from the same volcanic province, or that the units may be altered or contain detrital material. Similarities ranging from $0.700-0.820$ suggests that the tephras are genetically related to the same volcanic province. Similarities greater than 0.820 indicate a possible correlation. Different tephras from the same vent and tephras erupted from the same volcanic field tend to have similar chemistry (Izett and others, 1970; Izett and others, 1972; Kittleman and others, 1971; Sarna-Wojcicki, 1976 and 1979). This is exemplified by the similarities of Tctcl, Tctc2, Tctc3 and Tctc5 in Figure 7. As Sarna-Wojcicki (1984) discusses the nassumption of the compositional uniqueness of vol- 
canic glass of tephras derived from individual eruptions seems reasonable in view of the many factors that probably affect magma generation and differentiation."

The usefulness of tuff beds as correlation tools, utilizing mainly trace element chemistry of bulk samples, is related to how distinct their chemistry is. The tuff beds present in group $A$ of the cluster analysis dendrogram are essentially not intermixed and neither are Tctm2 and Tctf in group $B$. This absence of intermixing of samples from different tuff beds indicates the chemistry of these units are distinct within the local stratigraphic sequence.

Because Tctm 2 does not tie to any other tuff bed until approximately 0.700 in the dendrogram, it is one of the most chemically distinct of the Chumstick tuffs. The uniqueness of Tctm2 is clearly shown in the REE plot of the group B tephras (Figure 19) as Tctm2 plots separately from the rest of the tephras. Two of the Tctm2 samples are from the lower pumice rich zone taken at different localities. One is from the underlying smectite, and the other is from the upper crystal rich zone (see Appendix E). Even with the chemical variations that exist between the three parts of the tuff bed, the chemistry of the tephra was distinct enough that the samples clustered together in the dendrogram.

The chemistry of the tuff of Fairview Canyon is 
also distinct from the other Chumstick tuffs. The fact that the altered sample of Tctf, from the bleached zone, ties with the other two samples of Tctf reinforces this. Even with a chemically distinct tephra, caution should be exercised when it has been altered beyond diagenetic effects or if detrital admixture is present. For example, the position of the altered sample from Tcthl in the dendrogram in no way suggests any similarity in chemistry with the unaltered sample from Tcthl. However the ternary diagram, the $\mathrm{K}$ versus $\mathrm{Eu}$ plot and the scatter plot (Figures 8,20 and 6) plot the two samples together. Three samples of Tctc 2 were submitted to the cluster analysis. The basal portion of the tuff in one locality was not exposed so a sample was taken approximately one half a meter above the base. Fine detritus was visible in hand sample. This sample tied with the other two Tctc2 samples at a much lower similarity value.

Because of the bulk sample analysis employed, the problem of detrital admixture is a major consideration. This is particularily true when the host rocks are continental sediments. Air-fall ash which falls into lacustrine or floodplain environments stands an excellent chance of preservation with little detrital admixture. However, the longer the pyroclastic material is in the transportation environment, the more chance exists for inclusion of foreign debris. Detritus may also occur 
in the form of earlier tephra products. This can easily result if topography exists within the basin. Ash-falls may accumulate at different elevations and continually be reworked mixing with clastic sediments and newly deposited tephra (Luft, 1985). The preliminary look at detrital effects on the tephra chemistry (Table IX) indicate substantial detritus must be present before the chemistry of the tephra is significantly effected. However, before this conclusion is substantiated a much more in depth study would be required. The effect of detritus on the tephra chemistry is related to the concentration of trace elements in the detritus. Trace elements can be concetrated in some accessory minerals, but relatively sparse in quartz and feldspars (Henderson, 1984). The size fraction of the detritus may also have a considerable impact on the trace element content.

The intermixing of samples from tuff beds known to be different in group $B$ of the dendrogram indicate that the statistics employed are unable to separate and group the tephras based on their chemistry. This does not mean that these units cannot be separated based on accessory minerals or the concentrations of two or more elements, but as a whole their chemistry is not distinct. Thus their use as correlation tools are not as desirable as units which have a more distinctive chemistry. Those units which have a distinctive chemistry can be more easi- 
ly identified, and they may be able to undergo mild alteration or contain minor detrital admixture while maintaining a recognizable chemical signature.

Two factors could result in the chemical similarity found between many of the Clark Canyon tuff beds (Group B). The tuff beds may have erupted from the same volcanic vent or field resulting in similar chemistry. Or, detrital admixture may have altered their chemistry reflecting the chemistry of the arkosic sediment. However, the chemistry of three Chumstick sediment samples from Byrnes (1985) plot distinctly separate from the tuff beds (Figure 21). Two samples from Tctc6 plot with the other tuffs of Clark Canyon and two Tctc6 samples plot much closer to the sediment samples in Figure 21 . The inability to reproduce the chemistry of Tctc6 may thus be attributable to detrital effects.

It is not without a jaundice eye that the stratigrapher should view these units. Not only must he contend with the effects of devitrification and mechanical sorting on the chemistry of the tephra, but the prospects of obtaining a pure uncontaminated sample of a tuff bed may be rare in the subaerial environment.

The stratigraphic potential of these units is too great to simply pass them by because of possible problems with their characterization. The reproducibility of chemistry from multiple samples of a unit along bedding will 


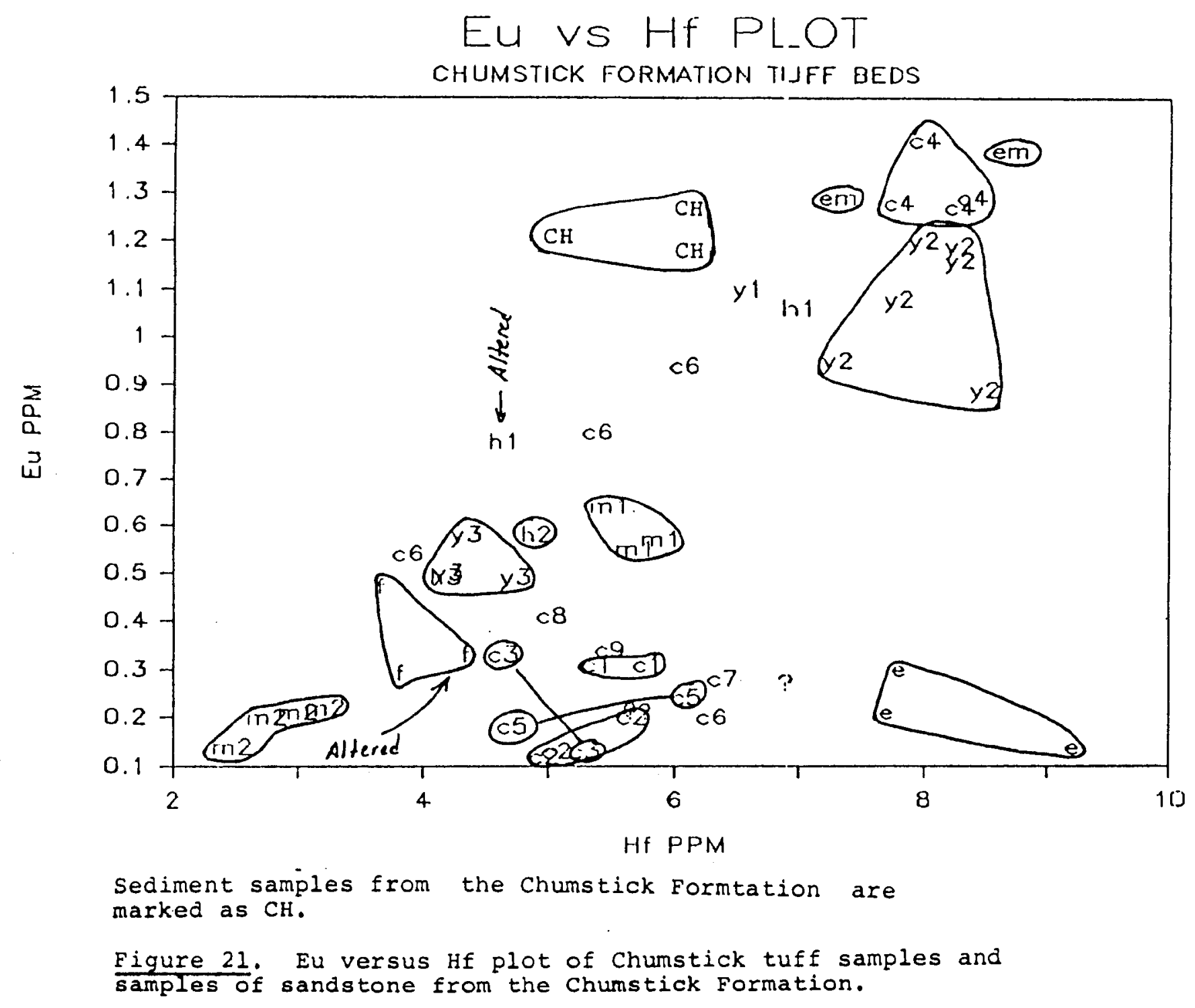


indicate its usefulness as a marker horizon. Probably not all tuff beds present in a basin can be used as chemical marker horizons. The tuff of Clark Canyon six (Tctc6) is such an example. Since its chemistry was not adequately reproducible, probably a result of detrital admixture, its use as a marker bed at this time is restricted to the distance it can be traced in the field.

Even though the chemistry of a tephra may be distinct, the multiple factors which can effect the bulk chemistry of a devitrified tuff bed may create large enough variances in the chemistry that the bed may not be able to be distinquished from tuff beds with similar chemistry. The majority of the Chumstick tuff beds were distinguishable on the basis of their bulk chemistry. As a result, exposures of tuff beds of uncertain stratigraphic postion were correlated with distant tuff beds present in the Chumstick Formation. 


\section{SUMMARY}

1. Volcanic ash preserved in continental and marine sedimentary rocks may form potential inter and intrabasin marker horizons. This study examined the feasibility of using field criteria and trace element chemistry to distinguish and to correlate tuff beds within a continental basin.

2. The tuff beds are preserved in continental sedimentary rocks of the Chumstick Formation, which is an 8,700 $m$ sequence of interbedded arkosic sandstone, shale and conglomerate deposited in fluvial to lacustine environments of middle Eocene age. The formation is confined to the northwest-trending Chiwakum graben in central Washington which subsided between 46-40 m.y.b.p.

3. Based on whole rock chemical analysis from five of the tuff beds, the Chumstick tuffs are rhyolitic in composition ranging from 76-79 \& $\mathrm{SiO}_{2} \cdot$ Individual tuff beds are olive-grey on fresh surfaces and weather white. They are cherty and break with a blocky subconchoidal fracture. Their resistance to erosion makes them excellent field marker beds.

4. The tuff beds have been diagenetically altered to a quartz, clinoptilolite or heulandite and smectite assemblage.

5. Ten elements were used to distinguish between the tuff beds. Of these ten elements step-wise discriminant analysis shows Sc to be the most discriminatory followed 
in decreasing order of ability to discriminate by Eu, $\mathrm{Fe}, \mathrm{Hf}, \mathrm{Yb}, \mathrm{La}, \mathrm{Ta}, \mathrm{Sm}, \mathrm{Th}$, and U.

6. The chemistry of the majority of the tuff beds is here shown to be reproducible along bedding and distinct enough to be used as a fingerprint for individual beds. 7. No repetition of tuff beds is found in the Chumstick Formation.

8. The usefulness of tuff beds as correlation tools, utilizing mainly trace element chemistry of bulk samples, is related to their chemical uniqueness. Those units which have a distinctive chemistry can be easily identified, and they can be recognized inspite of undergoing mild alteration or containing minor detrital admixture. 9. Scattered exposures of tuffs of uncertain stratigraphic position were compared to the established tephrostratigraphy of the basin. The tuffs of Horse Lake Mountain two and three (Tcth2 and Tcth3) are the same, and they correlate with the third tuff in Yaxon Canyon (Tcty3). The tuff of Clark Canyon four (Tctc4) correlates with the tuff exposed in the upper East Fork of Mission Creek (Tctem).

10. The tuff of Horse Lake Mountain one (Tcth1) is chemically different from the three Yaxon Canyon tuffs. It is probably a previously unrecognized tuff bed in the Chumstick Formation projecting stratigraphically between the tuff of Fairview Canyon and the tuff of Yaxon Canyon 
three (Tctf and Tcty3). The addition of Tcthl to the stratigraphy brings to 19 the total number of tuffaceous horizons in the Chumstick Formation.

11. Cluster analysis suggests that the Chumstick tuffs are from at least two chemically different volcanic sources. One group is relatively enriched in rare earth elements compared with the other. Relative amounts of $K$ versus Eu strengthen this division. However, the present data does not exclude the possibility that these chemical differences are the result of differentiation. 12. For the ten elements used, similarity values for the Chumstick tuff beds less than 0.700 indicate that the tuffs are not from the same volcanic source. Similarity values between $0.700-0.820$ suggest that the tuffs may be genetically related to the same source, and values greater than 0.820 indicate a possible correlation may exist.

13. The source volcanics for the Chumstick tuffs are not known, but decreases in pumice and lithic clast size with distance in a few units and the association of mudflows with others suggest that the tuffs were derived from both northern and southern sources. 14. For the Chumstick Formation, the tuff beds provide local marker beds enabling stratigraphy and structure to be interpreted. The chemical signature of these units provides the basis on which the units can be traced over 
broad areas in the basin. Correlations of tuff beds were obtained over distances of $41 \mathrm{~km}$.

15. As a consequence of this study, a reference tephrostratigraphy is established for the middle Eocene in central Washington. 
Alexander, F., 1956, stratigraphic and structural geology of the Blewett-Swauk area (M.S. thesis): Seattle, Univ. Wash., $62 \mathrm{p}$.

Borchardt, M.E., Harward, M.E., Schmitt, R.A., 1971, Correlation of volcanic ash deposits by activation analysis of glass separates: Quat. Res., V. 1 , p. $247-260$

Borchardt, M.E., Norgren, K.A., Harward, M.E., 1973, Correlation of ash layers in peat bogs of eastern Oregon: G.S.A. Bull, v. 84, p. 3101-3108

Brownlow, A.H., 1979, Geochemistry: Englewood Cliffs, N.J., Prentice Hill, 498 p.

Byrnes, M.E., 1985, Providence study of late Eocene arkosic sandstones in southwest and central Washington (M.S. thesis): Portland, Portland State University, $65 \mathrm{p}$.

Buza, J.W., 1979, Dispersal patterns and paleogeographic implications of lower middle Tertiary sedimentary rocks in portions of the Chiwaukum graben, eastcentral Cascade Range, Washington, (M. S. thesis): Seattle, University of Washington, $40 \mathrm{p}$.

Carey, S.W., 1958, The tectonic approach to continental drift. In Carey, S.W., editor, 1958, Continental drift: University of Tasmania.Geology Department Symposium 2, p. 177-355.

Chappell, W.M., 1936, Geology of the Wenatchee quadrangle (Ph.D. thesis): Seattle, Univ. of Wash., 249 p.

Crerar, D.A., Williams, L.A., Parks, G.A., 1985, Silica diagenesis, I. Solubility controls: Jour. of Sed. Pet., v. 55, no.3, p. 0301-0311

Crowell, J.C., 1974, Origin of Late Cenozoic basins in Southern California. In Dickison, W.R., editor, 1974, Tectonics and sedimentation: Society of Economic Paleontology and Mineralogy Special Pub. 22 , p. 190-204

Davis, J.C., 1973, Statistics and data analysis in geology: New York, New York, John Wiley \& sons, 550 p. 
Evans, J.E., 1986, Influence of syndepositional tectonics on fluvial facies in a Tertiary wrench-fault basin, Chumstick Formation, Cascade Range, Washington: S.E.P.M. Annual Midyear Meeting Abstracts, v. 3.

Fisher, R.V., and Schmincke, H.U., 1984, Pyroclastic rocks: New York, New York, Springer-Verlag, 472 p.

Flanagan, F.J., 1976, Descriptions and analysis of eight new U.S.G.S. rock standards: U.S. Geol. Survey Professional Paper 84, 192 p.

Gresens, R.L., Whetten, J.T., Tabor, R.W., Frizzell, X.A., Jr., 1977, Tertiary stratigraphy of the central Cascades Mountains, Washingon State: in Brown E. H. and Ellis, R. C., eds., Geologic excursions in the Pacific Northwest Geological Society of America, Field Guide Annual Meeting, Seattle 1979, p. $84-126$

Gresens, R.L., Naeser, C.W., Whetten, J.T., 1981, Stratigraphy and age of the Chumstick and Wenatchee Formations-Tertiary fluvial and lacustrine rocks, Chiwaukum graben, Washington; Summary: Geological Society of America Bulletin, v. 92, no. 5, part I, p. 233-236; Part II, card 3, p. 841-876

Gresens, R.L., 1982, Early Cenozoic geology of central Washington State: I. Summary of sedimentary, igneous, and tectonic events: Northwest Science, Vol. 56 , no. 3, p. 218-229

Gresens, R.L., 1982a, Early Cenozoic geology of central Washington State: II. Implications for plate tectonics and alternatives for the origin of the Chiwaukum Graben: Northwest Science,v. 56, no. 4, p. 259-267

Gresens, R.L., 1983, Geology of the Wenatchee and Monitor Quadrangles, Chelan and Douglas Countis, Washington: State of Washington Bull. 75, 75 p.

Henderson, P., 1984, Rare earth element geochemistry: New York, New York, Elsevier, 510 p.

Hildreth, W., 1979, The Bishop Tuff: evidence for the origin of compositional zonation in magma chambers: Geol. Soc. Amer. Sp. Paper 180, p. 43-75 
Hildreth, W., and Mahood, G., 1985, Correlation of ashflow tuffs: Geol. Soc. Amer. Bull., v. 96, p. 968974

Huff, W.D., 1983, Correlation of Middle Ordovician K-Bentonites based on chemical fingerprinting: Jour. of Geology, v. 91, p. 657-669

Iijima, A., and Tada, R., 1981, Silica diagenesis of Neogene diatomaceous and volcaniclastic sediments: Sedimentology v. 28 , p. 185-200

Izett, G.A., Wilcox, R.E., Powers, H.A., Desborough, G.A., 1970, The Bishop Ash Bed, a Pleitsocene marker bed in the Western United States: Quat. Res. v. 1, p. $121-132$

Izett, G.A., Wilcox, R.E., Borchardt, G.A., 1972, Correlation of a volcanic ash bed in Pleistocene deposits near Mount Blanco, Texas, with the Guaje Pumice Bed of the Jemez Mountains, New Mexico: Quat. Res. v. 2 , p. 554-578

Kano, K., and Taguchi, K., 1982, Experimental study on the ordering of opal-CT: Geochemical Jour. v. 16, p. $33-41$

Kano, K., 1983, Ordering of opal-CT in diagnesis: Geochemical Jour., v. 17, p. 87-93

Kittleman, L.R., Randle, K., Goles, G.G., 1971, Geochemical and petrological characterization of ash samples from Cascade Range volcanoes: Quat. Res. v. 1, p. 261-282

Laravie, J. A., 1976, Geological field studies along the eastern border of the Chiwaukum graben, central Washington (M.S. thesis): Seattle, University of Wash. $56 \mathrm{p}$.

Luft, S.J., 1985, Airfall tuff in the Browns Park Formation, northwest Colorado and northeastern Utah: The Mountain Geologist, v. 22, no. 3, p. 110-127

Lupe, R.D., 1971, Stratigraphy and petrology of the Swauk Formation in the Wenatchee Lake area (M.S. thesis): Seattle, University of Wash. 27 p.

Maitre, R.W., 1982, Numerical Petrology: New York, New York, Elsevier Scientific Publishing Co., $281 \mathrm{p}$. 
Mumpton, F.E., 1960, Clinoptilolite redefined: The American Mineralogist, V. 45, p. 351-369

Nie, N.H., Hull, C.H., Jenkins, J.G., Steingrenner, K., and Brent, D.H., 1975, statistical package for the social sciences (2nd ed.): New York, McGrawHill, 675 p.

Page, B.M., 1939, Geology of a part of the Chiwaukum quadrangle (Ph. D. thesis): Stanford, Ca., Stanford University 203 p.

Powers, H.A., and Malde, H.E., 1961, Volcanic ash beds as stratigraphic markers in basin deposits near Hagerman and Glenns Ferry, Idaho: U.S. Geologic Survey Prof. Paper 424-B p. B-167-B-170

Rosenkrans, R.R., 1936, Stratigraphy of the Ordovician bentonite beds in south-western Virginia: Va. Geol. Survey Bull. 46, p. 85-111

Russel1, I.C., 1900, A preliminary paper on the geology of the Cascade Mountains in northern Washington: U.S. Geol. Survey, Twentieth Ann. Rept., v. 20, p. $89-210$

Sarna-Wojcicki, A.M., and others, 1976, Correlation of Late Cenozoic tuffs in the central coast ranges of California by Means of trace and minor-element chemistry: U. S. Geological Survey Prof. Paper 972,40 p.

1979, Chemical correlation of some Late Cenozoic tuffs of northern and central California by neutron activation analysis of glass and comparison with $x$-ray fluorescence analysis: U. S. Geological Survey Prof. Paper 1147, 15 p.

1984 , Chemical analyses, correlations, and ages of upper Pliocene and Pleistocene ash layers of east central and southern California: U. S. Geological Survey Prof. Paper 1293, 40 p.

Sheridan, M.F., 1979, Emplacement of pyroclastic flows: A Review. Geol. Soc. Amer. Sp. Paper 180, 125-136

Slaughter, M. and Earley, J.W., 1965, Mineralogy and geological significance of the Mowry Bentonites, Wyoming: Geol. Soc. Amer. Sp. Paper 83, 116 p.

Smith, G.O., 1904, Mount Stuart quadrangle: U.S. Geol. Survey Folio 106,11 p., 4 maps. 
Tabor, R.W., Frizzell, V.A., Jr., Whetten, J.T., Swanson, D.A., ByerlY, G.R., Booth, D.B., Hetherington, J.J., Waitt, R.B., Jr., 1980, Preliminary geologic map of the Chelan $1: 100,000$ quandrangle, Washington: U.S. Geological Survey Open-file Map 80-841, $46 \mathrm{p} ., 1$ map, scale $1: 100,000$

Tabor, R.W., Waitt, R.B.,Jr., Frizzell, V.A., Jr., Swanson, D.A., Byerly, G.R., Bentley, R.D., 1982, Geologic map of the Wenatchee $1: 100,000$ quandrangle, central Washington: U.S. Geological Survey Miscellaneous investigations Map 1-1311, 25p. 1 map, scale $1: 100,000$.

Waters, A.C., 1930, Geology of the southern half of the Chelan quadrangle (Ph.D. thesis): New Haven, Tale Univ., $265 \mathrm{p}$.

Westgate J.A., and Fulton, R.J., 1975, Tephrostratigaphy of Olympia Interglacial sediments in south-central British Columbia, Canada: Canadian Jour. Earth Sci., v. 12, p. 489-502

Whetten, J.T., 1980, Preliminary bedrock geologic map of the Chiwaukum $4 \mathrm{NW}$ quadrangle, Chiwaukum graben, Washington: U.S. Geologic Survey Open-File Report 80-456, Scale $1: 24,000$.

Whetten, J.T., 1980a, Preliminary bedrock geologic map of the Chiwaukum 4 SE quadrangle: U.S. Geological Survey Open-File Report $80-723$, scale $1: 24,000$.

Whetten, J.T., and Laravie, J.A., 1976, Preliminary geologic map of the Chiwaukum 4 NE quadrangle, Chiwaukum graben, Washington: U.S. Geological Survey Miscellaneous Field Studies Map MF-794, scale 1;24,000.

Whetten, J.T., and Waitt, R.B., Jr., 1978, Preliminary geologic map of the Cashmere quadrangle, Chiwaukum lowland, Washington: U.S. Geological Survey Miscellaneous Field Studies Map MF-908, scale 1:24,000.

Willis, C.L., 1950, Geology of the northeastern quarter of the Chiwaukum quadrangle (Ph.D. thesis): Seattle, Univ. of Wash., $158 \mathrm{p}$

Willis, R., 1903, Physiography and deformation of the Wenatchee-Chelan district, Cascade Range, Wash.: U.S. Geol. Survey Prof. Paper 19, p. 43-101 
APPENDIX A

\section{STEP-WISE DISCRIMINANT ANALYSIS}

Step-wise discriminant analysis is an option of the Statistical Packages for the Social Sciences (SPSS) program Discriminant (Nie and others, 1975). Samples from an individual tuff bed are used to define a group. With the chemical analysis of a set of samples from known groups, one can use step-wise discriminant analysis to establish the order in which the nineteen elements obtained by INAA best distinguish between the groups.

The criterion used in the step-wise method is Wilks' lambda. A multivariate $F$ ratio is used to test the separation between group centroids. The $F$ ratio is the division of the between-group mean square by the withingroup mean square. Lambda is the inverse of the $F$ ratio. The more discriminating the element the smaller lamda is and the larger the $\mathbf{F}$ ratio. F ratios are calculated for each element. The element with the largest $F$ ratio and consequently lowest lambda value exits from the pool of elements and enters into the pool of better discriminators. Calculations are performed on the remaining set of variables to see which one is the next best discriminator.

Before an element is selected, its partial F ratio must be sufficiently large. The partial F ratio is a test for the amount of group centroid separation the newly 
selected element adds beyond the amount produced by the previously removed elements. The partial $\mathrm{F}$ ratio must be equal to or larger than 1.0 or the new variable fails to enter. As each element enters, partial $F$ ratios are performed on those already selected. As the list of selected elements grows, it is possible that a previously selected element would no longer be making a contribution to the separation of the groups. A default value of 1.0 is set to remove any previously selected elements. (Nie) and others, 1975) 


\section{APPENDIX B}

\section{DISCRIMINANT ANALYSIS}

Discriminant analysis takes a set of groups with known variables and defines the groups based on these variables. In the case of the Chumstick tuffs, each individual tuff bed is a group made up of indivdual samples, and the variables are the elements. Discriminant analysis has the ability to take samples of unknown correlation and place them within the already defined groups. When a sample of unknown correlation is submitted to the analysis it will be correlated with the group it most closely resembles. If the sample is from a tephra which is not a member of the known stratigraphy, a correlation will be forced which could be misleading. Thus, discriminant analysis should only be used when the entire set of groups is defined. Consequently, it is an excellent technique for correlating tuff exposures in a single basin with a known stratigraphy.

Table IV shows the canonical discriminant functions which are used in the discriminant analysis in this study. The eigenvalues and their associated canonical correlations indicate the relative ability of the function to distinguish between the Chumstick tuff beds. The percent of discriminating power is shown for each function and totaled as the power of the next function is added. 
TABLE IV

CANONICAL DISCRIMINANT FINCTIONS

\begin{tabular}{|c|c|c|c|c|c|c|c|c|c|c|}
\hline FUNCTION & EIGENALUE & $\begin{array}{l}\text { PERCENT OF } \\
\text { UARIANCE }\end{array}$ & $\begin{array}{l}\text { CUMULATIVE } \\
\text { PERCENT }\end{array}$ & $\begin{array}{l}\text { CANDNICAL } \\
\text { CORRELATION }\end{array}$ & $:$ & $\begin{array}{l}\text { ATIER } \\
\text { FLNCTION }\end{array}$ & HILKS' LAYBOA & CHI-SQLARED & D.F. & SIGNIFICANCE \\
\hline & & & & & : & 0 & 0.0000001 & 485.76 & 135 & 0.0000 \\
\hline 1 & 115.22669 & 64.10 & 64.10 & 0.9956888 & $:$ & 1 & 0.0000082 & 345.48 & 112 & 0.0000 \\
\hline 2 & 37.34201 & 20.77 & 84.87 & 0.9868733 & : & 2 & 0.0003145 & 237.90 & 91 & 0.0000 \\
\hline 3 & 15.36742 & 8.55 & 93.42 & 0.9689701 & : & 3 & 0.0051478 & 155.44 & 72 & 0.0000 \\
\hline 4 & 6.28482 & 3.50 & 96.91 & 0.9289316 & : & 4 & 0.0375006 & 96.86 & 55 & 0.0004 \\
\hline 5 & 2.83902 & 1.58 & 98.49 & 0.8599515 & : & 5 & 0.1439656 & 57.17 & 40 & 0.0383 \\
\hline 6 & 1.40201 & 0.78 & 99.27 & 0.7639909 & : & 6 & 0.3458068 & 31.32 & 27 & 0.2560 \\
\hline 7 & 0.68050 & 0.38 & 99.65 & 0.6363478 & : & 7 & 0.5811279 & 16.01 & 16 & 0.4521 \\
\hline 8 & 0.39051 & 0.22 & 99.87 & 0.5299416 & $:$ & 8 & 0,8080628 & 6.28 & 7 & 0.5067 \\
\hline 9 & 0.23753 & 0.13 & 100.00 & 0.4381064 & $:$ & & & & & \\
\hline
\end{tabular}


The right side of the table shows the Wilks' lambda and the associated chi-squared tests of statistical significance. Before any of the functions were removed lambda is 0.0000001 . This indicates that a tremendous amount of discriminating power exists in the set of discriminants. 


\section{APPENDIX C}

\section{CLUSTER ANALYSIS}

Cluster analysis is a multivariate technique which can be used when the entire stratigraphy is not defined. In this analysis, no assumptions are made about the data. The tephra samples are not preassigned to membership in a group as in discriminant analysis. In cluster analysis, a group is defined as those samples which have been tied together after analysis because of their similarity to each other. The major advantage of cluster analysis over discriminant analysis is that it can tell if an unknown is not likely to belong to any predefined group (Maitre, 1982). Similarity coefficients based on the ten chemical elements are calculated between each individual tuff. The similarity coefficient is taken from Sarna-Wojcicki, 1976

$$
d(A, B .)=\frac{\sum_{i=1}^{R_{i}} x_{i}}{N}
$$

Where $d\left(A . B_{.}\right)=d(B . A)=$. similarity coefficient for comparison between sample $A$ and sample $B$,

$i=$ element number

$\mathrm{n}=$ number of elements

$\mathrm{Ri}=\mathrm{X}_{\mathrm{i}} \mathrm{A} / \mathrm{X}_{i} \mathrm{~B}$ if $\mathrm{X}_{i} \mathrm{~B}>\mathrm{X}_{\mathrm{i}} \mathrm{A}$; otherwise $\mathrm{X}_{i} \mathrm{~B} / \mathrm{X}_{i} \mathrm{~A}$ $X_{i} A=$ concentration of element $i$ in sample $A$ $\mathrm{x}_{\mathrm{i}}^{\mathrm{B}}=$ concentration of element $\mathrm{i}$ in sample $\mathrm{B}$

The similarity coefficient is an average of the ratios of the elements in two tuff samples. Since the coeffi- 
cient is a ratio, it is always less than or equal to 1.00. An identical match produces a similarity coefficient of 1.00 .

The matrix of these similarity coefficients were then used for cluster analysis. The cluster analysis program is from Davis (1973). The linkage method used is weighted pair group averaging (w.p.g.a.). In w.p.g.a. each time an object is added to the group, the new average is calculated as the sum of the similarity measure of the new object and the previous group average divided by two. Once subjects are grouped together they are treated as single objects. Consequently, the group average is weighted in favor of the new object. As one can imagine, this does result in some distortion. In this analysis, tephra samples are broken out into their natural associations. 


\section{APPENDIX D}

\section{X-RAY DIFFRACTION PROCEDURES}

X-ray diffraction was performed on a General Electric XRD-5 D/F $x$-ray unit at Portland State University. The instrument uses a $\mathrm{Cu}$ target and a $\mathrm{Ni}$ filter. Samples were run at $40 \mathrm{KV}, 1,000$ counts per second with a 1.0 second time constant and at 2 theta per minute.

Samples of fracture coating zeolites were ground in a mortar and pestle and a powder sample holder was used for analysis.

Clay samples were disaggregated in water, and the suspended fraction was drawn off and dried on ceramic tiles. The tiles were used for the diffraction analysis. Samples were glycolated to determine smectite.

Thin section billets were used to identify the alteration assemblage in the tuffs. Heulandite was distinguished from clinoptilolite by heating the billets to $350 \mathrm{C}$ and reanalyzing them (Mumpton, 1960). 


\section{APPENDIX E}

DETAILED STRATIGRAPHY OF THE INDIVIDUAL TUFE BEDS

TUFE OE FAIRVIEW CANYON

The tuff of Eairview Canyon (Tcte) is the stratigraphicly lowest tuff in the Chumstick Formation. Tctf is an olive-green crystal vitric tuff. It is white on weathered surfaces. It is poorly exposed; its occurances are shown in Figure 27 and Plate 1 . The tuff has been bleached white, possibly from hydrothermal fluids associated with nearby andesite intrusions, at its northern extent in the SE $1 / 4$ of the NE $1 / 4$ of sec. 22, T. 23 N., R.19E. The tuff changes color to a common olive-green color to the south. Carbon fragments are present and stilbite lines the fracture surfaces. Biotite crystals are abundant in the tuff. The tuff is 2 to $21 / 2 \mathrm{~m}$ thick at an exposure in the $\mathrm{SW} 1 / 4$ of the $\mathrm{SW} 1 / 4$ of sec. 23 , T. $23 \mathrm{~N}$, R. 19E.

\section{YAXON CANYON TUFFS}

Three tuff beds in Yaxon Canyon south of the Wenatchee River were first mapped by Gresens (1983). Two of the units, and a tuffaceous sandstone which may correlate to the third, where found on the north side of the We- 
TEPHROSTRATIGRAPHY

OF THE CHUMSTICK FORMATION

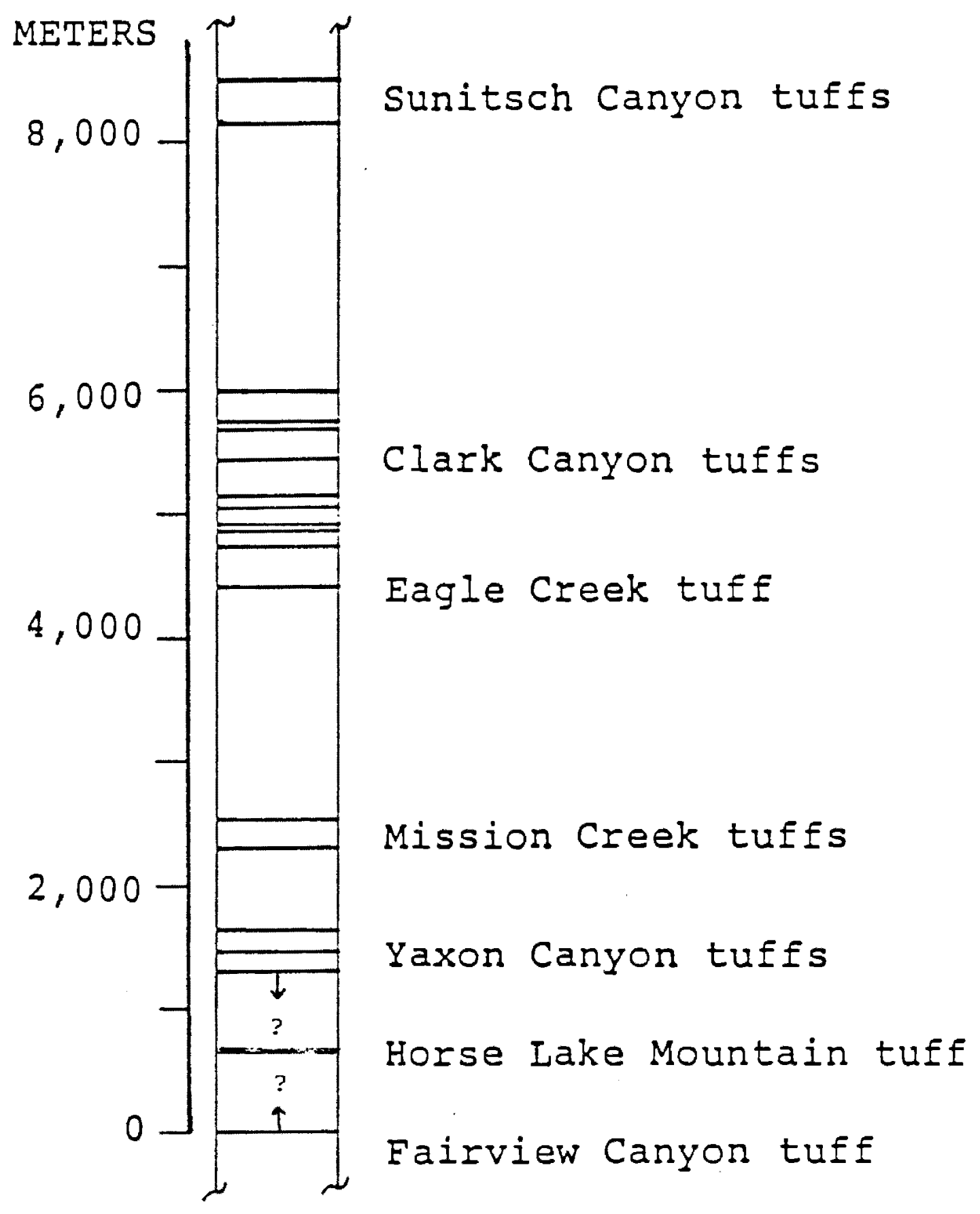

SOURCES: Evans 1985, Gresens 1983

Figure 17. Tephrostratigraphy of the Chumstick Formation. 
natachee River (Plate 1, Figures 28 - 30). The outcrops at the mouth of Hay Canyon in sec. 32 T.24N., R.19E. offer the best exposures for the two older units, Tcty 2 and Tety 3.

The lower tuff of Yaxon Canyon, Tcty 3 , is a greenishgrey vitric tuff and can be traced intermittently for $9.5 \mathrm{~km}$ along the east side of Yaxon Canyon and northward. The tuff is white on weathered surfaces. The best exposure of Tcty 3 is found just east of Hay Cayon in sec. 32 below the radio tower at an elevation of $378 \mathrm{~m}$. Here it is $3 \mathrm{~m}$ thick. Fractures are veneered with stilbite, and rare carbon fragments are present. Abundant detritus is found in the upper $50 \mathrm{~cm}$. This tuff bed is poorly exposed south of the Wenatchee River. At a fair exposure in the NE $1 / 4$ of sec. 16 , it has weathered to small white angular Eragments 7 to $12 \mathrm{~cm}$ in size. Tcty 3 is approximately $11 / 2 \mathrm{~m}$ thick at this location.

The middle tuff of Yaxon Canyon (Tcty2) is a yellowbrown vitric tuff and can be traced a total distance of $10.5 \mathrm{~km}$. It is best exposed along an abandoned irrigation canal at the east side of the mouth of Hay Canyon in the NW $1 / 4$, SW $1 / 4$, sec. $32 \mathrm{~T} 24 \mathrm{~N}$ Rl9E where the tuff is 2 m thick. Limonite pervasively coats fracture surfaces. Liesegang banding is present on fresh surfaces. Black spots less than $1 \mathrm{~mm}$ occur throughout the unit and are probably oxidized magnetite crystals. The tuff bed is 
generally devoid of detritus even near its top. Evidence of Eluvial transport is also lacking. Across Hay Creek the bed is offset by faulting. The tuff bed is offset to the northwest as it reappears on the west side of Hay Canyon. The tuff is blue-green where it crosses the drainage below the power lines in the $\mathrm{SE} 1 / 4$ of the NW $1 / 4$ of sec. 32 T.24N.R.19E. Here it is very fine grained with no detritus in its lower $30 \mathrm{~cm}$. Scattered carbon fragments are present.

The next best exposure of the middle tuff is in Yaxon Canyon in a cut through a dip slope in sec. 16. Top and bottom contacts are not exposed here; its thickness is estimated at one meter. It maintains the same yellow brown color as its northern outcrop, and where found it is a light blue green on Eresh rock surfaces. Occasional carbon and leaf fragments are present. In the SE $1 / 4$ of the SW $1 / 4$ of sec. 21 , Tcty 2 is $3 / 4 \mathrm{~m}$ thick and is underlain by $60 \mathrm{~cm}$ of carbonaceous sandy siltstone.

The upper tuff bed (Tctyl) is a light-grey vitric tuff. It crops out for a distance of $10 \mathrm{~km}$. At the $\mathrm{SE}$ $1 / 4$ of the $\mathrm{NW} 1 / 4$ of the $\mathrm{SE} 1 / 4$ of sec. 16 in Yaxon Canyon the tuff is $1.75 \mathrm{~m}$ thick. Biotite flakes and carbon horizons of stems and leaf hash are present. Shallow trough, cross bedding exist in the upper $30 \mathrm{~cm}$ of the tuff, and detrital content increases within this interval. The 
tuff weathers white and has a limonite coating on fractures. Five cm of white clay lie immediatly below the cherty tuff. X-ray diffraction shows this clay to be a smectite, and it is probably a portion of the tephra which underwent different diagenesis.

To the south Tctyl is bleached white from the northwest side of the confluence of the drainage at the head of Yaxon Canyon in sec. 21 south. The unit's presence north of the Wenatchee River is inferred by the presence of a vitric sandstone approximately $40 \mathrm{~m}$ west of Tcty 2 .

\section{TUFES OF MISSION CREEK}

Two tuff beds are exposed in Mission Creek (Plate 1, Figures $28,30,33)$. The lower tuff bed, Tctml, is a blue-grey crystal vitric tuff and can be followed for a distance of $10 \mathrm{~km}$. It is white on weathered surfaces. The tuff exhibits a uniform character along bedding. An excellent exposure occurs along an irrigation canal in the SE $1 / 4$ of the NE $1 / 4$ of sec. $31, T 24 N$, Rl8E. It is $4.5 \mathrm{~m}$ thick here and overlies a muddy sandstone bed with traces of tree limbs preserved in the bedding planes. Limonite and manganese dioxide have stained fracture surfaces. The percentage of detritus steadily increases toward the top of the bed. The tuff is capped by a thin bed of organic rich siltstone. 
The next good exposure of the upper tuff is found as it reappears south of Cashmere in a canal cut in sec. 8. The tuff is about $5.5 \mathrm{~m}$ thick here, and has abundant detritus.

Tctml has weathered to small angular white chips at the surface of a dip slope on the east side of Mission Creek in sec. 20. Stilbite is present in vugs and fracture faces.

The lower tuff, Tctm2, is a light-grey, coarse grained, pumice lappili tuff. It can be traced for $8.5 \mathrm{~km}$. The tuff is present on the north side of the Wenatchee River where it outcrops for $2 \mathrm{~km}$ before dropping into ollala Canyon. It could not be found on the north side of ollala Canyon. An excellent outcrop occurs along an irrigation canal in the SE $1 / 4$ of the $N E 1 / 4$ of the $N E$ $1 / 4$ of sec. 31, T. $24 \mathrm{~N} ., \mathrm{R} .19 \mathrm{E}$. The canal cut exposes the tuff bed twice as it goes around a bend. The base of the northernmost exposure consists of a $75 \mathrm{~cm}$ thickness of white clay. In sharp contact above is a 2.75 to 3.0 m thick pumice rich white unit. Capping the pumice lappili zone is a 50 to $75 \mathrm{~cm}$ grey-green sandy vitric tuff. Twenty five cm of pebbly sandstone separate the sandy vitric tuff from a 2 m thickness of a very detrital rich green vitric tuff. The large amount of detritus in this upper vitric zone suggests that this deposit may be the latter reworking of the air-fall instead of a second erup- 
tion.

The tuff is a buff colored clay where it crops out south of Cashmere in the NW 1/4 of sec. 8. To the south it reappears on the north side of Woodring Canyon, where it resembles the outcrop in sec. 31 north of the Wenatchee River. Here the base is a $40 \mathrm{~cm}$ thick waxy white smectite which overlies $8 \mathrm{~cm}$ of greyish-green siltstone. Two and three forth meters of cherty tuff overlies the white clay. The chemistry of the smectite is very similar to that of the overlying chert, and this supports the interpretation that the clay is also the weathered product of the ash. The tuff is a tan-grey on fresh surfaces and weather white. Carbon fragments occur throughout the unit and at times accumulate in thin beds. White pumice clasts also occur sporadically throughout the unit but are concentrated in a $50 \mathrm{~cm}$ basal zone in sharp contact above the clay. Trough cross-lamination in the tuff suggests fluvial reworking. Farther to the south in Trip Canyon the tuff continues to show evidence of fluvial transport and reworking, and at its southern most point in Slawson Canyon it has been totally reworked into a flaggy sandstone (Gresens, 1983). 
TUFF OF EAGLE CREEK

The tuff of Eagle Creek (Tcte) is one of the most extensive and lithologically unique marker bed in the Chumstick Formation (Plate 1, Figures 31-33). It is a coarse grained pumiceous, crystal vitric tuff. This may be the prominent tuff described by waters (1930) and is certainly the "key bed" of Page (1939). Whetten and Laravie (1976) labeled it Ttl and mapped it on both limbs of the Eagle Creek anticline. Gresens (1977) named it the tuff of Eagle Creek.

An excellent exposure occurs on the east side of a north, northeast trending ridge in the $\mathrm{NW} 1 / 4$ of the SE $1 / 4$ of the SW $1 / 4$ of sec. 10, T. $25 \mathrm{~N}$, R. $18 \mathrm{E}$. Here Tcte is $19.5 \mathrm{~m}$ thick and exhibits many of the textures and structures described by Sheridan (1979) as being characteristic of pyroclastic flows. The tuff overlies a dark, $30 \mathrm{~cm}$ thick, finegrained, finely laminated sandstone, which caps a thick bed of conclomeratic arkose. The basal part of the ash flow has a wavy green flow structure present. In some instances, this structure is seen to flow around lithic clasts. Lithic clasts occur stratigraphically throughout the unit but are concentrated in a basal zone. This concentration of lithics is a common feature of pyroclastic flows. (Sheridan, 1979) 
The lithology of the clasts varies but the majority are coarse grained gneiss with some vein quartz. Dark gneissic clasts similar to the Ingalls gneiss are present along with coarse grained whitish clasts. Some of the white clasts have very coarse crystals of a bright green mica thought to be fugsite. Fugsite is an unusual mica, and the presence of a Fugsitic white gneiss on the north side of Lake Wenatchee is worth noting (Paul E Hammond, oral communication 1985). Vertical jointing characterizes the lower two thirds of the ash-flow. The upper one third exhibits a more platy fracture. Thin lenses of reverse graded coarse crystals and lithic fragments are present in this platy zone. Sheridan (1979) describes inversely graded layers such as this in pyroclastic flows as being characteristic of the transition from turbulent to laminar flow. He points out that it is not known whether these layers represent individual surges or pulses of the flow or the development of differentially flowing lamellae within a single flow. Capping this upper part of the flow is a very fine grained dense silicified greygreen tuff which is variable in thickness averaging $1 / 2$ m. This upper part of Tcte is extremely similar in character to many of the clark Canyon tuffs, and it is interpreted to be the ash-fall constituent of the eruption. Pumice and carbon fragments are sporadically present throughout the unit. What makes Tcte such a lithologically 
unique tuff is the abundant presence of $1-2 \mathrm{~mm}$ euhedral pink K-feldspar. These pink feldspars are absent in the underlying sandstone, but are a major component of the overlying coarse grained arkose.

Tcte reappears down dip to the west at the head of Clark Canyon in sec. 9 and 10 .

In the exposure of the tuff of Eagle Creek in the road cut along North Dryden Road in the SE $1 / 4$ of the NW $1 / 4$ of the NW $1 / 4$ of sec. 36 T.24N., R. $18 \mathrm{E}$, the tuff is darker and abundant crystals of biotite and muscovite are present indicating reworking of the unit. Where Tcte crops out in the northern half of sec. 1, T.23N., R.18E., the tuff is quite sandy.

\section{CLARK CANYON TUFFS}

Excluding the tuff of Eagle Creek which is exposed at the head of the Canyon, nine tuff beds are found in this section (Plate 1, Figures 31-33). Clark Canyon nine (Tctc9), the oldest and eastern most of the Clark Canyon tuffs lies approximately $325 \mathrm{~m}$ stratigraphically above Tcte, and $1,233 \mathrm{~m}$ from tuff Tctcl, the youngest and western most tuff bed in the Clark Canyon section.

Tuff Tctc9 is a dense vitric greenish-grey tuff. It outcrops just north of sec. 9 in clark Canyon. The tuff is 30 to $45 \mathrm{~cm}$ thick and is alternatly banded in 
pale-green and dark greyish-green. The bands are $2 \mathrm{~mm}$ thick. The tuff is overlain by 1 to $1.5 \mathrm{~m}$ of tuffaceous arkose which is capped by $30 \mathrm{~cm}$ of siltstone. The tuff overlies a 5 to $8 \mathrm{~cm}$ organic rich siltstone which caps a coarse grained arkose.

Tuff Tctc8 is a fine grained dense olive-green vitric tuff at its base, and it becomes progressively more sandy toward it's top where it takes on a whitish color. The tuff is 2 to $2.5 \mathrm{~m}$ thick, and it overlies a 2 to 4 cm thick finely laminated siltstone which inturn caps a conglomeratic sandstone. Tctc 8 is overlain by $23 \mathrm{~cm}$ of dark sandy siltstone which is capped by a conglomeratic arkose.

The seventh tuff exposed in Clark Canyon (Tctc7) is found in the NE $1 / 4$ of the $\mathrm{SE} 1 / 4$ of sec. 9. There are two, thin, fine-grained olive-green vitric tuff horizons in this outcrop. The lower one is capped by less than a meter of angular clasts of tuff and pumice. The upper thin vitric tuff is capped by a two meter debris flow or ash flow (Figure 22). The diamictite has angular clasts of pumice, tuff, and a $15 \mathrm{~cm}$ diameter tree limb preserved in the fine grained ash matrix. Well preserved leaf fossils can be found along the upper vitric horizon. The sixth tuff exposed in Clark Canyon (Tctc6) is a green-grey, fine-grained, vitric tuff. An excellent exposure occurs in the NW $1 / 4$ of the SE $1 / 4$ of sec. 9 


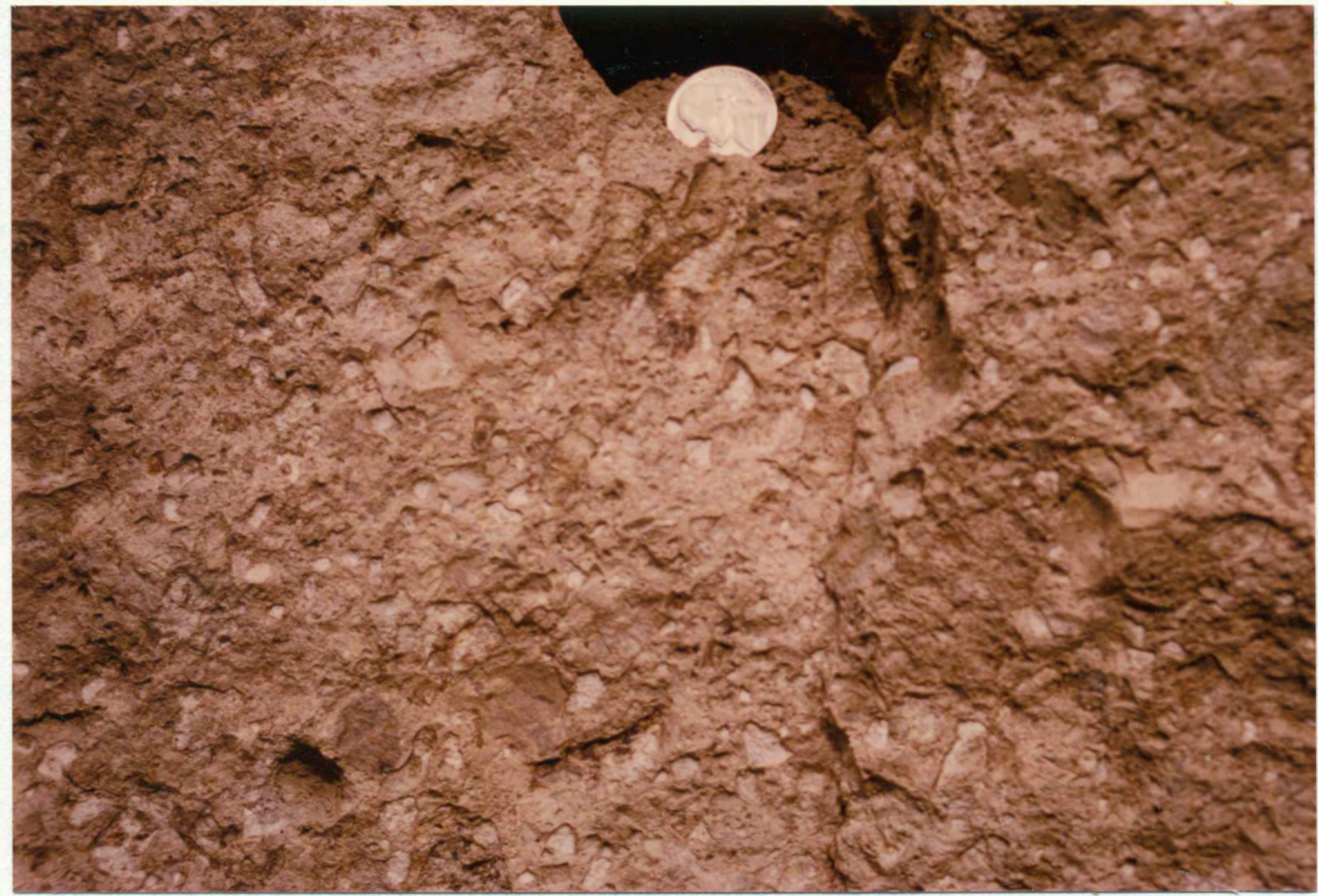

Figure 22. Diamictite portion of the tuff of Clark Canyon seven (Tctc7). 
along Clark Canyon Road. The Tuff is $3.2 \mathrm{~m}$ thick here and is carbon rich at its base. It has a sharp lower contact with arkosic sandstone. Laminar bedding is present in the upper portion, and the tuff becomes rich in sand in a narrow $30 \mathrm{~cm}$ interval toward its top.

Tuff Tctc5, is a pale grey-green vitric tuff which outcrops in the SW $1 / 4$ of the NW $1 / 4$ of sec. 9 . The tuff is $60 \mathrm{~cm}$ thick and increases in detrital content toward its top until grading into a tuffaceous sandstone. Carbon fragments are present, and a thin pumiceous zone occurs at the southern exposure (sample location 33, Figure 31). Tuff Tctc4, is a dense bluish-grey pumiceous vitric tuff. It is separated from Tctc5 by 321 statigraphic meters. The tuff can be traced sporadically for 10.5 $\mathrm{km}$, and it is one of the more unique marker beds in the Clark Canyon sequence both in hand sample and in thin section. If the correlation suggested in this study is correct, the tuff bed can be traced intermittently for $41 \mathrm{~km}$. The texture in thin section shows the tuff to be moderately welded (Figure 23).

Pumice sporadically occurs throughout the tuff. There is no evidence of reworking or increase in detrital content until the top few centimeters of the tuff. The bottom and top contacts are sharp. Carbon fragments are scattered within the tuff. Rare, glossy black fine grained lithic fragments less than $1 \mathrm{~cm}$ occur in all three 


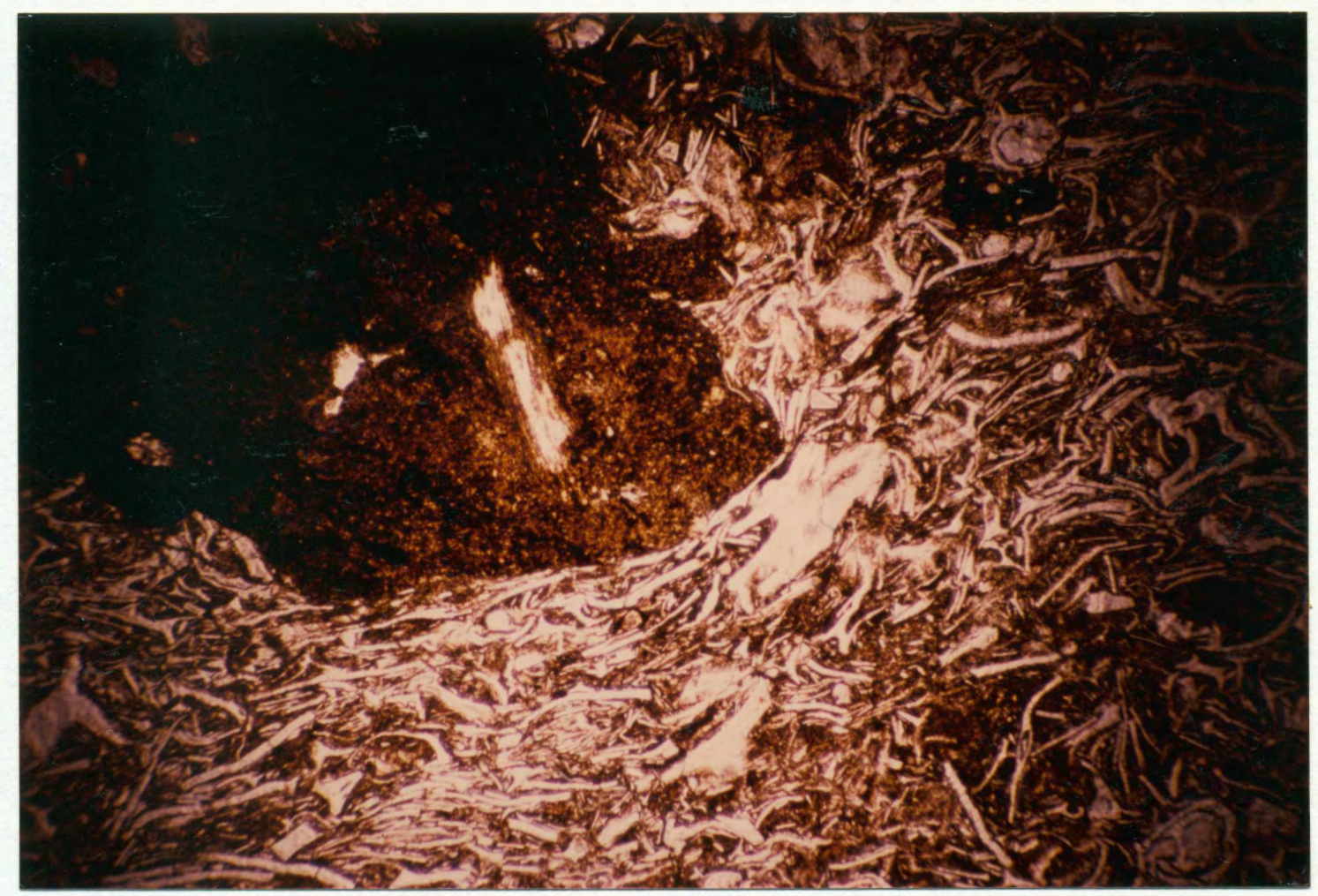

Figure 23. Photomicorgraph of the tuff of Clark Clark Canyon four (Tctc4) showing the welding of glass shards around a lithic fragment. 
exposures. A thin section shows these lithic fragments to be a fine grained volcanic.

The tuff is $3 \mathrm{~m}$ thick at its exposures in sec. 8 and 9 in Clark Canyon and at its exposure in the SE $1 / 4$ of sec. 4, T.24N., R. 18E., in Derby Canyon. Its thickness was not discernable at its southern exposure in the center of sec. 10, T.23N., R.18E. Pumice is much larger and more abundant at this southern exposure.

The third tuff of Clark Canyon (Tctc3) is a greyishgreen vitric tuff. There are two excellent and accessible exposures of the tuff. The northernmost of which occurs in the NE $1 / 4$ of sec. 31, T. $26 \mathrm{~N} ., \mathrm{R} .18 \mathrm{E}$. The exposure is along the road cut of Hwy. 209. The tuff is approximately $4.25 \mathrm{~m}$ thick here. Pumice clasts $1.5 \mathrm{~cm}$ in diameter are found along the basal $10 \mathrm{~cm}$ of the tuff. Detrital content increases toward the top of the unit.

The southern exposure of Tctc 3 , along Walker Canyon Road in the SE $1 / 4$ of the SE $1 / 4$ of sec. 8 , is only 1.5 $m$ thick. The tuff coarsens upwards with the addition of detritus. Shallow trough cross-bedding is present toward the top, and stilbite veneers several fractures.

Tuff Tctc2, is commonly a ridge former and is a major marker bed within the Chumstick Formation. The tuff can be traced from its northern most exposure in the SE $1 / 4$ of sec. $30, T .26 \mathrm{~N} ., R_{0} 18 \mathrm{E}$., for approximately $15.3 \mathrm{~km}$ south where it strikes below the alluvium of the 
Wenatchee River at the Peshastin Cemetery.

The tuff consists of two parts. The basal zone is an olive-green, very fine-gained, dense-silicified tuff. Its base is characterized by a planar lamination. Above the base, the tuff is more coarse as detrital sand is mixed with the ash. Lenses of pumice averaging about 6 to $8 \mathrm{~cm}$ thick are present in the coarser part of this zone (Figure 24). The second part is a white tuffaceous, pebbly sandstone which overlies part one. The suspension of pebbles in a matrix of fine-grained tuff suggests that the capping layer was a thin mudflow.

An excellent exposure along Walker Canyon Road at the eastern border between sec. 8 and 17 provides a crosssection of the tuff. Here the fine-grained base overlies a thin bed of carbon rich siltstone. An average diameter for the ten largest pumice is $0.97 \mathrm{~cm}$ with the largest being $1.3 \mathrm{~cm}$ in diameter.

Lenses of pumice and the increase in detrital content toward the top of the unit argues that the tuff was water-laid, and in places it is reworked into a tuffaceous sandstone. The outcrop of Tctc2 along the Eagle Creek Road in the NW $1 / 4$ of sec. $28, T 25 N$, R18E, shows an example of this reworking well. Here the pink zeolite stilbite pervasively veneers fracture faces.

The upper tuff bed, Tctcl, is an olive green vitric tuff. It crops out poorly in road cuts along walker can- 


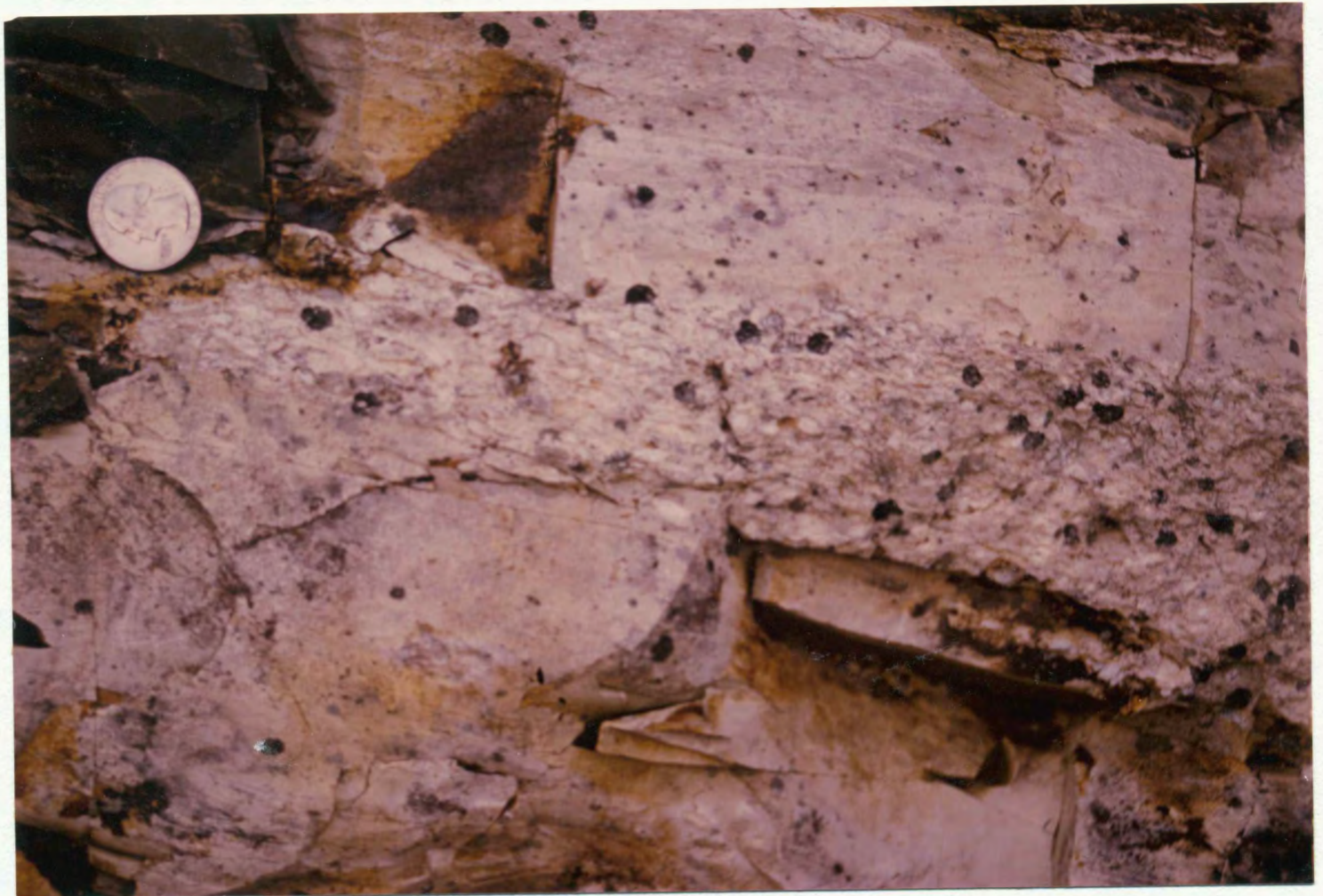

Figure 24. Lense of pumice clasts present in the tuff of Clark Canyon two. 
yon Road in the NE $1 / 4$ of section 17, T.25N., R. 18E. Here it is about one meter thick, and fracture surfaces are stained by manganese dioxide.

\section{TUFFS OF SUNITSCH CANYON}

A pair of tuffs occur in Sunitsh Canyon (Plate 1 , Figure 31). The upper tuff, Tctsl, outlines a north plunging syncline. Both of the tuff beds are significantly reworked by fluvial processes, and consequently further laboratory study was not pursued. However, their lithology contrasts enough with the arkose that they both make excellent field marker beds so a brief description is given here.

The lower unit, Tcts 2 , is a three-meter thick ridgeforming bed of flaggy tuffaceous sandstone.

The upper tuff bed, Tctsl, is approximately $9 \mathrm{~m}$ thick were it crosses the ridge in the $S E 1 / 4$ of sec. 12, T.25N., R.18E. It overlies a medium-grained arkose. The lower half of the tuff is a tuffaceous clast-rich sandstone. The upper one-half is a generally clast-supported tuffaceous conglomerate. The tuff component is a white clay matrix. Many clasts appear to consist of a flow-banded rhyolite, other clasts include volcanic porphery and gneiss up to $20 \mathrm{~cm}$ in diameter. 
TUFFS OF UNCERTAIN STRATIGRAPHIC POSITION

TUFF OF EAST MISSION CREEK

Tabor and others (1982) correlate a tuff in the upper east Eork of Mission Creek, Tctem, (Figures 25 and 35) with the tuff of Eagle Creek (Tcte) on the bases of their similar lithology. The tuff of Eagle Creek has been mapped as far south as Trip Canyon (Tabor and others, 1982). However, chemical data presented in this study indicates that Tctem and Tcte are different and that Tctem is very chemically similar to the tuff of Clark Canyon four $(\operatorname{Tctc} 4)$.

The tuff in Mission Creek outcrops on both 1 imbs of a tight syncline. The tuff here is a black dense pumiceous vitric tuff. Obsidian is present in $1-3 \mathrm{~mm}$ patches. The most accessible and best outcrop is on the east limb of the syncline in the NW $1 / 4$ of the NW $1 / 4$ of the SW $1 / 4$ of sec. 2, T. $21 N .$, R. 19E. Here the tuff occurs in dip slope. With corrections for slope the unit is $6 \mathrm{~m}$ thick. Carbon and wood fragments are present.

The exposure on the west side of the syncline is excellent. Here the tuff dips vertically and is also $6 \mathrm{~m}$ thick. There is no 1 ithological variation between the exposures on both limbs of the syncline. 


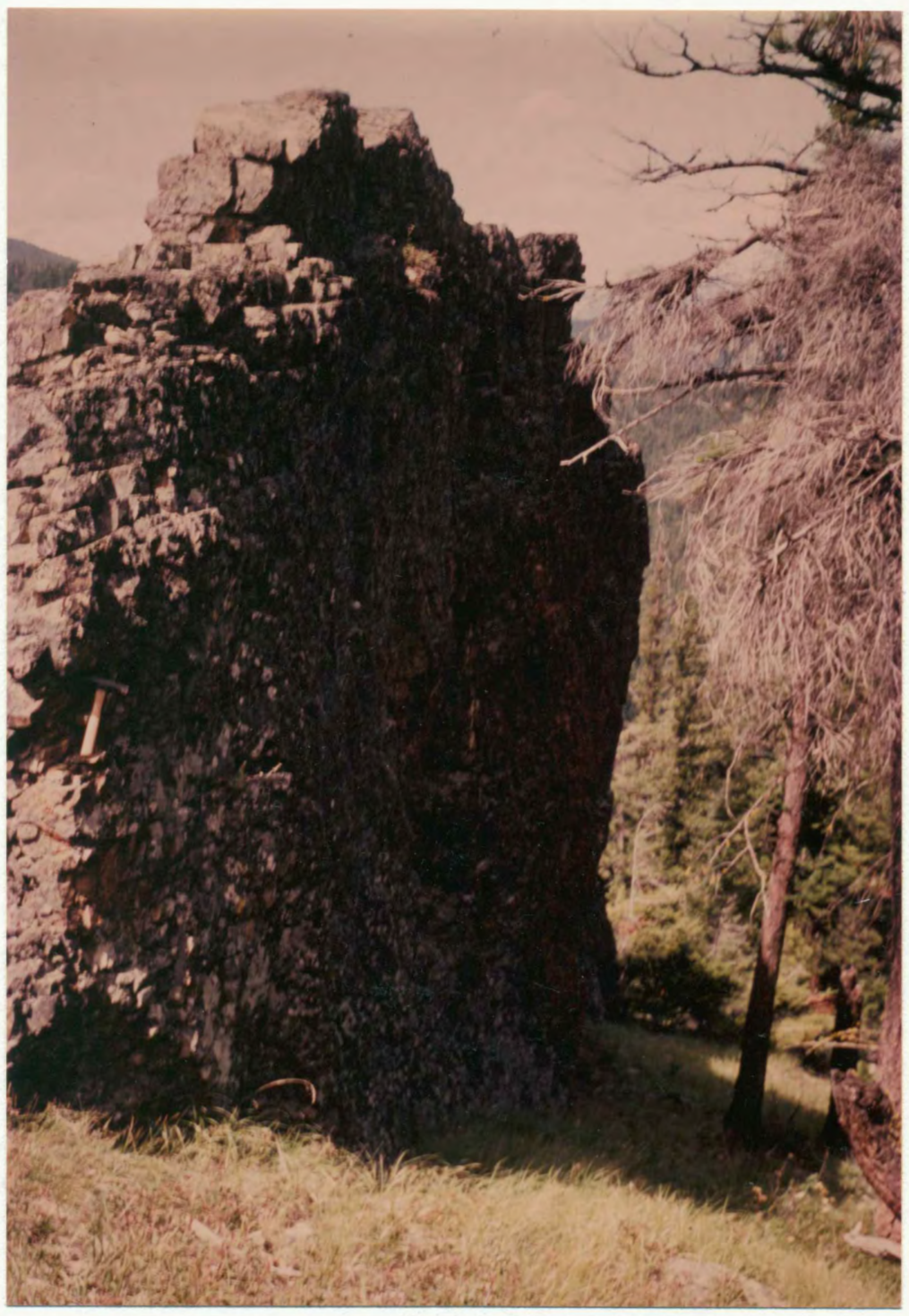

Figure 25. Tuff of East Mission Creek, dipping vertically and differentially weathering from the enclosing arkose. 
HORSE LAKE MOUNTAIN TUFFS

Gresens, (1983) mapped and described in detail three isolated exposures of tuffs in sections 3,10 , and 14 , T. $22 \mathrm{~N} .$, R.19E., in the Horse Lake Mountain area (Figure 35). The structural complexity of the area does not easily allow for projections from one exposure to another or to the tuffs of Yaxon Canyon.

\section{TUFFS OF DERBY CANYON}

Two tuffs are found in Derby Canyon (Figure 32 ). A detritus rich 2 m thick, greenish-grey tuff (Tctdl) is found in the NE $1 / 4$ of the SE $1 / 4$ of sec. 10 T. $24 \mathrm{~N}$., R.18E, in a road cut on the east side of Derby Canyon Road. The second tuff (Tctd2) is also of a detritus rich tuff. It is exposed just below the center of sec. 34, T.25N., R.18E.,along the North Fork Derby Canyon Road. Both tuffs are too contaminated with detritus for chemistry, but they are along strike with the clark Canyon section and should correlate with tuffs in clark Canyon to the north. 
UNNAMED TUFF BEDS

Chemical data was obtained on a tuff exposed in the NW $1 / 4$ of the NW $1 / 4$ of sec. 27, T.25N., R.18E., along the Eagle Creek Road (Figure 32 ). This tuff overlies a sandy siltstone and is overlain by a tuffaceous sandstone $60 \mathrm{~cm}$. thick. The tuff is stratigraphically west of the tuff of Eagle Creek and should correlate with a tuff in clark Canyon. The tuff is not as cherty as most of the Chumstick tuffs; it contains a higher percentage of clay. Its thickness and lithology make it similar to $\operatorname{Tctc} 5$.

Abundant float from a tuff of unknown correlation is found along a road cut on the east flank of the Eagle Creek anticline in the SE $1 / 4$ of the NE $1 / 4$ of sec. 23 , T.25N., R.18E. The tuff is stratigraphically younger than the tuff of Eagle creek and again should correlate with one of the Clark Canyon tuffs. Even though the unit is detrital rich it was analyzed for chemistry. It was subsequently noticed that the sample locality is within a large landslide block mapped by Tabor and others (1980). Since the exact stratigraphic position is now uncertain for this sample, it is ignored. However, its tenative correlation is mentioned in the discriminant anlysis, and it was included in the cluster analysis dendrogram. 
LOCATION MAP FOR FIGURES $27-35$

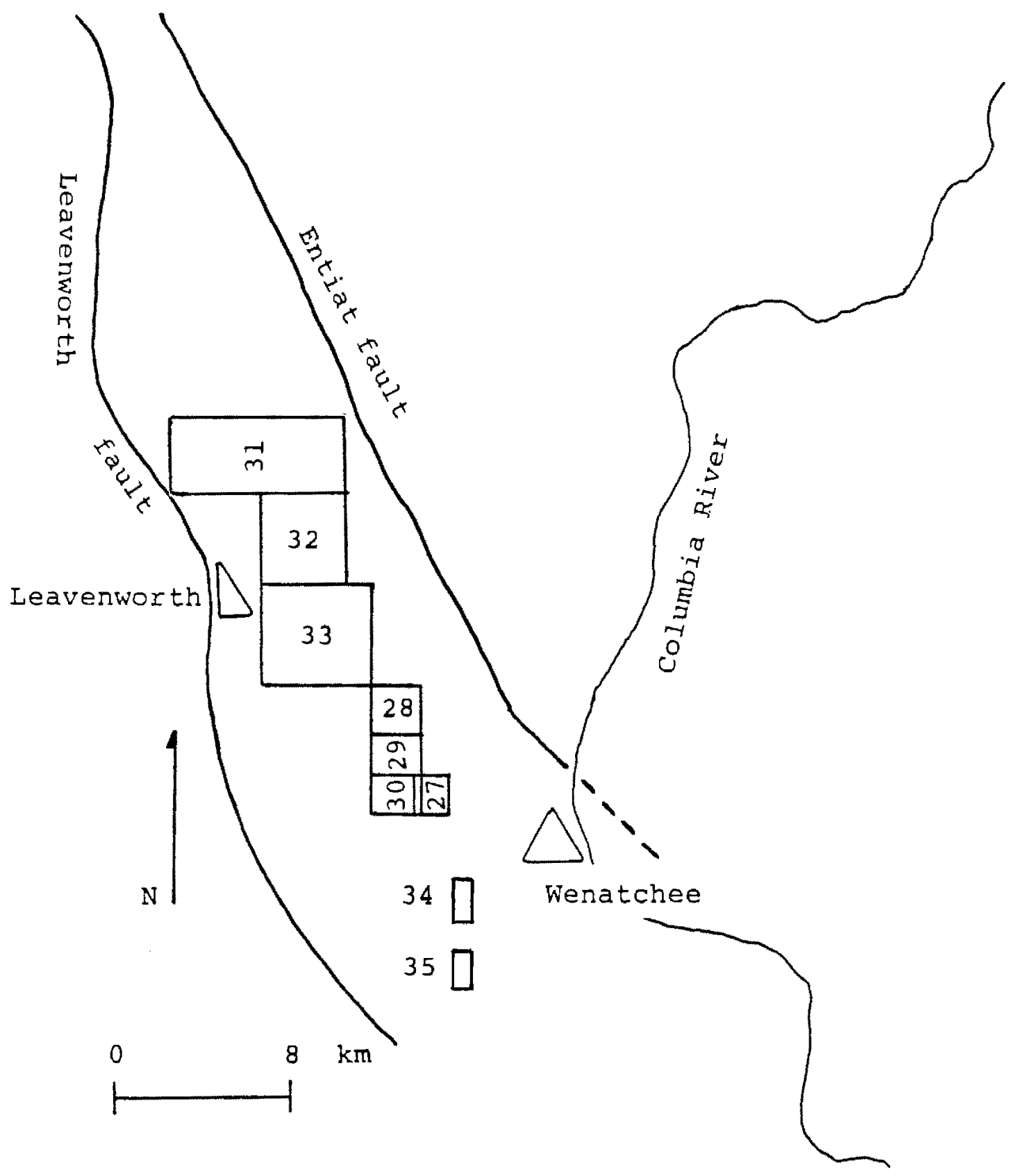

Figure 26. Location map for Figures $27-35$. 
EXPLANATION

F IGURES 27-35

Tct

Tertiary Chumstick Tuff

46

Sample location number corresponds to sample numbers in Tables $\mathrm{V}-\mathrm{IX}$

Figures 31-33 Geology compiled from Tabor and Others, 1980 Figure 28 Geology compiled from Tabor and Others, 1980 Figures 27, 29, 30 and 35 Geology from Gresens, 1983

Figure 34 Geology from Tabor and Others, 1982 


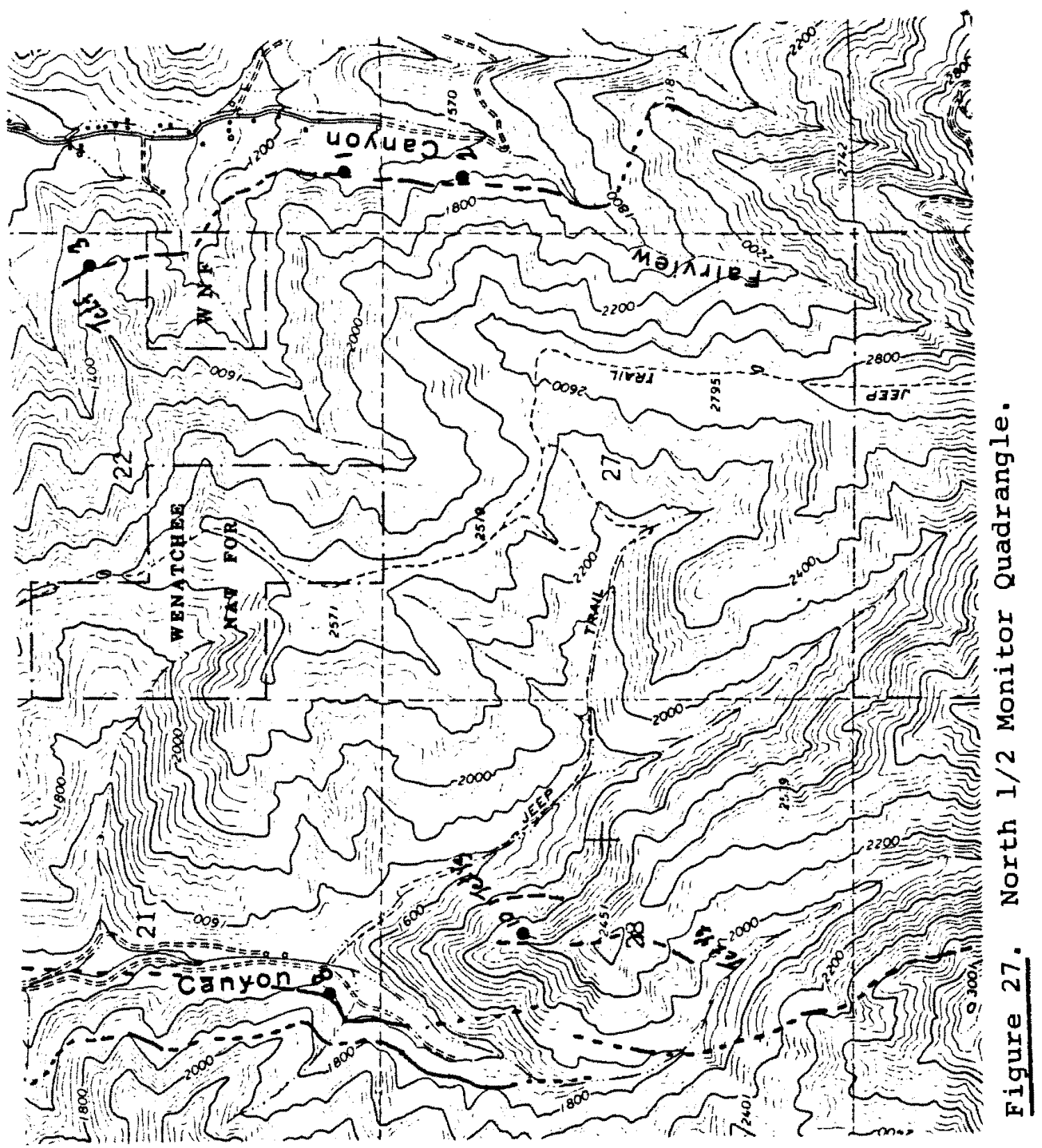




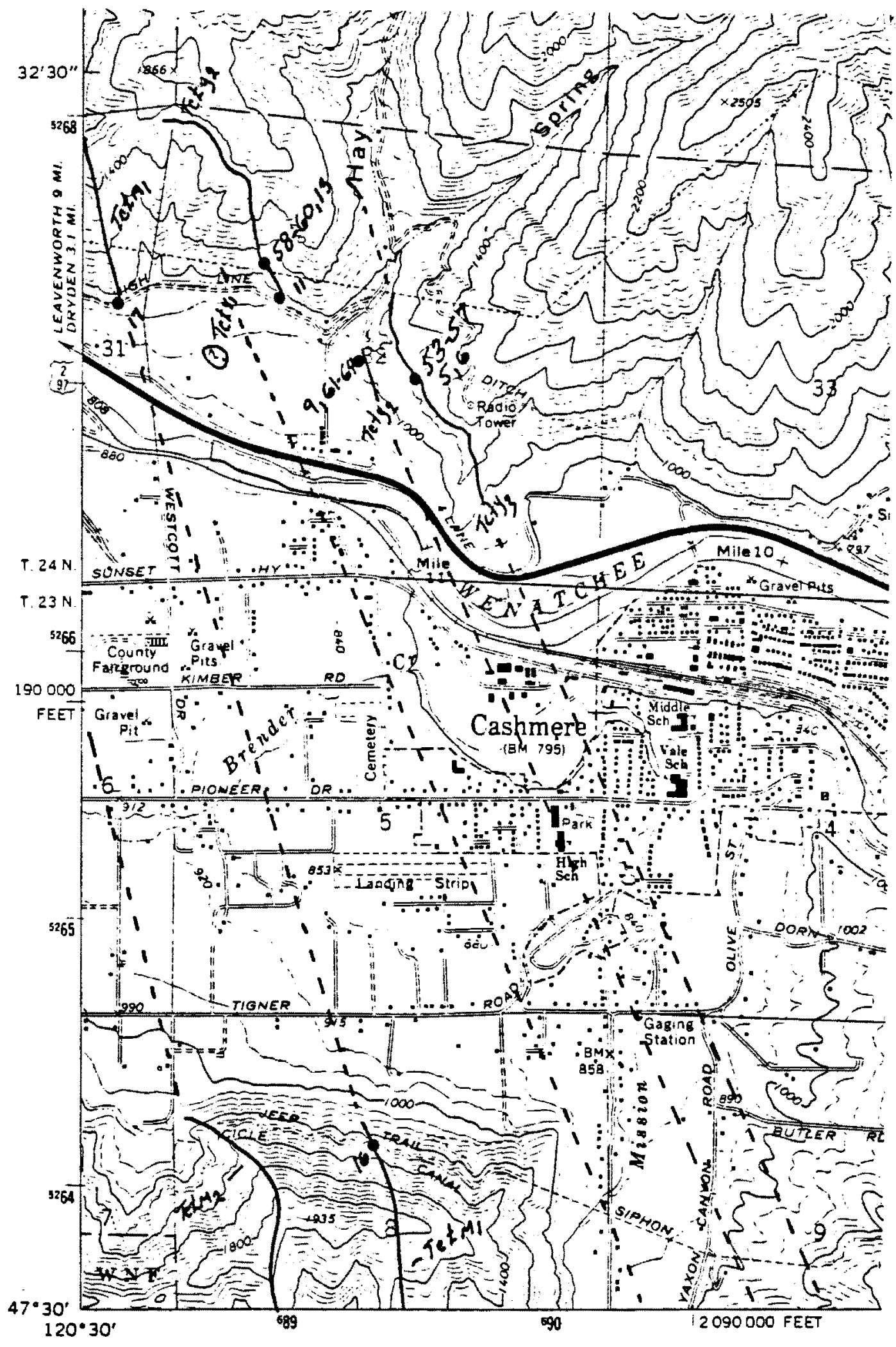

Figure 28. SW 1/4 Cashmere Quadrangle. 


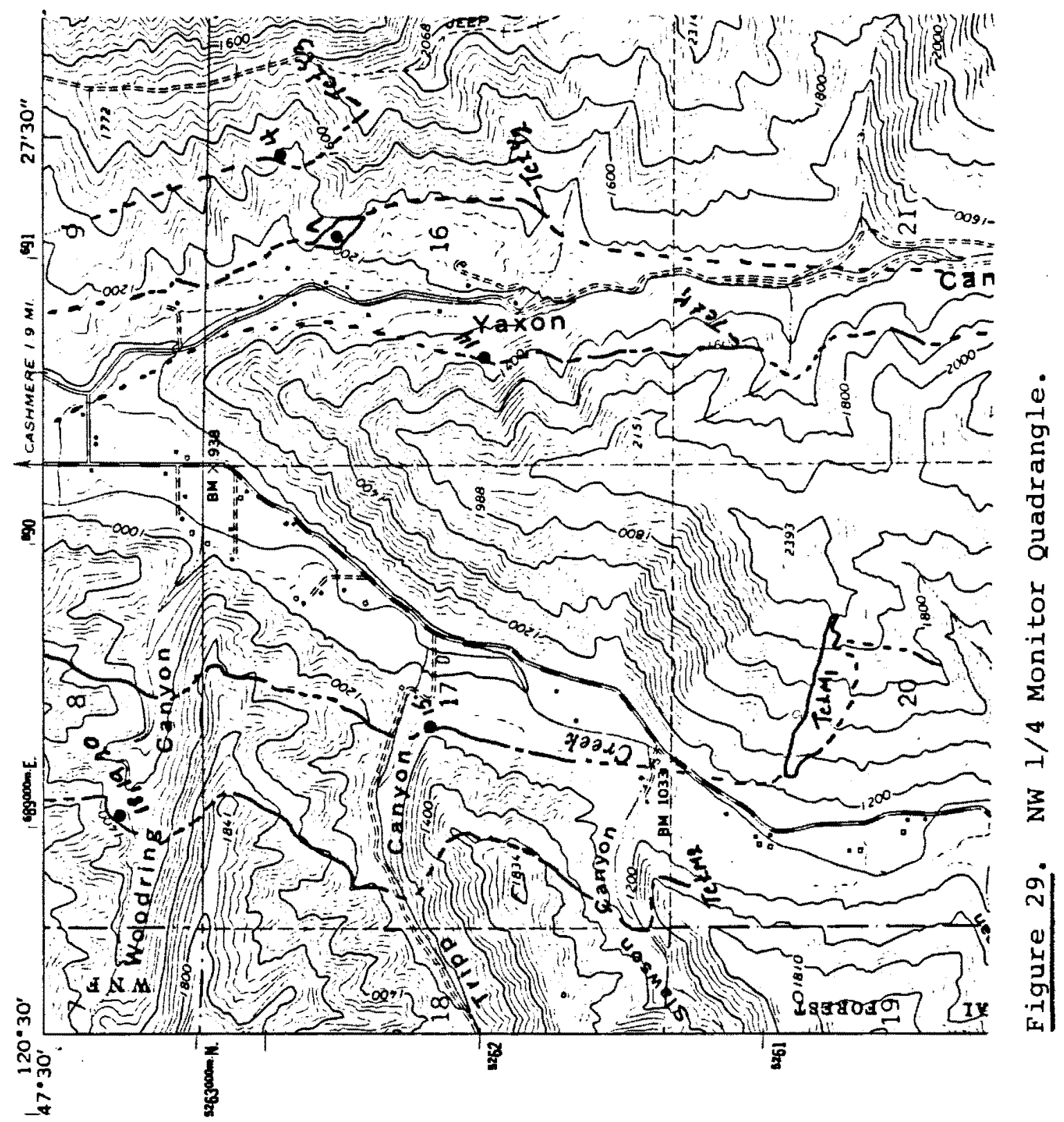




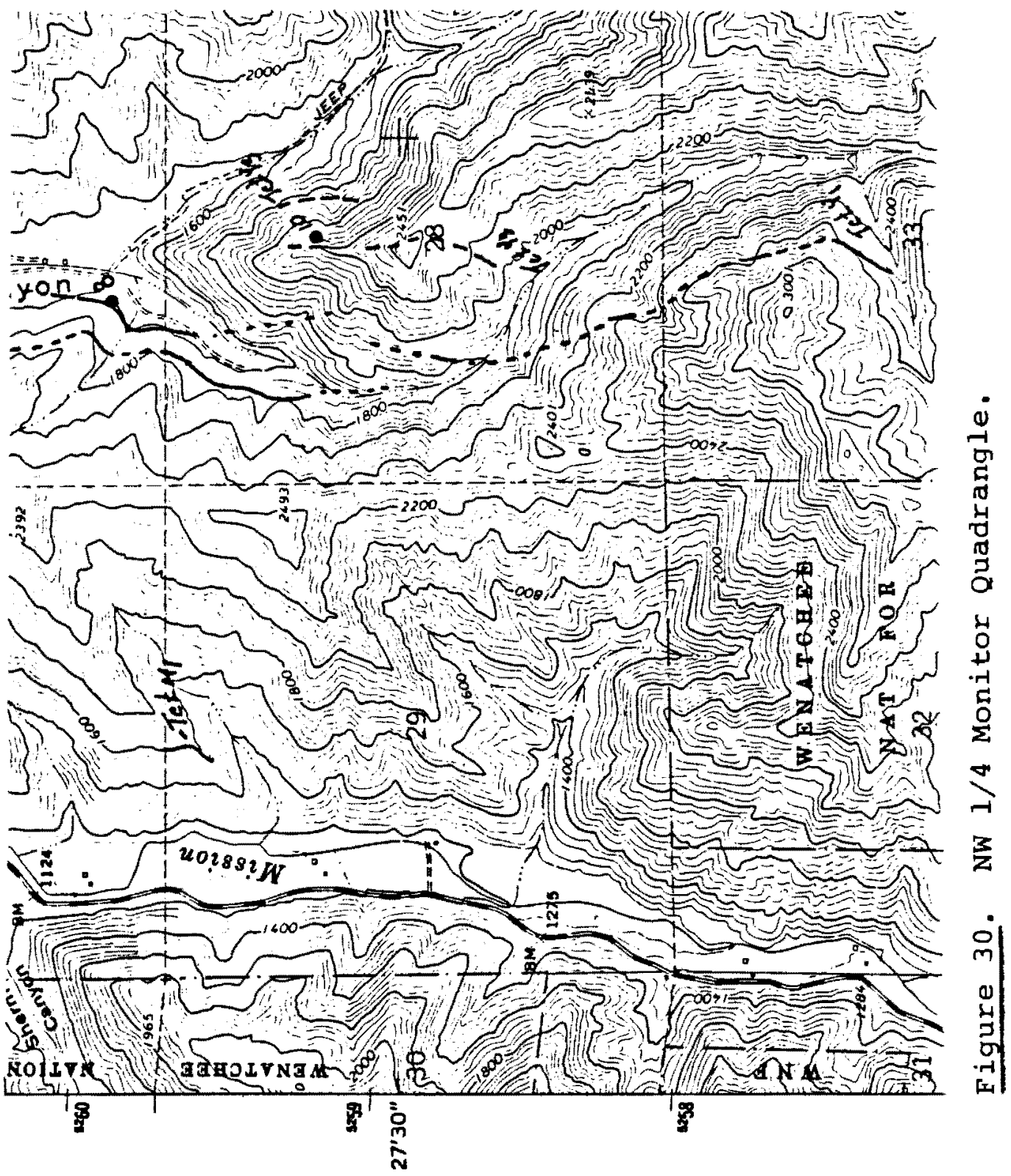




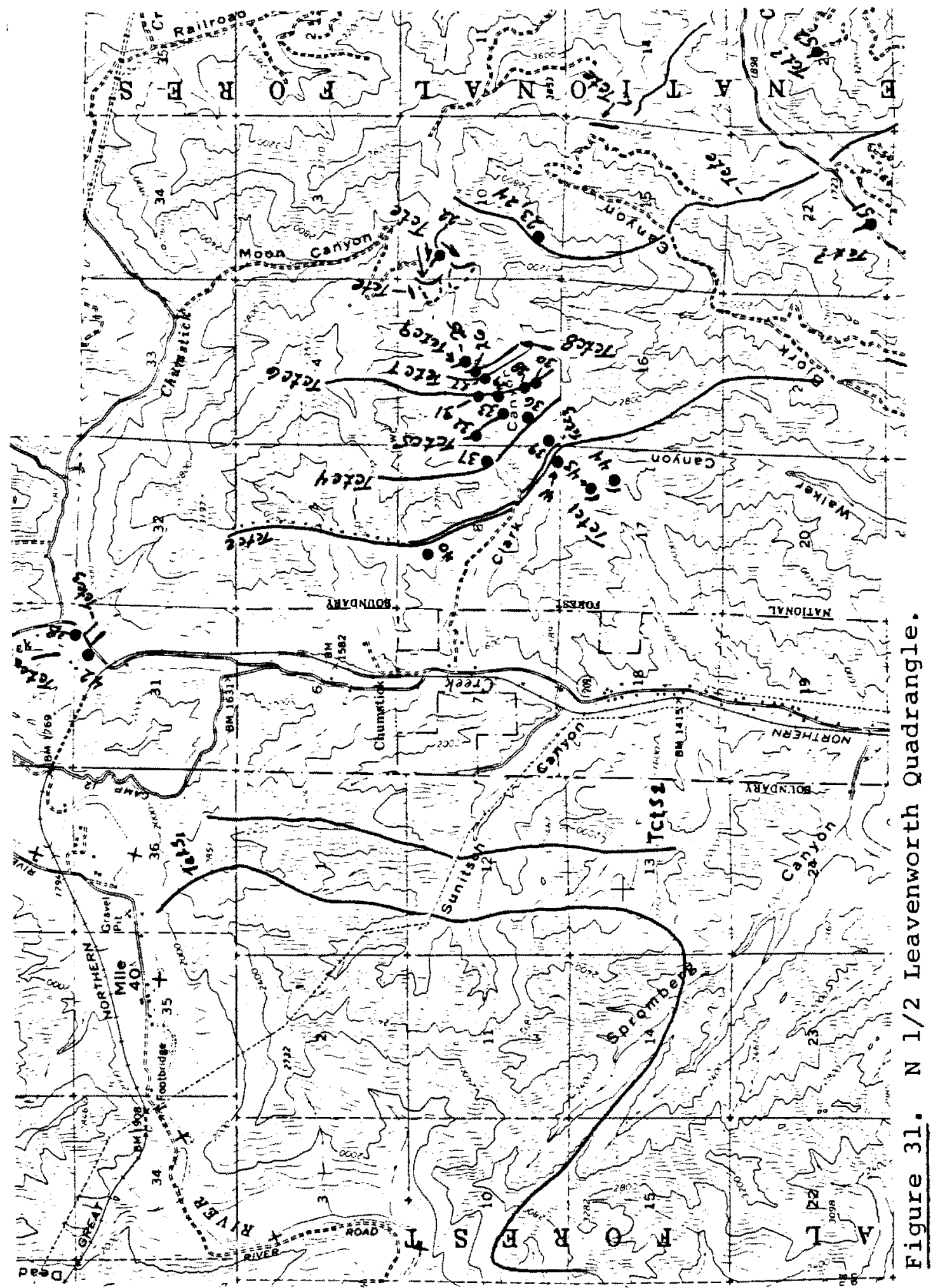




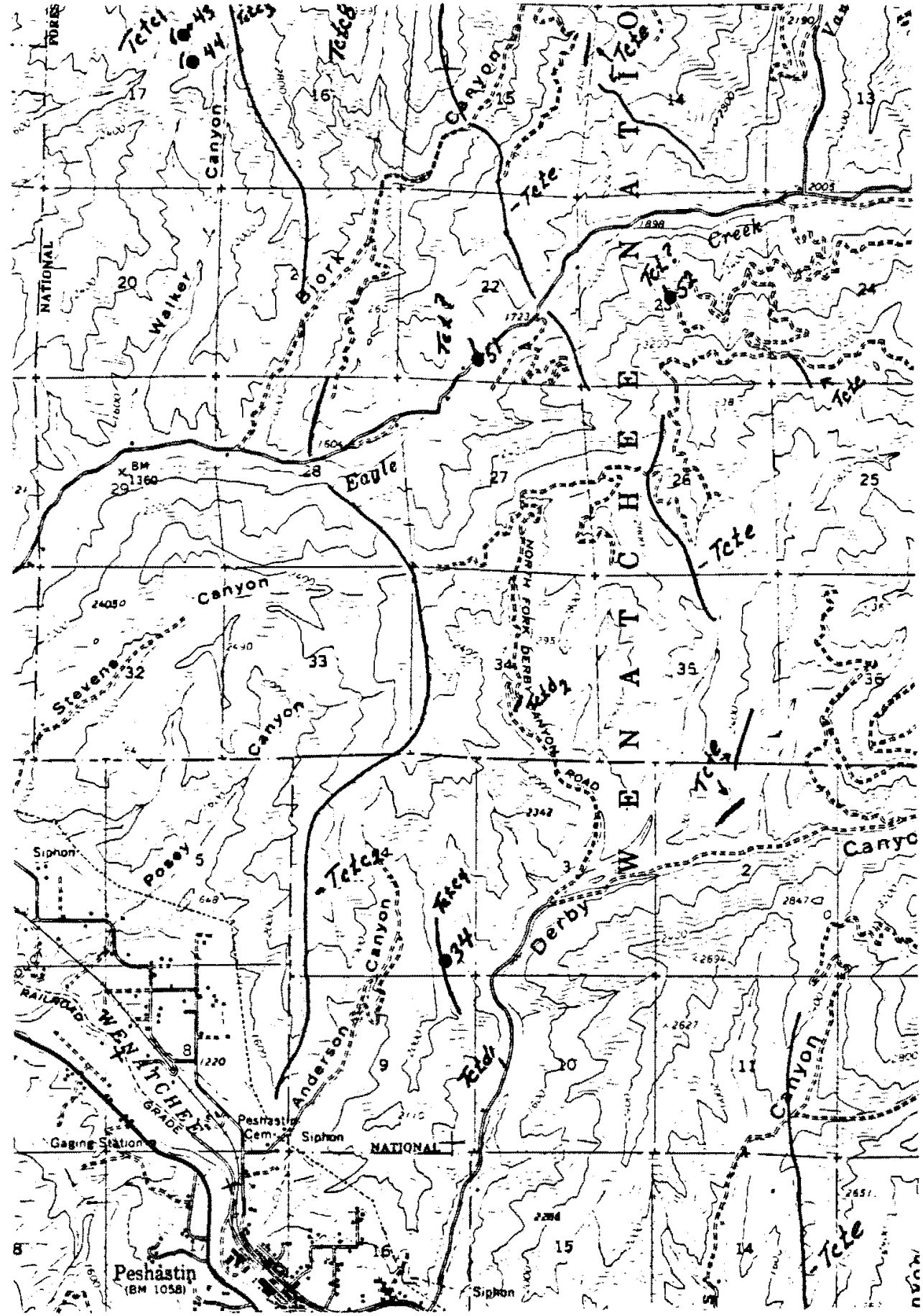

Figure 32. E 1/2 Leavenworth Quadrangle. 


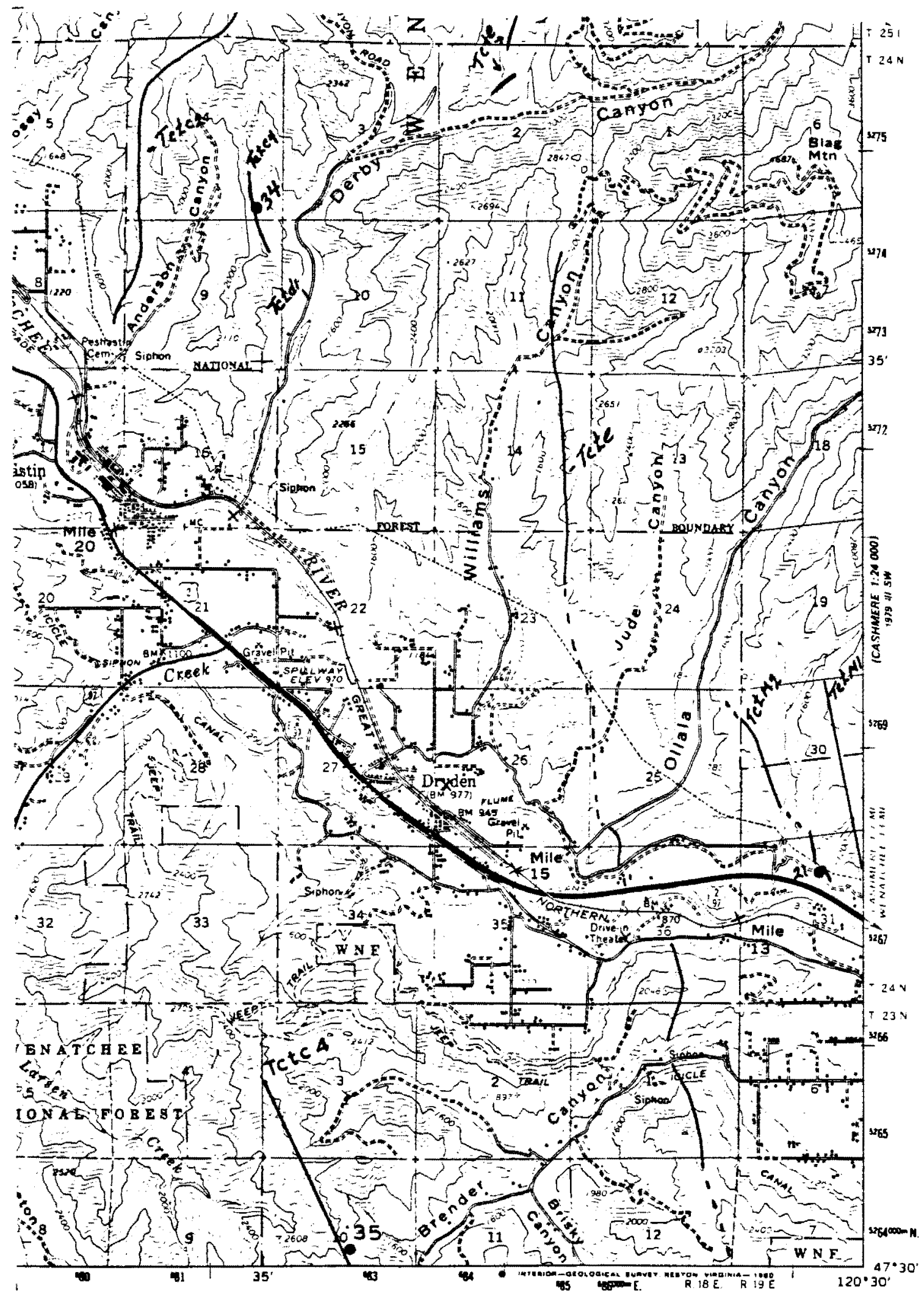

Figure 33. SE 1/4 Leavenworth Quadrangle. 


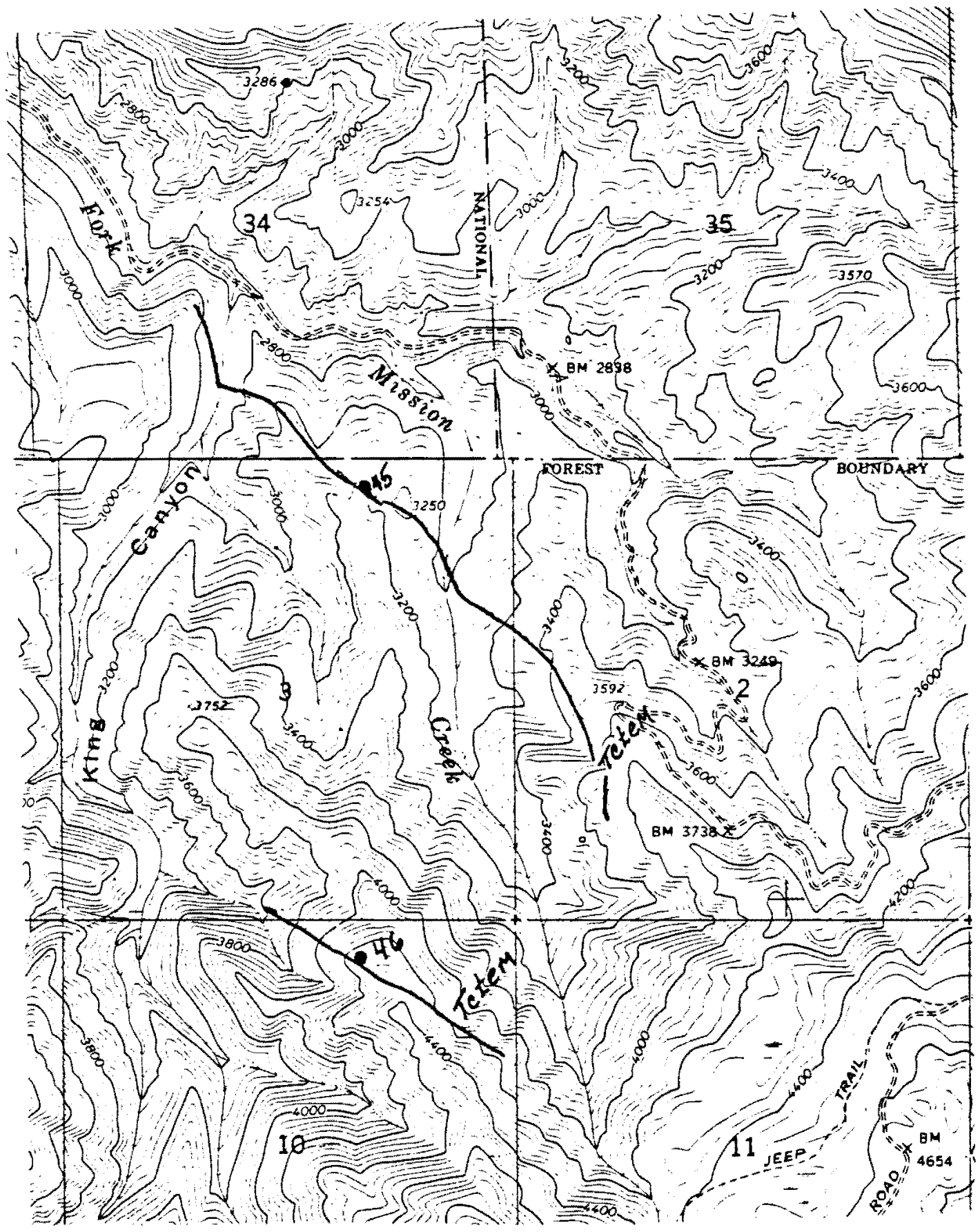

Figure 34. N 1/2 Mission Creek Quadrangle. 


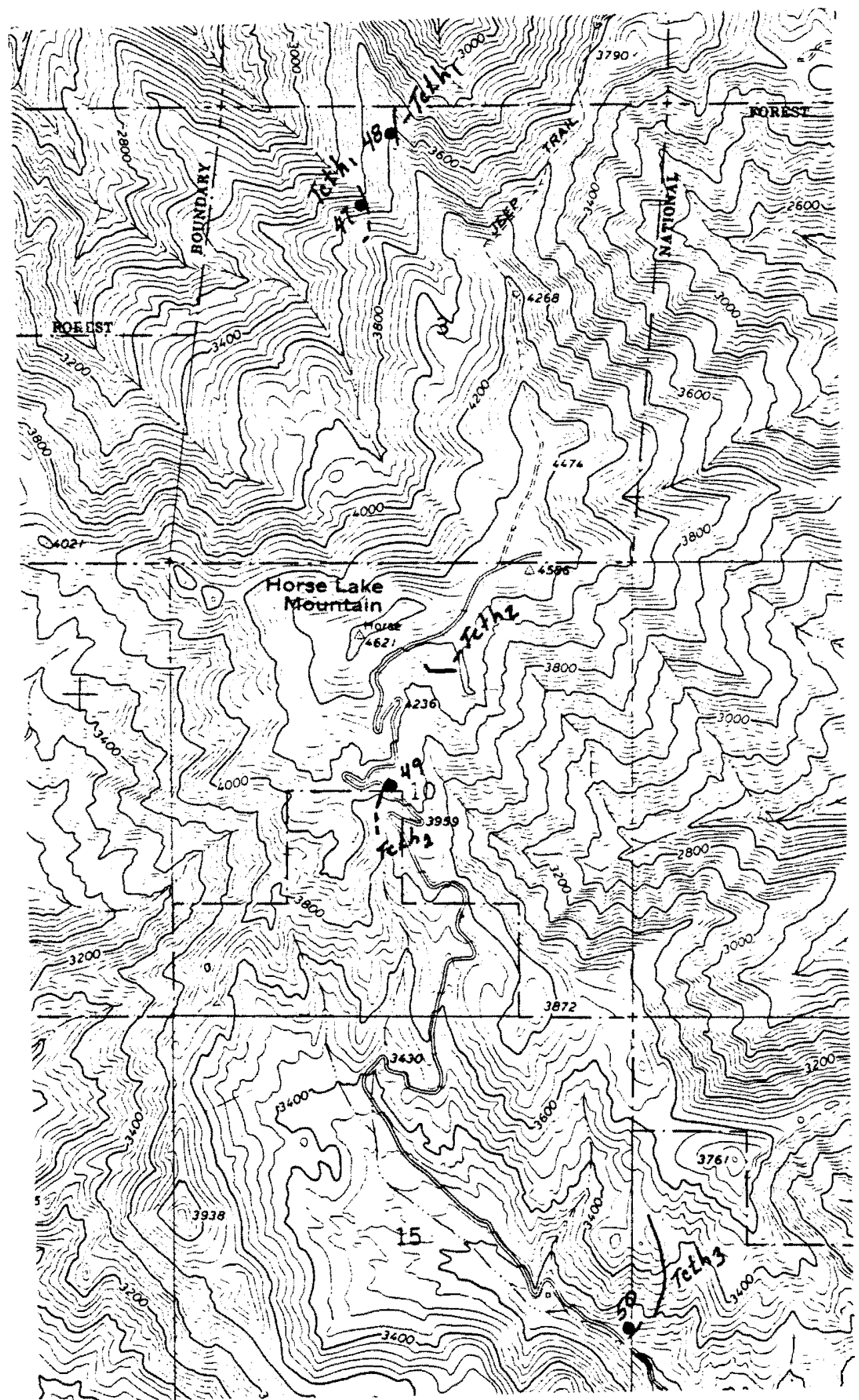

Figure 35. S 1/2 Monitor Quadrangle. 


\title{
APPENDIX F
}

\author{
TABLE $\mathbf{V}$
}

LOCATION OF CHEMICAL SAMPLES

\begin{tabular}{|c|c|c|c|c|c|c|}
\hline SPL & UNIT & LOCATION & & & & COMMENT \\
\hline 1 & Tctf & SW1/4, SW1/4 & SEC.23 & T23N & R19E & FAIRVIEW CANYON \\
\hline 2 & Tctf & $\mathrm{NW1} / 4, \mathrm{NW1} / 4$ & SEC. 26 & T23N & R19E & FAIRVIEW CANYON \\
\hline 3 & Tctf & SEl/4 & SEC. 22 & T23N & R19E & ALTERED \\
\hline 4 & Tety 3 & $\mathrm{NW1} / 4, \mathrm{NE1} / 4$ & SEC.16 & $\mathrm{T} 23 \mathrm{~N}$ & R19E & YAXON CANYON \\
\hline 5 & Tety 3 & NW1 14 & SEC. 32 & T24N & R19E & EAST OF HAY CANYON \\
\hline 6 & Tcty 3 & NWI $/ 4$ & $\mathbf{S}$ & $4 \mathbf{N}$ & R19E & EAST OF HAY CANYON \\
\hline 7 & Tcty 2 & N. OF CEN. & SEC.16 & T23N & R19E & DIP SLOPE YAX. CAN. \\
\hline 8 & Tcty 2 & SE1/4 & & T23N & R19E & YAXON CANYON \\
\hline 9 & Tcty 2 & $\operatorname{NE1} 1 / 4$ & SEC. 32 & T24N & R19E & HAY CANYON \\
\hline 10 & Tcty 2 & NW1/4 & SEC. 28 & T23N & R19E & HEAD OF YAXON CAN. \\
\hline 11 & $\operatorname{Tcty} 2$ & $\operatorname{SWl} / 4$ & & T24N & R19E & WEST OF HAY CANYON \\
\hline 12 & Tety 2 & $\operatorname{NEl} / 4$ & & T24N & R19E & HAY CANYON \\
\hline 13 & Tcty 2 & $\mathrm{SH1} / 4$ & & T24N & R19E & WEST OF HAY CANYON \\
\hline 14 & TetyI & NW1/4 & SEC.16 & $\mathrm{T} 23 \mathrm{~N}$ & R19E & YAXON CANYON \\
\hline 15 & TctmI & $\mathrm{SE1} / 4, \mathrm{NE1} / 4$ & SEC. 17 & $\mathrm{~T} 23 \mathrm{~N}$ & R19E & TRIPP CANYON \\
\hline 16 & Tctml & $\mathrm{SE1} / 4, \mathrm{NW1} / 4$ & SEC. 8 & $\mathrm{~T} 23 \mathrm{~N}$ & R19E & IRRIGATION CANAL \\
\hline 17 & $\operatorname{Tctm} 1$ & SE1/4 & SEC. 31 & T24N & R19E & N. HEN. RIVER \\
\hline 18 & $\operatorname{Tctm} 2$ & NE1/4 & SEC. & T23N & R19E & WOODRING CANYON \\
\hline 19 & $\operatorname{ctm} 2$ & NE1/4 & SEC. & T23N & R19E & WOODRING CANYON \\
\hline 20 & Tctm2 & NE1/4 & SEC. & T23N & R19E & WOODRING CANYON \\
\hline 21 & Tctan 2 & $\mathrm{NW1} / 4$ & SEC. 31 & T24N & R19E & N. WEN. RIVER \\
\hline 22 & $\overline{\text { Tcte }}$ & NW1/4 & SEC. 10 & T25N & R18E & WALRER CANYON RD. \\
\hline 23 & cte & $S W 1 / 4$ & 10 & & R18E & BJORR CANYON \\
\hline 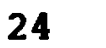 & te & SW1/4 & & $\mathbf{T}$ & R18E & BJORK CANYON \\
\hline 25 & Tctc 9 & SE1/4,NW1/4 & SEC. 9 & T25N & R18E & CLARK CANYON RD. \\
\hline 26 & Tctc 8 & $\mathrm{SEl} / 4, \mathrm{NW1} / 4$ & SEC. 9 & $\mathrm{~T} 25 \mathrm{~N}$ & R18E & CLARK CANYON RD. \\
\hline 27 & Tetc7 & NE1 $/ 4,5 W 1 / 4$ & SEC. & T25N & R18E & CLARR CANYON RD. \\
\hline 28 & Tctc6 & NE1 $/ 4,5 W 1 / 4$ & SEC. 9 & T25N & R18E & CLARR CANYON \\
\hline 29 & Tctc 6 & $\mathrm{NE1} / 4$ & SEC. & $\mathbf{T}$ & R18E & CLARK CANYON RD. \\
\hline 30 & Tetc 6 & $\operatorname{SE1} / 4$ & SEC. & T25N & R18E & CLARR CANYON \\
\hline 31 & Tctc6 & $\mathrm{SWI} / 4, \mathrm{NN1} / 4$ & SEC. & T25N & R18E & RIDGE TOP \\
\hline 7 & Tetc5 & SW1/4,NW1/4 & SEC. & T25N & RI8E & CLARK CANYON RD. \\
\hline 3 & ctc 5 & $\mathrm{NW1} / 4, \mathrm{SWl} / 4$ & SEC. & T25N & R18E & CLARR CANYON RD. \\
\hline & tc4 & SE1 $/ 4$ & SEC. 4 & $T 24 N$ & R18E & DERBY CANYON \\
\hline 35 & c4 & NWI & SEC. 10 & T23N & R18E & BRENDER CANYON \\
\hline 0 & Tctc4 & SW1/ & SEC. & T25N & R18E & WALKER CANYON RD. \\
\hline 37 & Tetc4 & SEl/4 & SEC. 8 & T25N & R18E & CLARK CANYON RD. \\
\hline & Tctc3 & NE1/4 & SEC.31 & $\mathrm{T} 26 \mathrm{~N}$ & R18E & BWY 209 \\
\hline & Tctc3 & $\operatorname{SE1} / 4, \operatorname{SEl} / 4$ & SEC. 8 & & R18E & WALKER CANYON RD. \\
\hline & tc2 & NE1/4, NWI/4 & SEC. 8 & T25N & R18E & N. RIDGE CLARR CN. \\
\hline & & $\mathrm{NEl} / 4, \mathrm{NE1} / 4$ & SEC. 17 & & & WALRER CANYON RD. \\
\hline & & $\mathrm{NE1} / 4, \mathrm{NE}$ &. .31 & & R18E & HWY. 209 \\
\hline & & & & & & \\
\hline
\end{tabular}


TABLE V

LOCATION OF CHEMICAL SAMPLES

SPL UNIT LOCATION COMHENT

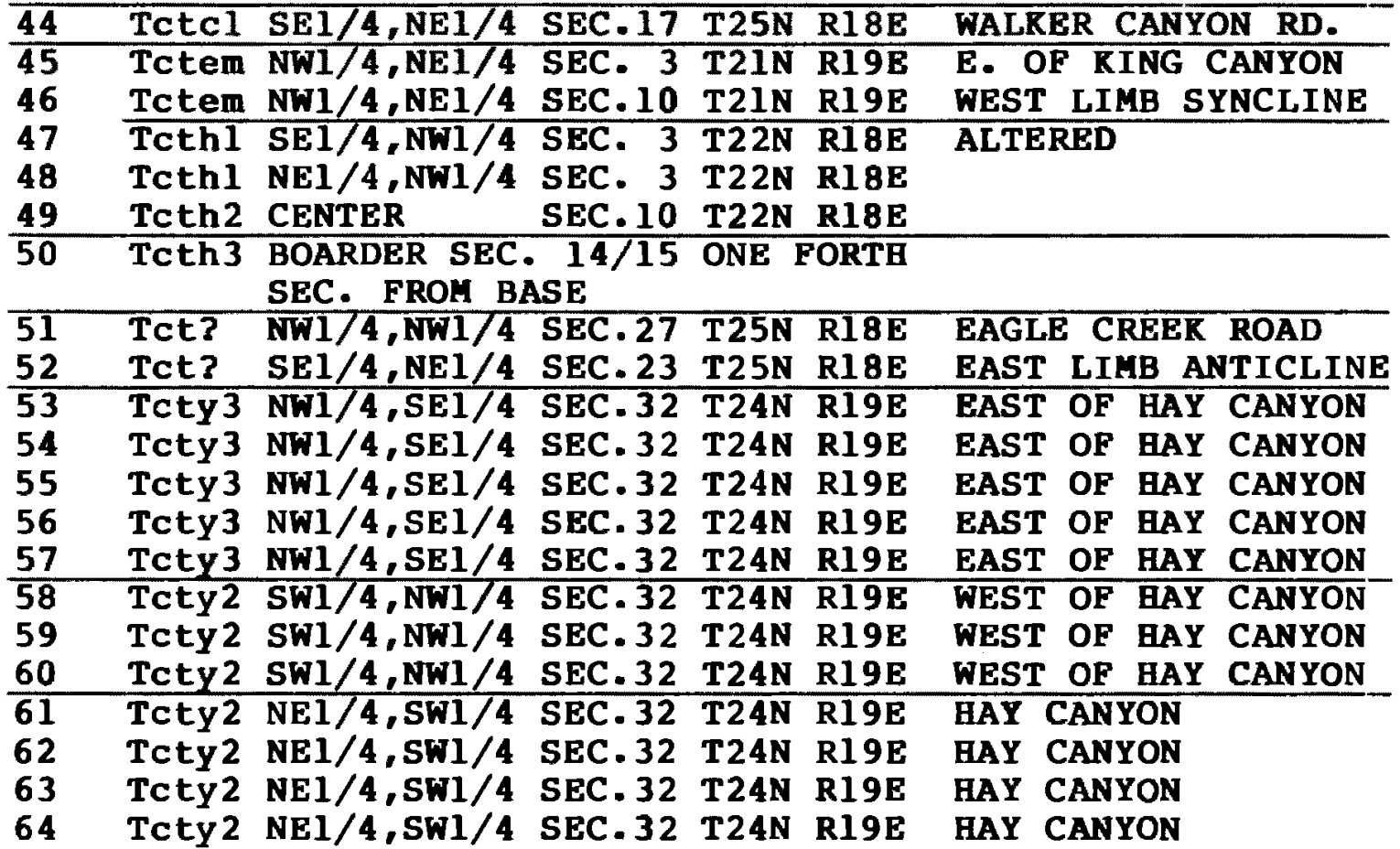


CHEMISTRY OF THE CHUMSTICK TUFES

TUFF OF FAIRUIEH CANYON

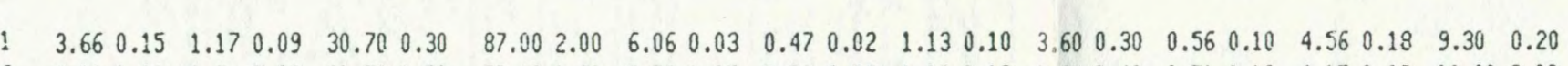

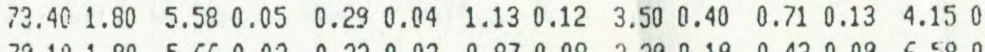
TUFF OF YAXON CAMYNON NEMBER THREE

$\begin{array}{llllllllllllllllllllllllll}4 & 4.74 & 0.17 & 1.61 & 0.11 & 25.00 & 0.30 & 70.90 & 1.80 & 7.11 & 0.03 & 0.49 & 0.02 & 1.09 & 0.10 & 4.30 & 0.20 & 0.62 & 0.11 & 2.94 & 0.17 & 10.80 & 0.30\end{array}$

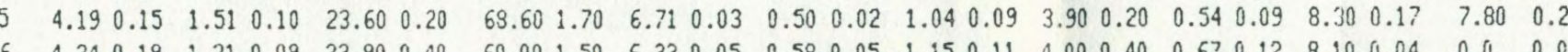
TUFF OF YAXON CAYUN NUMBER TWO

Hif ta la ce Sm eu to to lu sc ci

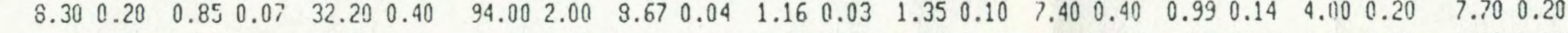

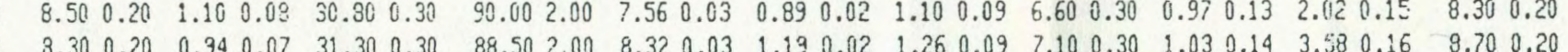

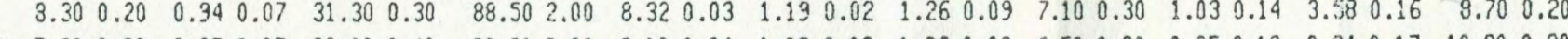

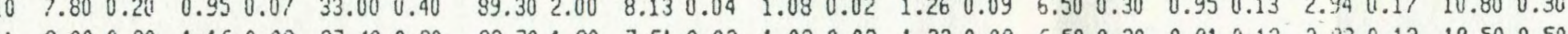
$\begin{array}{llllllllll} & 1.30\end{array}$

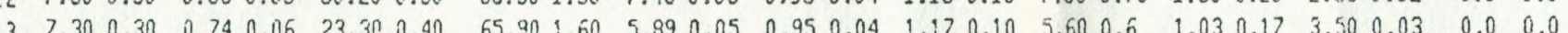

TUFF OF YAXON CANYON NUMBER. ONE

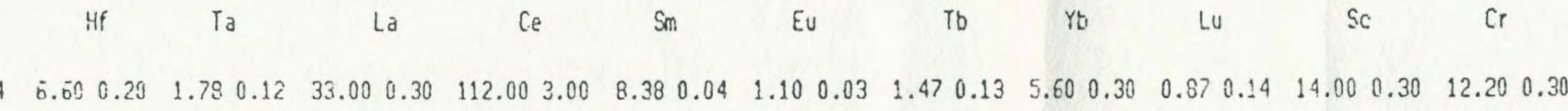

TUFF OF MISSION CREEK NUMBER XNE

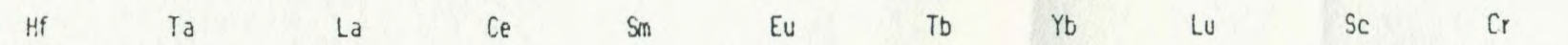

$\begin{array}{lllllllllllllllllllllll}15 & 5.30 & 0.20 & 1.42 & 11.10 & 37.90 & 0.30 & 110.00 & 2.00 & 9.09 & 0.03 & 0.57 & 0.02 & 1.22 & 0.11 & 5.40 & 0.30 & 0.71 & 0.11 & 12.30 & 0.20 & 14.60 & 0.30\end{array}$

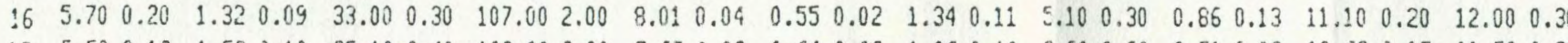

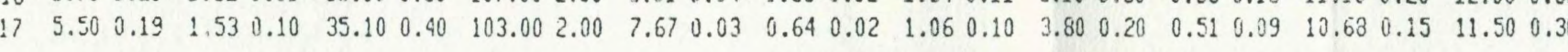

TUFF OF MISSION CREEY, NIMIMER, TWO

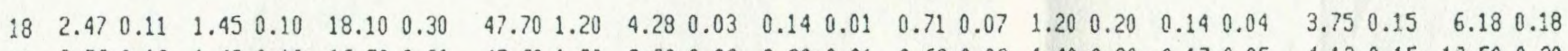

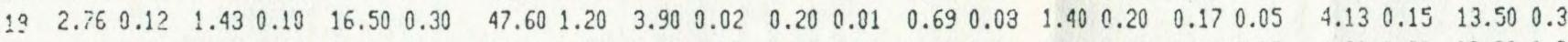

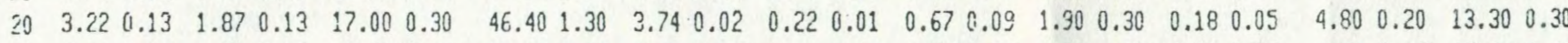

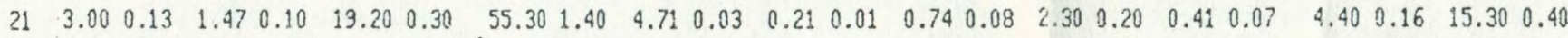

TCt

.99 $0.02 \quad 0.760 .08 \quad 1.040 .08 \quad 0.450 .0 \quad 6.301 .10 \quad 16.100 .40 \quad 1.290 .19 \quad 2260.00200 .00$

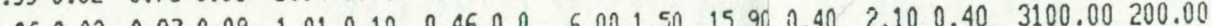

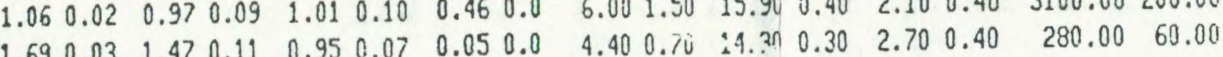
Tcty 3

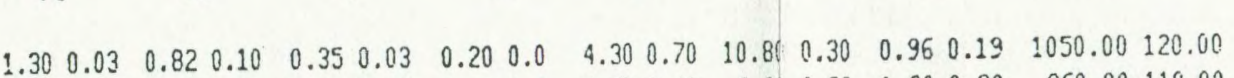

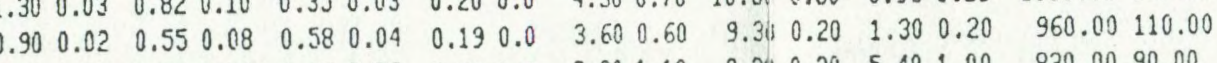

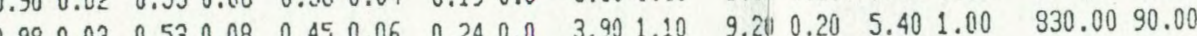
Tcty2

$\mathrm{Fe}$

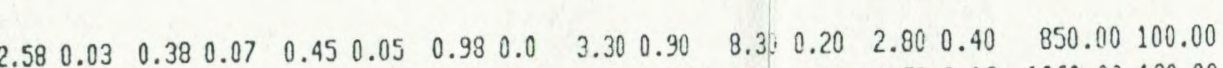

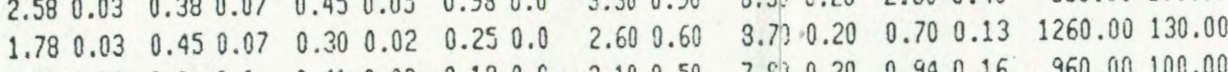

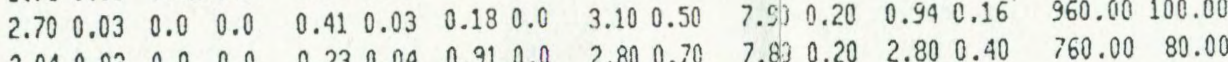

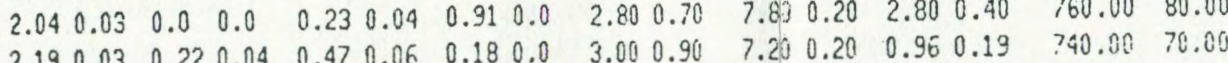

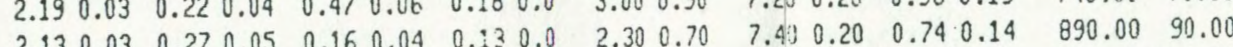

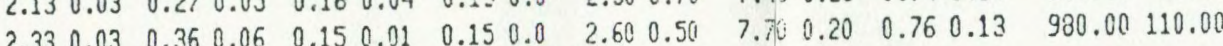
Tcty1

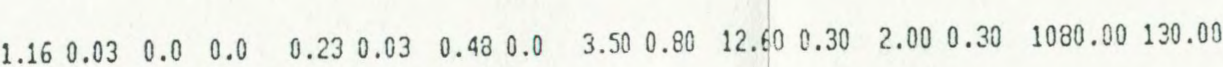
Tctm1

$\begin{array}{llllllll}\text { Fe } & \text { Co } & K & \text { Na } & \text { U } & \text { Th } & \text { Cs } & \text { Ba }\end{array}$

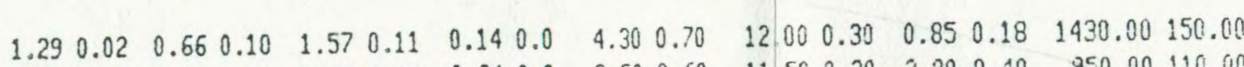

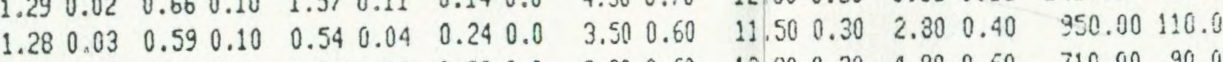

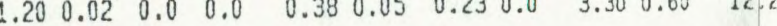
Tetm2

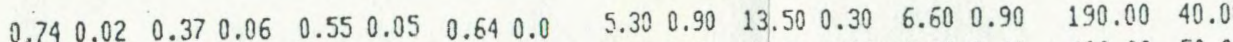

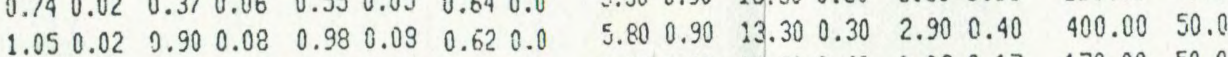

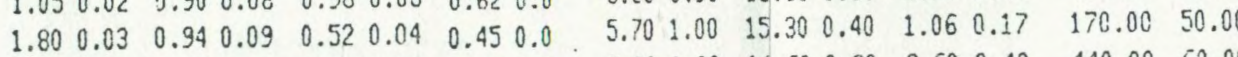

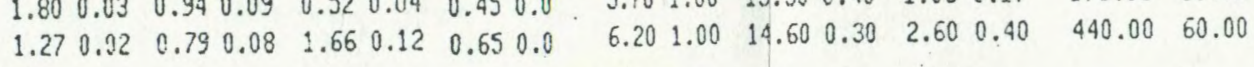

Lef: colums are elemental abundances in ppm except $F e$, Ha, and $k$ which are pct.

20 Al tered to smectite
Right columns are percent error 
CHEMISTRY OF THE CHUMSTICK TUFFS

TUFF OF EAGLE CREEK

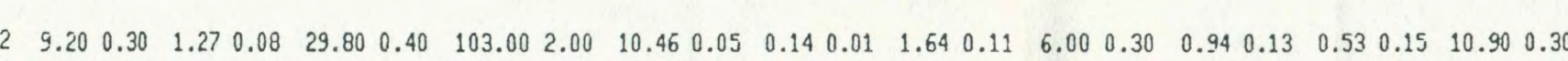

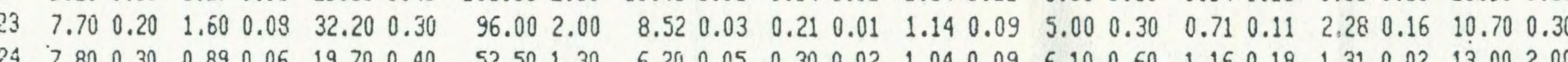

\section{TUEF OF CLAPK CAMTON NUMBER NINE}

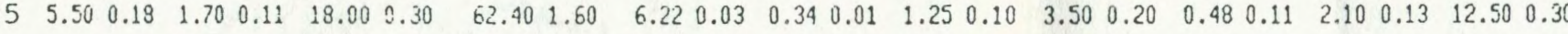

$$
\text { TUFF OF CLARK CAIYON NIMBER EIGHT }
$$

$36 \begin{array}{lllllllllllllllllllllll}5.03 & 0.19 & 1.16 & 0.07 & 11.60 & 0.30 & 34.70 & 1.00 & 4.63 & 0.04 & 0.41 & 0.03 & 1.03 & 0.09 & 3.10 & 0.40 & 0.48 & 0.10 & 2.60 & 0.02 & 23.00 & 4.00\end{array}$

UIFF OF CLARK CANYON NUMBER SEVEN

Hf Ta La ce Sm Eu to

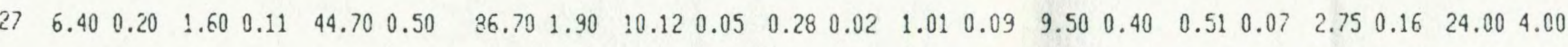
TUFF OF CLARK CAHYON NIMBER SIX

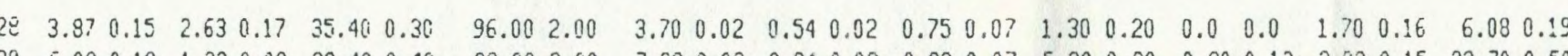

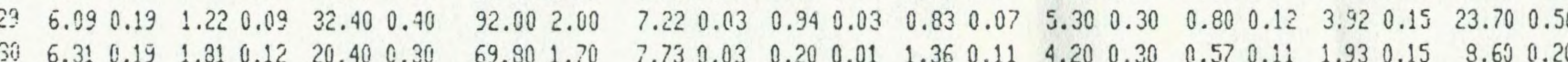

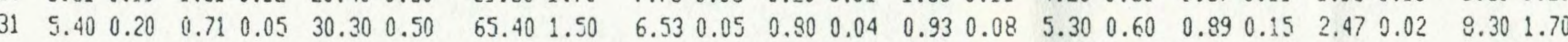

\section{TUFF OF CLARK CANTON NUMBER FIUE}

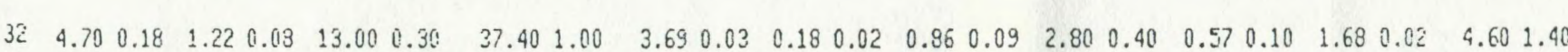

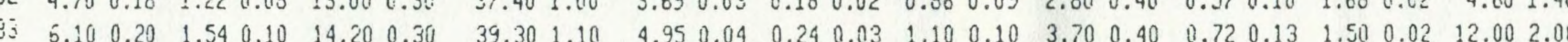

TUFF OF CLAPY. CAMYTON NLMBER FOUR.

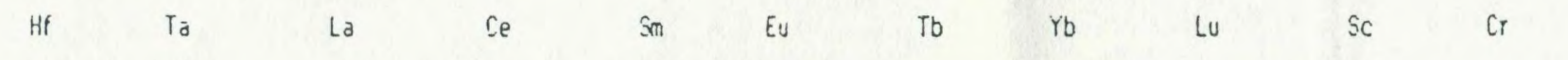

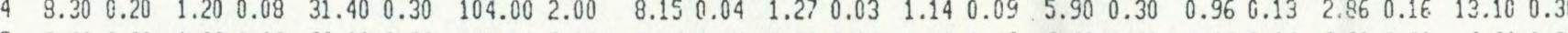

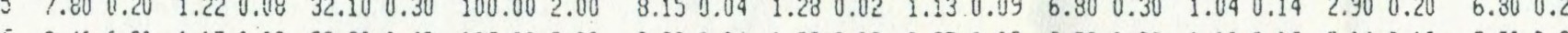

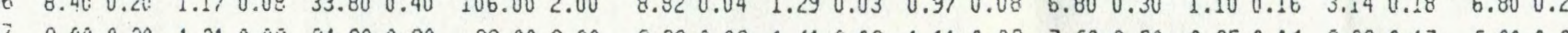

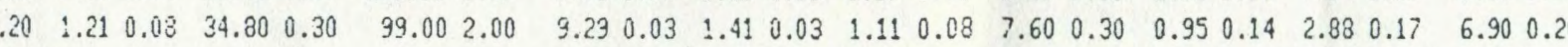
24 Ash claud part of deposit
Tcte

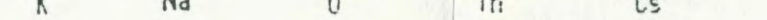

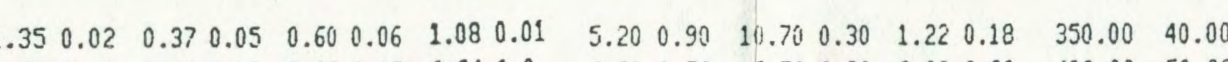

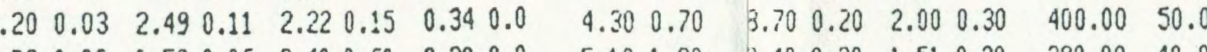
$\operatorname{Tctc} 9$

140.00 rctc8

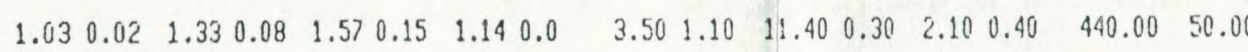
Tctc?

\begin{tabular}{lllll|lll}
$\mathrm{Fe}$ & $\mathrm{C} 0$ & $\mathrm{~K}$ & $\mathrm{Na}$ & $\mathrm{U}$ & Th & cis & $\mathrm{Ba}$
\end{tabular}

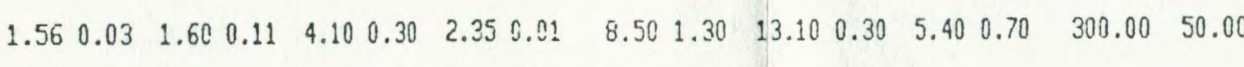
Tctc6

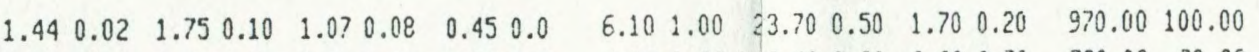

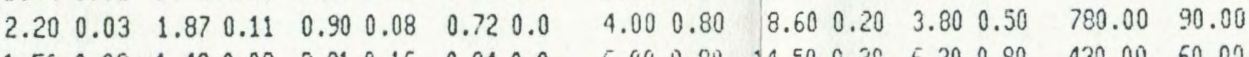

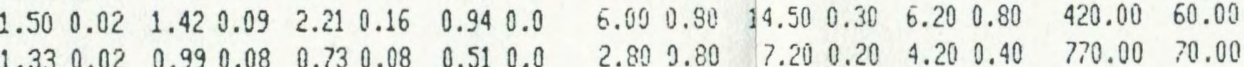
Tctc5

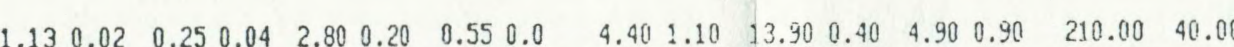

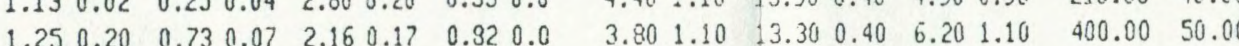
Tctc4

$\begin{array}{llllllll}\mathrm{Fe} & \mathrm{Co} & \mathrm{K} & \mathrm{Na} & \mathrm{U} & \mathrm{Th} & \mathrm{CS} & \mathrm{Ba}\end{array}$

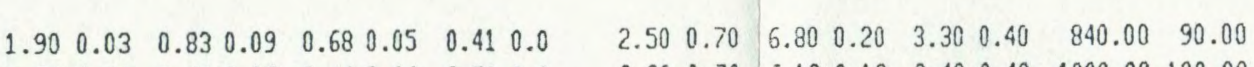

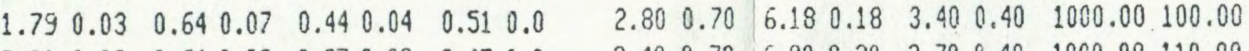

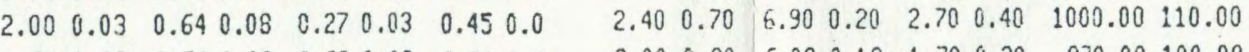

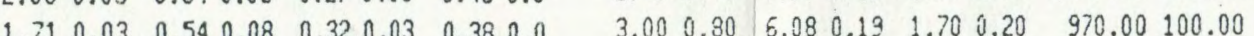


CHEMISTRY OF THE CHUMSTICK TUFFS

TUFF OF CLARK CANYN NMMBER THREE to ce Sm

To $\quad Y$

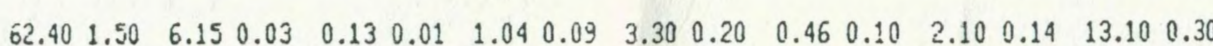
TUFF OF CLARK CONYSN NIMBER TWO

$\begin{array}{lllllllllllllllllllllll}4.97 & 0.15 & 1.59 & 0.11 & 15.40 & 0.30 & 49.30 & 1.30 & 6.09 & 0.03 & 0.12 & 0.01 & 0.69 & 0.05 & 3.50 & 0.30 & 0.62 & 0.07 & 1.96 & 0.02 & 6.30 & 1.60\end{array}$

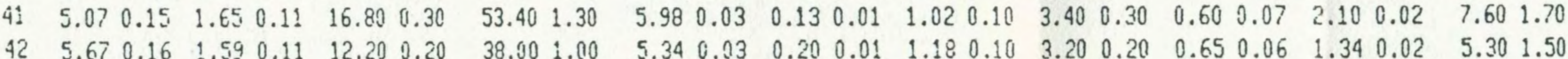

\section{TUEF OF CLAPK CSMYOSI NIMBER ONE}

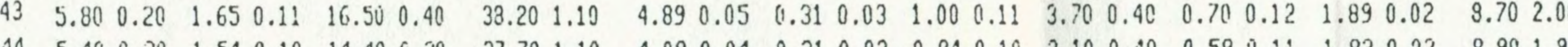

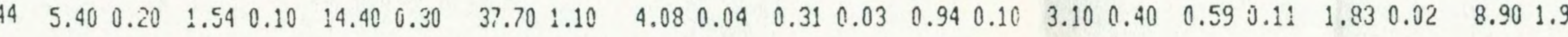

$$
\text { TUFF OF EAST MISSIOS CREEK }
$$

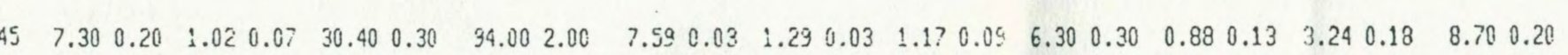

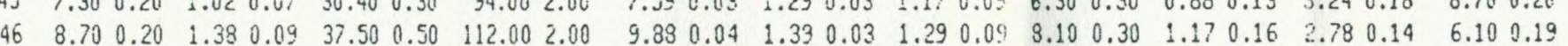

\section{TUEFS OF HORSE LAKE MOLNTAIN}

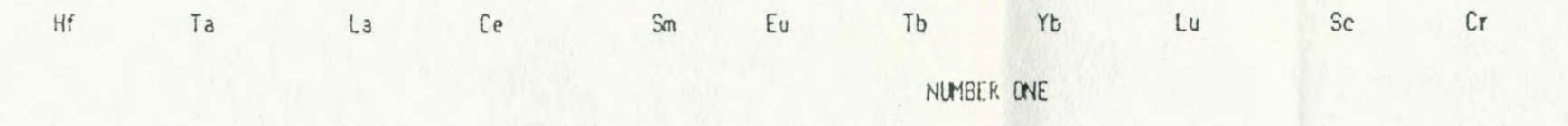

$\begin{array}{lllllllllllllllllllllll}47 & 4.64 & 0.16 & 0.83 & 0.07 & 20.90 & 0.30 & 62.30 & 1.60 & 4.57 & 0.03 & 0.78 & 0.02 & 0.69 & 0.07 & 3.10 & 0.30 & 0.53 & 0.09 & 5.88 & 0.19 & 14.30 & 0.30\end{array}$

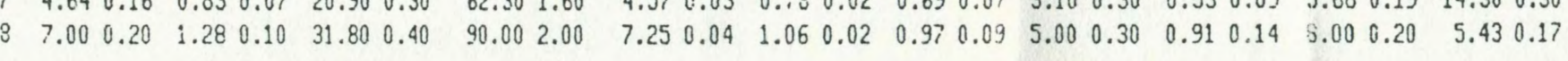

$$
\text { NLMEERR THO }
$$

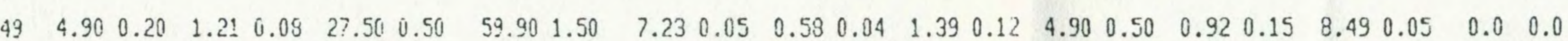

$$
\text { NLMBER THPEE }
$$

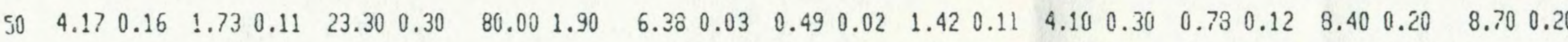
UNAMED TUFF EXPOSURES

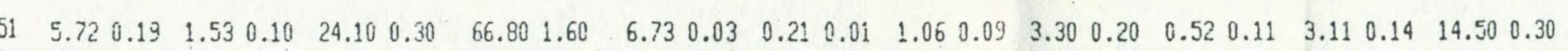

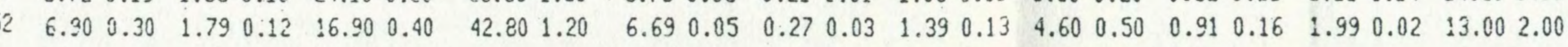

Tctc3

\subsection{0 .10 .0}

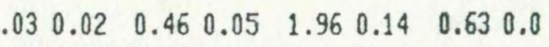

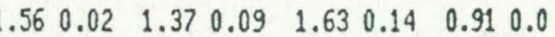
Tctc2

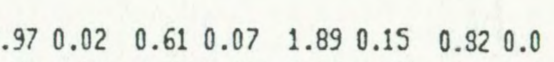

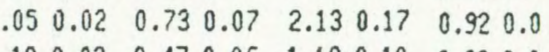
Tctc

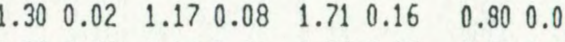
$\begin{array}{llllllll}1.29 & 0.02 & 0.14 & 0.01 & 1.59 & 0.15 & 0.71 & 0.0\end{array}$ Tctem

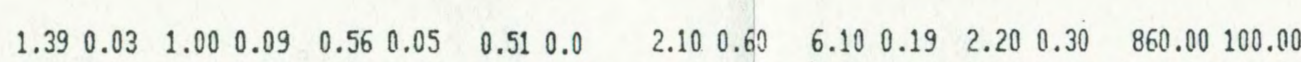

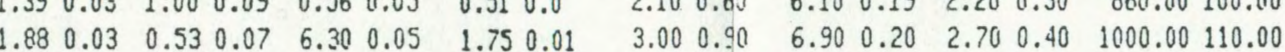
Fe

\subsection{1}

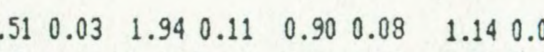
Tcth2

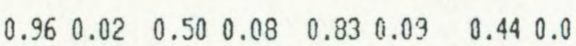
Tcth3

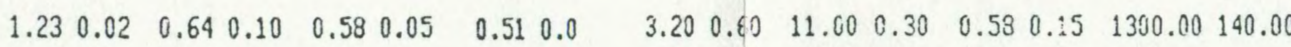
Tatc?

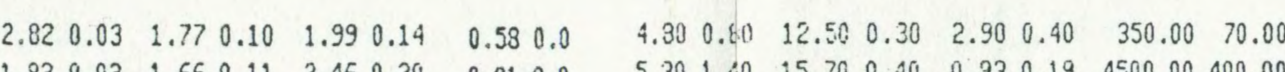

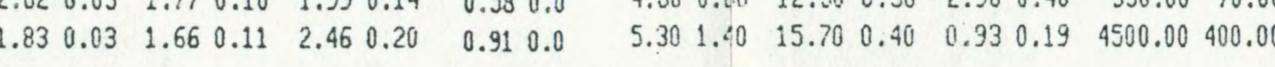

\footnotetext{
47 Al tered 
CHEMISTRY OF SAPPLES TAKEN STRATIGRAPHICALLY THROUGH THE TUFF OF YAXON CAWYON THREE

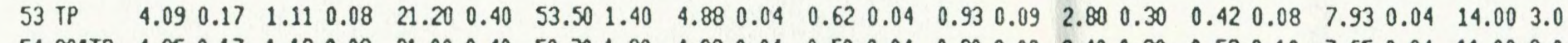

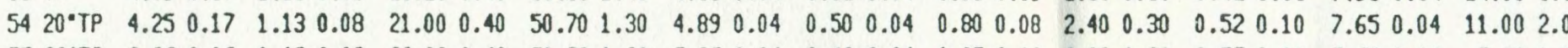
\begin{tabular}{lllllllllll}
55 & 38 \\
\hline
\end{tabular}

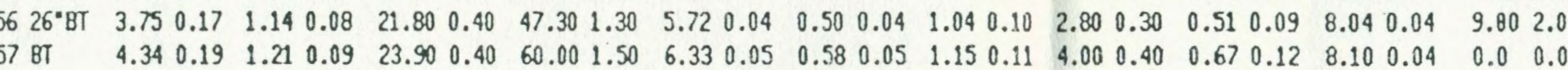

CHEMISTRY OF SAPPLES TAKEN STRATIGRAPHICALLY THROJGH THE TUFF OF YAXCN CAHYON THO

LOCALITY

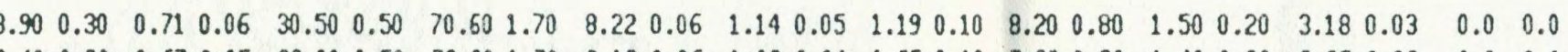

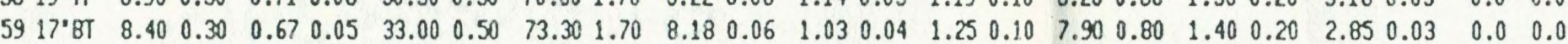

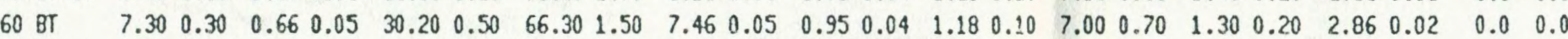
LoCal 1 Tr 2

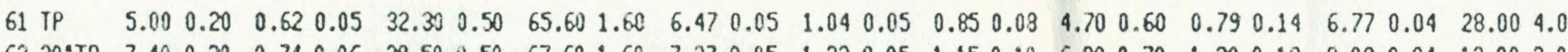

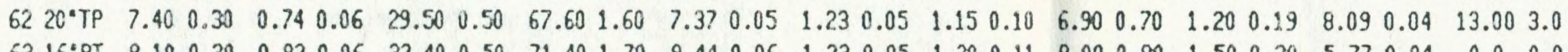

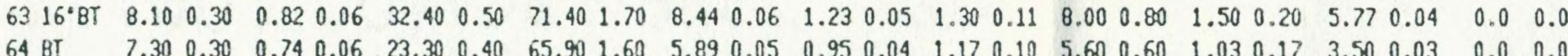

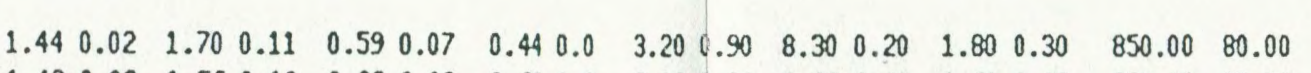

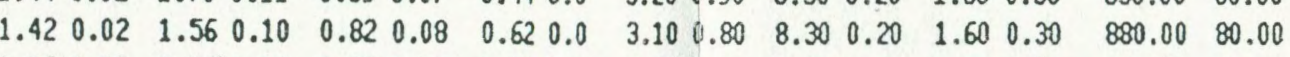

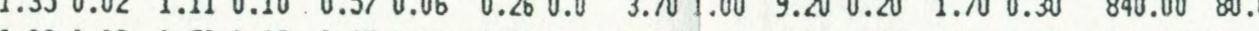

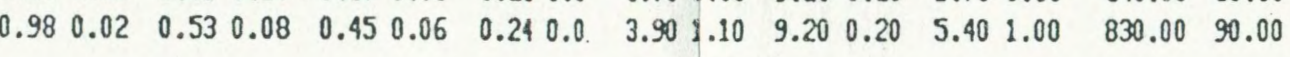

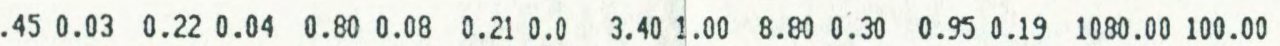

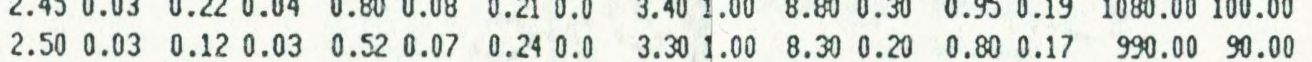

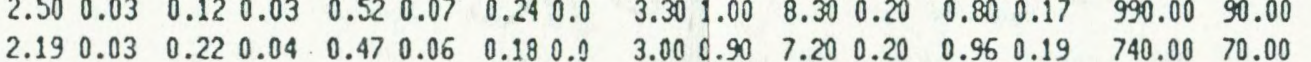

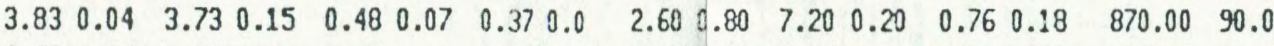

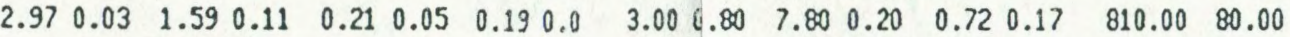

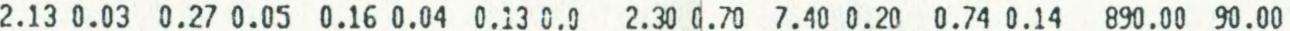


TABLE X

WHOLE ROCK CHEMISTRY

TUFF BED TctCl TctC2 TctC4 TctM1 TctY2

\begin{tabular}{lrrrrrr}
\hline $\mathrm{SiO2}$ & 76.27 & 77.06 & 76.89 & 79.44 & 77.15 & PCT \\
TiO2 & 0.22 & 0.12 & 0.21 & 0.13 & 0.32 & PCT \\
A1203 & 14.48 & 13.53 & 13.82 & 13.07 & 12.92 & PCT \\
& & & & & & \\
$\mathrm{Fe} 203$ & 1.65 & 0.49 & 0.99 & 1.45 & 3.08 & PCT \\
$\mathrm{FeO}$ & 0.05 & 0.80 & 1.29 & 0.11 & 0.44 & $\mathrm{PCT}$ \\
$\mathrm{MnO}$ & 0.01 & 0.02 & 0.03 & 0.01 & 0.04 & $\mathrm{PCT}$ \\
& & & & & & \\
$\mathrm{MgO}$ & 1.20 & 0.64 & 0.72 & 1.25 & 1.42 & $\mathrm{PCT}$ \\
$\mathrm{CaO}$ & 3.38 & 3.71 & 4.91 & 3.68 & 3.77 & $\mathrm{PCT}$ \\
$\mathrm{Na2O}$ & 0.89 & 1.09 & 1.24 & 0.32 & 0.27 & $\mathrm{PCT}$ \\
$\mathrm{K2O}$ & 1.73 & 2.45 & 0.42 & 0.46 & 0.50 & $\mathrm{PCT}$ \\
$\mathrm{P2O5}$ & 0.05 & 0.04 & 0.08 & 0.04 & 0.03 & $\mathrm{PCT}$
\end{tabular}

$\begin{array}{lllllll}\text { TOTAL } & \overline{99.93} & \overline{99.95} & \overline{100.6} & \overline{99.96} & \overline{99.94} & \text { PCT }\end{array}$ Percentages recalculated after water removed

\begin{tabular}{|c|c|c|c|c|c|c|}
\hline $\mathrm{Ba}$ & 542 & 280 & 1125 & 786 & 1118 & PPM \\
\hline Co & --- & -- & -- & --- & --- & PPM \\
\hline $\mathrm{Cr}$ & 8.1 & 6.1 & $4 \cdot 1$ & 4.0 & 5.1 & PPM \\
\hline $\mathrm{Cu}$ & 8.2 & 6.4 & 7.3 & 9.1 & 13 & PPM \\
\hline $\mathrm{Li}$ & 34 & 32 & 30 & 22 & 45 & PPM \\
\hline $\mathrm{Ni}$ & 5.6 & 2.8 & 9.8 & -- & 5.6 & PPM \\
\hline $\mathrm{Rb}$ & 109 & 98 & 19 & 46 & 19 & PPM \\
\hline $\mathrm{Sr}$ & 5162 & 2054 & 2731 & 1783 & 4876 & PPM \\
\hline $\mathrm{Zn}$ & 85 & 77 & 118 & 73 & 123 & PPM \\
\hline SiO2 & 68.19 & 69.44 & 66.51 & 69.01 & 67.00 & PC \\
\hline TiO2 & 0.20 & 0.11 & 0.19 & 0.12 & 0.28 & PC \\
\hline Al 203 & 12.95 & 12.20 & 11.96 & 11.36 & 11.22 & PCT \\
\hline $\mathrm{Fe} 203$ & 1.48 & 0.45 & 0.86 & 1.26 & 2.68 & PCT \\
\hline $\mathrm{FeO}$ & 0.05 & 0.73 & 1.12 & 0.10 & 0.39 & PCT \\
\hline MnO & 0.01 & 0.02 & 0.03 & 0.01 & 0.04 & PCT \\
\hline MgO & 1.08 & 0.58 & 0.63 & 1.09 & 1.24 & PCT \\
\hline $\mathrm{CaO}$ & 3.03 & 3.35 & 4.25 & 3.20 & 3.28 & PC \\
\hline $\mathrm{Na} 2 \mathrm{O}$ & 0.80 & 0.99 & 0.51 & 0.28 & 0.24 & PC \\
\hline K20 & 1.55 & 2.21 & 0.37 & 0.40 & 0.44 & PC \\
\hline $\mathrm{H} 2 \mathrm{O}+$ & 4.87 & 4.94 & 6.85 & 6.55 & 6.77 & $P C$ \\
\hline $\mathrm{H} 2 \mathrm{O}-$ & 5.99 & 5.37 & 6.63 & 7.39 & 6.32 & $\mathrm{PC}$ \\
\hline P205 & & 0.04 & 0.07 & 0.04 & 0.03 & \\
\hline TC & 100.25 & 100.48 & 99.98 & 100.81 & 99.93 & \\
\hline
\end{tabular}

